\title{
At Home with a View Exploring notions of landscape
}




\section{At Home with a View}

Exploring notions of landscape

$$
\text { by }
$$

Hester Blyth Borren

A 120 point thesis submitted to the School of Architecture and Design, Victoria University of Wellington, in partial fulfillment of the requirements for the degree of Master of Architecture (Prof.)

\section{Victoria University of Wellington}

2012 


\section{Abstract} and value of a view of landscape with respect to the interior of New Zealand houses. It explores the all-or-nothing manner in which contemporary architecture presents surrounding scenery. Through a translation of New Zealand landscape paintings, it presents alternative approaches for connecting the interior and exterior of a house in such a way that can enhance both the experience of a view and a house. In doing so this thesis contends that artistic themes and techniques can enrich views of landscapes, especially of nature, through the architecture of New Zealand houses.

This thesis employs three research approaches to achieve its aim. The first research section, a literature review, provides an examination of historical and contemporary western attitudes towards a view. This confirms that much of western society has learnt to appreciate and benefit from, a view, and that the nature of people's response is deeply ingrained. The second section focuses on domestic views in both international and Wellington houses. Each study is analysed to gain understanding of the design strategies in respect to architectural presentations of a view. The last section pursues a more integrated designresearch approach, separated in two parts. Firstly, it explores a possible connection between the artistic treatment of landscape paintings and architectural treatments of houses. Four spaces are presented as studio residences for artists, focusing on four 
very different characteristics of land. Secondly, two further house designs are developed which employ techniques produced from the first design part as well as research from the previous sections. It aims to present two opposite spatial approaches to a depiction of surrounding landscape in an architectural design one that presents a single view to look at and one that presents a series of views to engage with.

This final design section explores the above contention It presents how a connection between landscape art and architecture can offer guidance to the way in which a view is experienced from New Zealand homes. This is achieved on a theoretical as well as practical level, generating a range of techniques for further exploration. 


\section{Acknowledgements}

I would like to acknowledge Frances Blyth, my 'editor-in-chief' for the unconditional support and advice throughout this year and the years previous - from near or afar.

I would also like to thank Peter Parkes for the guidance he has provided throughout this year. 
Introduction

\section{Contents}

A definition

Problem statement

Aims and objectives

Research approach

Chapter 1: A brief history of European attitudes

to landscape in art, architecture and literature

Classical Times

Middle Ages

Renaissance

Picturesque movement

Chapter 2: A brief history of domestic windows and the influences of technology and modernism within architecture

A window

Modernism in architecture

Chapter 3: A view in the twentieth century

A theory of vision

Modern art

Psychology of a view

Chapter 4: A New Zealand context

New Zealand housing

The real estate market

New Zealand landscape

Chapter 5: Five international case studies

La Petite Maison

Moller House 
Farnsworth House

Slow House

Picture Window House

Chapter 6: Three local case studies

45 Orangi Kaupapa Road

58 Ponsonby Road

Marine Drive

Chapter 7: Design argument

Chapter 8: Site description and analysis

Chapter 9: Design, part 1: Artist studies John Gully

Rita Angus

Gerda Leenards

David Barker

Chapter 10: Design, part 2

House One

House Two

Chapter 11: Conclusions and discussion Research scope and summary

Thesis contention

Research aims, outcomes and future development

List of Figures

Bibliography

Appendix 1: Diagrams

Appendix 2: Human Ethics Approval 


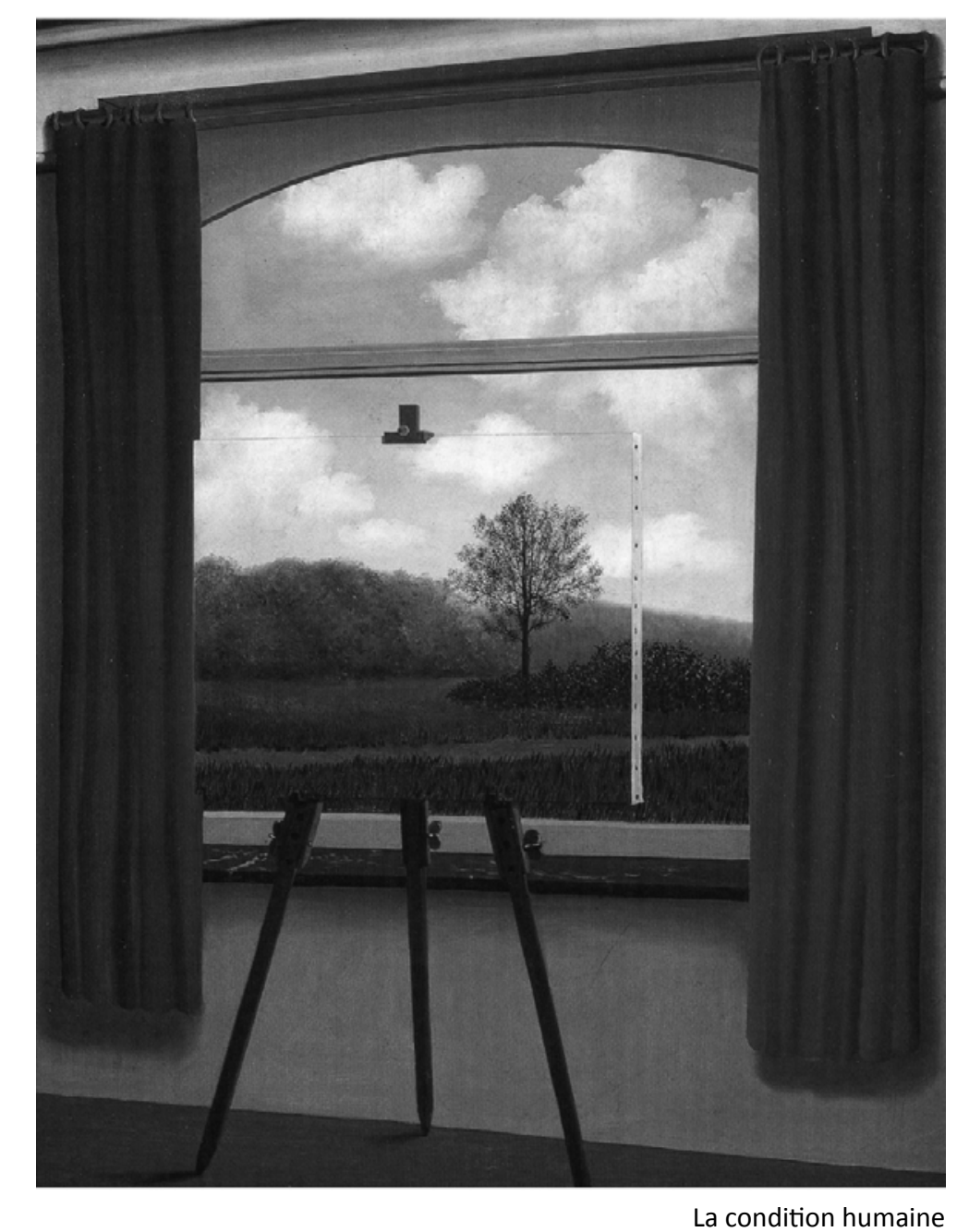

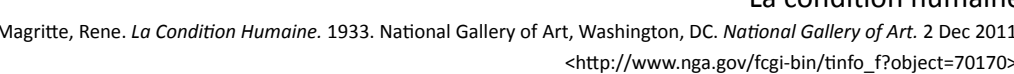




\section{An introduction}

\section{View: A definition}

"A sight or prospect of some landscape or extended scene;

an extent or area covered by the eye from one point"

(Oxford English Dictionary, “View, N”)

The etymology of the word 'view' dates back numerous centuries. Although it originates from the French verb voir, to see, its current meaning has existed since the beginning of the seventeenth century. Formally used to describe a "formal inspection or survey of lands", the word view has transformed over the centuries into a more general visual phenomenon (Oxford English Dictionary, “View, N”).

Today there are two main uses of the noun: a visual experience, the basis of this thesis, and a view as a mental construct, a thought or belief. Because the act of seeing cannot be separated from the interpretations of human brains, perception plays a large part in the way people view their surroundings.

While noting there is no singular view or view type in existence, the word 'view' will be used as it encapsulates the meaning of visual sight from one vantage point. For this thesis it refers largely to a visual experience inside a residential dwelling to an external landscape beyond. 


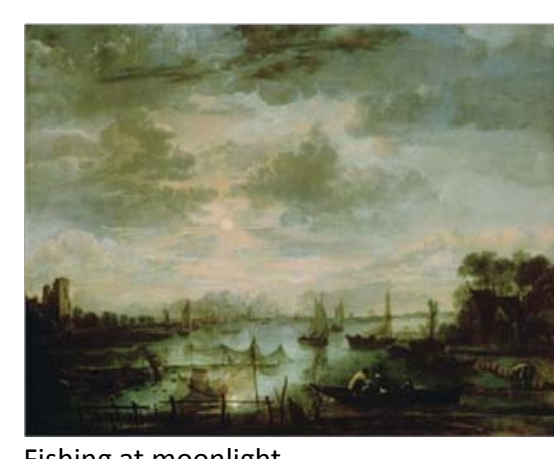

Fishing at moonlight
Neer Aert van der Fullandschof Neer, Aert van der Flußlandscchaft Mit Schiffen Bei Mondschen
1670. Kunst Historisches Museum, Vienna. Kunst Historisches 1670.0 Kunst Historische 1 she
Museum. 24 Nov 2011. gallery/selected-masterpicess/>.
Three key words in the definition above have significant roles in the following chapters: landscape, extended, and the notion of a view from one point

The Dutch word landschap was translated into the English term landscape at the end of the sixteenth century. This occurred with the arrival of paintings depicting Dutch countryside, some of the first art in Europe which focused on a landscape as the subject (Crandell). The association with representation as well as a countryside has remained with the word landscape ever since (Pound, Frames on the Land). Today the terms 'landscape' and 'scenery' generally refer to some form of depicted natural environment, especially a countryside or area of relative wilderness.

An appreciation of a view, as understood today, has only existed in the western world since the seventeenth century. Influenced by the eighteenth century picturesque movement, this enjoyment is based on a pictorial notion of nature; the western world views land not dissimilar to an observation of a painting. Research for this thesis reveals that within this visual culture, people objectify the surroundings, viewing the land as an object of pleasure or fear, yet land is always seen as separate or disconnected from a viewer. This separation generates a distance, a form of safety barrier, between a human spectator and their surroundings. Through the urbanisation of towns, citydwellers' interaction with nature has decreased, reinforcing the visual value of landscapes and scenery.

\section{Problem statement}

Over the last four hundred years western society's attitudes towards landscape have evolved, in response to both cultural and technological developments. Within the last century, an international shift has occurred in the value placed on a house which offers its occupants a view over the surrounding landscape. The introduction of a view as a priority in domestic architecture in the twentieth century has led to a growth in houses which, often above all else, provide a platform for a view.

Central to this thesis is the argument that such houses prioritise a dominating view at the expense of an overall design. The following research suggests that the way that these glass pavilions offer an entirely visual expression of landscape removes any potential for people to seek a more intimate connection with the surrounding scenery. They are denied the full potential for an emotive visual experience.

This thesis looks at this global phenomenon in a New Zealand context. It is not uncommon for New Zealand real estate agents to sell a property based on the appeal of a property around views from the house. However, there has been little analysis of New Zealanders' relationships with a view (Collins and Kearns). Architects oblige those clients who prioritise a view with little or no questioning of a role of a view and how best to deal with it.

New Zealand has had a strong affiliation with European values. Its European past offers the opportunity for an understanding of how views have been regarded by people over time. While domestic architecture existed in New Zealand before European colonisation, a view as an observation of landscape was not a notion that seems to have existed before the arrival of European settlers. Maori did not separate themselves from their surroundings and did not consider the value of viewing it for pleasure from a distance (Pound, Frames on the Land). European settlers brought European values and techniques; they brought glass technology and an appreciation for observing land from the safety and distance of a removed spectator.

Internationally, there has been little research during the twentieth century on the roles of a view in house design and 
there appears to be little understanding of changes in attitudes to a view by the design profession or clients. In order to challenge current practices, this thesis seeks a better understanding of the roles of a view and its historical context. Using this background an attempt is made to explore how an architectural design that produces a visual outlook can express a more balanced relationship between viewer and view. A balance is sought through an integrated or holistic approach to a design, where a view is an integral part of both building and site.

\section{Aims and objectives}

The aim of this thesis is to gain an understanding of the roles of a view and its relationship to interiors of New Zealand houses. This aim stems from a personal reservation in relation to houses as 'viewing platforms'. This thesis endeavours to offer a range of possible outcomes that better unite the design of an interior and the manner in which it frames a view. To achieve this endpoint, the objectives are:

- To gain a wider historical, cultural and theoretical

understanding of the context for the role of a view.

- To understand the construction and alteration of New Zealand houses during the course of the twentieth century with respect to a view.

- To understand changes in attitudes in both the design profession and the general public with respect to a view over the one hundred year period.

- To apply both a theoretical and practical understanding of the relationship between a viewer and a view through design.

\section{Research approach}

There are three sections within this research methodology. The first is an historical examination of a view through literature based research. The first four chapters of this thesis offer an outline of history which has generated contemporary notions of a view. This section highlights significant connections to other areas of study within and outside of the architecture profession. This research helps align a view to cultural and technological movements that have occurred prior to and during the twentieth century within both an international and New Zealand context. It offers opportunities to challenge new and old beliefs through an interdisciplinary study. It attempts to provide a detailed background for the analysis of Chapters five and six.

Chapters five and six represent section two. They comprise of two sets of case studies which aim to better understand the values western society places on a view and existing strategies of deployment in a selection of international and Wellington houses. In an attempt to understand their use and relationship to their surroundings, an analysis of five well-known international houses is presented in Chapter five. These houses have been chosen for the manner in which views have been considered and designed for. This research focuses solely on the relationship the house has to its view and the theoretical underpinning which led to this rapport.

A similar study in Chapter six analyses three Wellington based case studies. Attitudes towards landscape within these houses are illustrated through a series of interviews, offering a more practical understanding of the perspective of both architect and inhabitants.

Based on research collected from both a review of literature and analysis of the case studies, the final chapters present an integrated design-research section. This includes a translation 
of themes used by four New Zealand landscape artists into an architectural context, in order to consider the links between artistic and architectural rendering of landscape. The final design stage draws on all the previous research, and aims to present two opposite approaches to the depiction of surrounding landscape in an architectural design. Finally, the last chapter reviews the body of research examined within this thesis. It reflects on the design arguments and outcomes, and proposes further development in several areas. 


\section{Chapter 1:}

\author{
A brief history of European attitudes to \\ landscape, as reflected in art, literature \\ and architecture
}

"We have defined and judged nature on the basis of its conformities with pictures"

(Crandell 5).

The following chapter is a selective overview of European art, literature and architecture from Classical times until the eighteenth century, as it relates to the development of western thinking about land and people's relationship to views of landscapes. It has become apparent in this investigation that a history of a view is connected to attitudes towards landscape. This is a relationship which has its origins in fundamental cultural and religious beliefs about a human's place and role in the world.

This research will attempt to demonstrate a parallel between the evolution of western attitudes to land and artistic representations of landscape, demonstrating that both have been significantly influenced by the development of artistic genres and techniques. The notion of a view as understood today is a direct descendant of artist development.

It is necessary to understand the evolution of western thinking about a view as New Zealand attitudes are heavily influenced by historical and cultural ties to Britain and Europe. It should be noted that while historically New Zealand architecture has been influenced mostly by European architectural ideals, 
contemporary New Zealand architecture looks as much to America and the other parts of the world for inspiration.

The transformation in attitudes described in this chapter does not look beyond a western context. In countries like China, landscape has been a subject of observation in art and literature since the eighth century (Tunnard).

\section{Classical Times}

This research owes much to Gina Crandell and her book, Nature Pictorialized, which presents a history of European relationships with nature (Crandell). Her discussions begin in Ancient Greece. During this time, attitudes towards landscape were based on associations between land and worship of deities. The placement and orientation of Greek temples was relative to their Gods whom the temples celebrated. Temples were not built to house people, but to honour the particular god/goddess through the relationship between built form and characteristics of its setting. The qualities of the external environment were to be experienced, not observed (Scully).

This was not the modern relationship of a human spectator observing the landscape; the Greek relationship to land was as a living sculpture. The form and depth of a temple and its site were understood through movement in and around the structure (Crandell). Olympia "was designed sculpturally: the worshipper would not have seen the whole at once. Instead, it was necessary for the observer to follow a designed sequence, revealing aspects of the site in a cumulative, sculptural manner" (Crandell 26). The temple was not separated from its surroundings; the surrounding land was understood through interaction with its architecture.

Several aspects of Classical design and culture incorporated notions of land similar to those in western society today. The marble columns which ran the perimeter of many Greek temples provided frames of view of surrounding landscape (Crandell). Many sites were at the top of high mountains generating "a sensation of physical and spiritual dominance over the landscape" (Crandell 24). These temples were placed at this height to pay homage to sky gods, yet their distance from the majority of surrounding land empowers viewers as they look beyond the temple.

The popularity of theatre in the Roman and Hellenistic period shows a further development in the notion of landscape. Theatre was a way of describing an ideal relationship with the gods and therefore the ideal way to live. Theatre offered a scenario similar to a painting, where a stage is viewed by a central spectator. A stage separates the audience from the scene, and as most Roman theatres were held outside, the scene was of nature, sometimes enhanced by a painted fresco acting as a back drop ${ }^{1}$.

The landscapes depicted in Roman frescos were the subject of these works of art. Research will show later in this chapter that these depictions had more in common with seventeenth century landscape painting than anything in the many centuries in between (Tunnard).

Roman and Greek treatment of landscape in art and literature was not unusual. This can be seen in domestic murals of the time, in references in staged theatre, and in poetry and other literature. It is clear that notions of land and landscape were topical throughout the Classical period. However, over future centuries, this focus was to disappear, and only find a revival in more recent times.

\section{Middle Ages}

Development from Classical times to the Middle Ages saw a significant transformation from admiration of land to a form of
${ }^{1}$ Two staging conventions were developed during this era to give definition to the staging of plays: the use of a coulisse and also columns and pilasters. Gina Crandell, Nature Pictorialized (Harrisonburg, Virginia: John Hopkins Universtiy Press, 1993). These painted or physical frames were the equivalent of the modern window, separating a scene from its spectators and defining the physical parameters of a stage.

A coulisse is a framing device whereby two wings generate a corridor through the central stage. It is a concept later seen in eighteenth century landscape design, with the placement of trees along the edge of an outlook to frame an area in the distance.] 

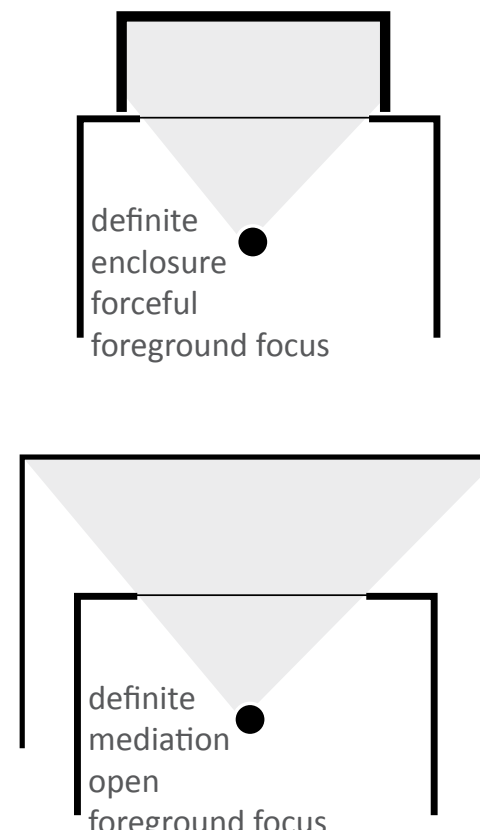

foreground focus

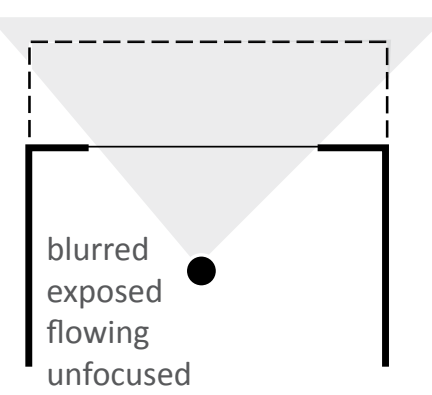

Figure 1.1: Enclosing view fearful reverence. The purpose of art, literature and architecture in the middle Ages was to encourage and demonstrate religious faith; western society's close connection with nature had disappeared. Art depicted biblical stories, and its landscape, which became stylised, was only a background to a biblical event. Landscapes were reduced to objects familiar and understandable to the painter. For example, mountains, if drawn at all, were painted as though constructed of stones (Crandell).

In a technique derived from earlier stylised classical paintings, natural settings were replaced by abstracted backgrounds copied from multiple sources. This left the painting devoid of any real association with its depicted setting.

During this period there was little recognition of earthly pleasure. Land was for work not admiration, as reflected in garden design in this period. High walls were placed between a garden and the surrounding land, producing a boundary of safety and confinement between man and the outside world (Crandell).

Despite this move away from a balanced relationship with nature, the development of techniques and practices in art continued to advance in the Middle Ages. In particular, this period saw the beginning of painting with depth, leading ultimately to the fifteenth century creation of perspective.

\section{Renaissance}

The Renaissance period, a time of discovery of new lands, was also a time of major technological development. Linear perspective, introducing an unprecedented depth and reality into painting, was developed during this period, leading to a move away from stylised translations of nature. The realism produced by this new convention allowed a more naturalistic depiction of land. The earlier fear was no longer apparent, and a beauty within nature was represented through the physical landscape.

Alberti, one of the inventors of this new scientific practice wrote in Della Pittura, "let us always take from nature what we wish to paint and we will always fashion the most beautiful things" (Tunnard 40). This highlights the selective notion within naturalistic painting that existed in Renaissance landscape art. As the Renaissance painter's skill with linear perspective improved, the illusion of reality within paintings grew.

This period also saw a move in art towards the inclusion of interior scenes. Many of the landscapes painted in this era were depicted as "outside", beyond some boundary or separation from interior foreground characters. During this time there were significant advancements in the formulation of nature in paintings, nature being still a background to religious compositions. The subject of art during the Renaissance remained a religious venture. Paintings were used to interpret and convey religion, never to admire the commonplace notion of "earthly things" (Crandell 73).

In the seventeenth century, due to a cultural shift away from mysticism and religion to scientific process, land became considered worthy as a subject of the painting. Two artists have been hailed as the instigators of this shift: the French artist Claude Lorrain and the Italian, Salvator Rosa (Crandell).

Paintings of this time depicted a form of model landscape "wood opened by pastures, coulisse for achieving atmospheric distances, topographic relief, and the presence of water...the pastoral ideal" (Crandell 95). Landscape architects of the time mimicked these techniques to remodel English landscape to recapture the ideal offered in these paintings. 


\section{Picturesque movement}

The meaning of the word 'picturesque', "in the manner of painters", or "picture-like" was used to describe an architectural and landscape movement born out of the developments described above (Macarthur 4). Derived from eighteenth century idealistic attitudes towards landscape, the picturesque approach remains a western tradition both in the consideration and representations of nature.

Picturesque design is generated through a composition of frames, creating visual distance, irregularity and variety. This practice led to the construction of eighteenth century country estate houses with a new set of priorities. Seventeenth century British buildings and gardens were concerned with symmetry and geometry, with little consideration of the surrounding landscape in their placement and orientation. The picturesque offered

"an alternative to symmetrical placement of buildings, the orientation of windows towards site features. While this idea placed emphasis on the view from inside, it also resulted in site changes, forcing the building to accommodate itself to the site resulting in irregular, "picturesque" forms and combinations that would not have otherwise occurred" (Crandell 136). recognised in the eighteen and nineteen centuries, each depicting very different notions of the land: the ideal, the sublime, the picturesque and the topographic. The ideal can be seen to represent beauty picturesave the rustic and pleasant, and

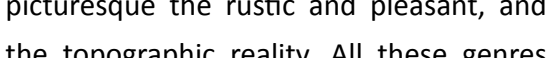
the topographic reality. All these genres still had some kind of artistic licence, "though the painter has no right to add a magnificent castle, he may shovel the earth about him as he pleases... he may pull up a paling or throw down a cottage". Francis Pound, Frames on the Land (Auckland: William Collins Publishing Ltd, 1983).

The picturesque reversed the role of a building as an object of observation, to a building as a vantage point for observation. It broke down rigid rules of proportion within a building to accommodate new relationships with the surrounding land.

During eighteenth century art there was a move away from an idealised landscape to one of romantic vision ${ }^{2}$. The subject became simple and familiar, such as an old cottage, a tumbling down fence, a twisted old tree and grazing farm animals. The placement and control of the composition of these forms became as important as the objects in themselves (Abbott, Stephenson and Ruru). In this way, the picturesque, by synthesising nature, removes the reality of human intervention. The human contro behind picturesque design is hidden through naturalistic expression (Herrington).

The picturesque movement first offered spectators more than a passive and fixed position. The picturesque spectato was invited to travel and participate with their surrounding landscape ${ }^{3}$ (Herrington). At the time, it was suggested that only people of a frail disposition should view the world from indoors as "the variety and surprise that accumulate when walking" far outweighed a stationary position (Isenstadt, "Four Views, Three of Them through Glass" 234).

This new-found interest in landscape and countryside had a wideranging effect, which can be seen in the extensive description of nature in all forms of literature of the time. "Poets infused their landscapes with values which transform the actual picture seen" (Tunnard 48).

By the end of the eighteenth century, landscape had become a subject worthy of consideration in art and literature and a resource to be admired and preserved.

\section{Conclusion}

${ }^{3}$ Landscapes were popular amongst the wealthy middle and upper classes at the time. The picturesque "required a civilisation where men were sufficiently at leisure in the natural world to enjoy the view". Sandy Isenstadt, The Modern American House (New York: Cambridge University Press, 2006) 198. Tours and trips were taken by the wealthy to experience England's grand estates and countryside districts, an early example of modern-day tourism

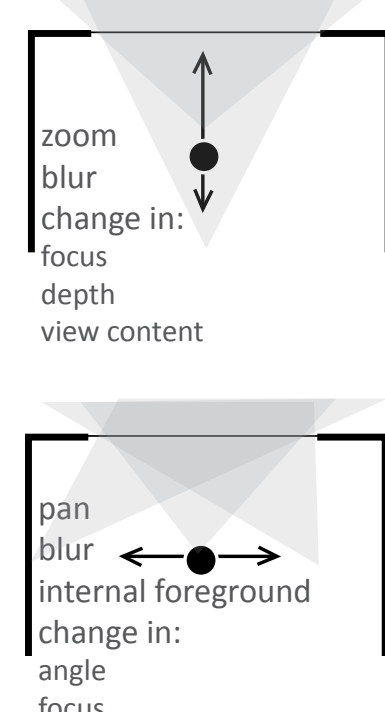
the Classical era to the development of the picturesque style demonstrating changing relationships with landscape and the influence of technical developments of European art has had on it. The chapter builds a foundation for further detailed historical research in the field of landscape, architecture, design and art. In Chapter two a historical examination of a view will continue into the twentieth century, focusing on developments in window technology and the influence of modernist ideals.

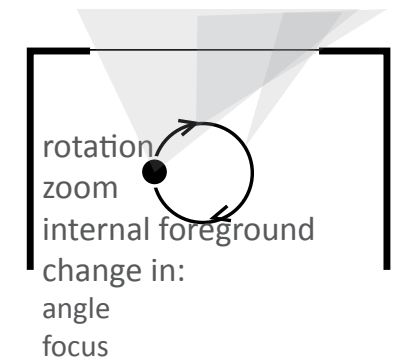

Figure 1.2: Moving viewpoint 


\section{Chapter 2:}

A history of domestic windows and the influences of technology and modernism within architecture
"The window provides these same factors of foreground detail, framing and layered distance and can therefore be seen as a domestic version of the picturesque... It is a household weapon for taming the landscape"

Jackie Bowring discussing window symbolism in New Zealand art. (Bowring 9).

\section{A window}

Windows have been standard building practice for thousands of years. Defined as an opening in a building, ship or carriage as a means of supplying daylight and ventilation, the function of a window had changed little up until the eighteenth century (Oxford English Dictionary, “Window, N").

A window is comprised of a frame and in most cases a pane or shutter system - allowing control over the amount of light and ventilation from outside. Its role in presenting an outlook of the surrounding world is a more recent development that began with a bay window. This role has evolved alongside attitudes to landscape and technical discoveries relating to glass.

As noted previously, the framed frescos of the Classical era were 

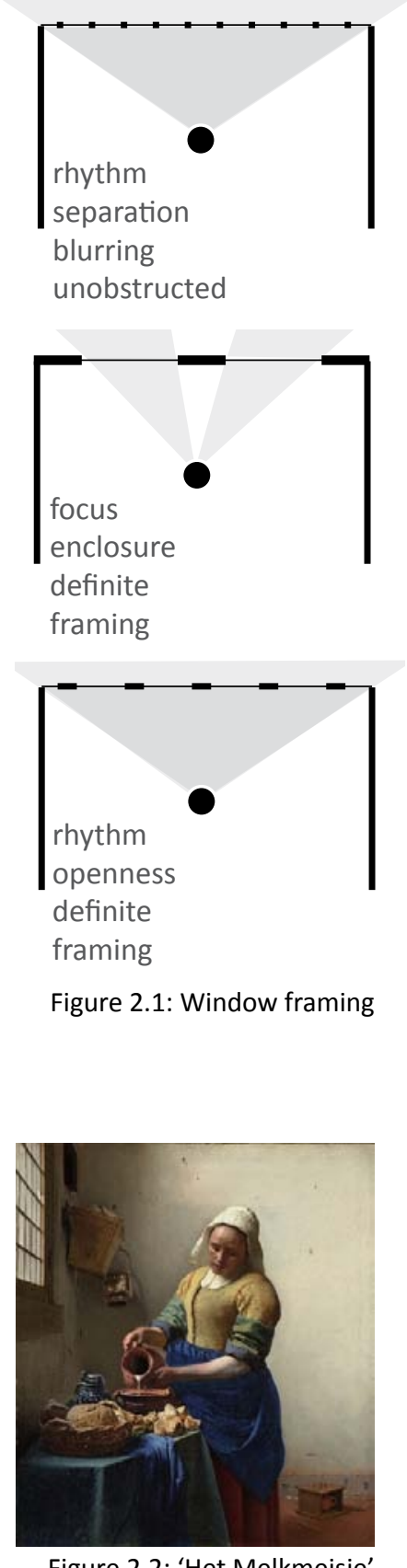

Figure 2.2: 'Het Melkmeisje'

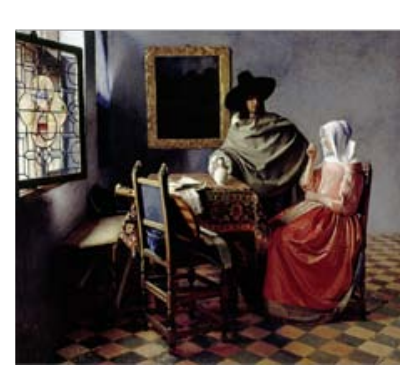

Figure 2.3: 'Het Glas Wijn' a metaphor for what could be seen from a window. Window symbolism can be seen as far back as ancient Egypt, and has continued through Medieval times to the more modern, secular notions of a window (Gottlieb). Windows have been associated with God, the Virgin Mary, women and the screens of computers and television sets. Over thousands of years, the window has been described as offering protection and separation.

A frame of a window appears to be the element of a window system that carries most of these associations. In the following extract, Francis Pound highlights the importance of a frame.

“The frame is a family sign of 'depictivity', a sign we are seeing not the world, but a depiction of the world. For the world is not framed, nor are things in it. We do not see life sliced at it edges. The eye dances, sees neither edge nor end. And so the frame prevents us mistaking painting for nature" (Pound, Frames on the Land 13).

Translating this encourages consideration of not just a window frame, but all elements of a house which create a boundary to the outside. In this way, the architecture of an interior is a frame which establishes a distinction between a depiction of landscape and land itself.

The following two paragraphs offer two examples of window symbolism in art and literature. The first is from the seventeenth century, Dutch artist Johannes Vermeer used windows in his expressions of domestic interiors. The use of a painted window was for Vermeer a symbol of separation and enclosure, as represented by the woman who posed in many of his works, separated from the outside world. The window is closed as a woman works beside it (figure 2.2), but opened, when a man stands in the way of the window, hovering over a sitting woman (figure 2.3). These paintings, the first of domestic scenes rather than religious events, demonstrate an understanding of the symbolic role of a window as a boundary between freedom and constraint.

In the middle of the nineteenth century, the French poets Baudelaire and Mallarme wrote of windows in terms of "verticality, framing, interiority, as conditions of genuine poetic experience" (Kenzari 41). Apollinaire, a French poet, wrote fifty years later of windows as "freedom, simultaneity, openness, panorama and exteriority" ${ }^{4}$ (Kenzari 38).

In the sixteenth century, the use of glass became common place in buildings, introducing a new mode of window. Scientific and technological progression from this point allowed windows to better control and manipulate daylight and ventilation. However, "until 18th Century, the idea of a "room with a view" would have been anathema to most people" (Baillieu 15). The change in the role of a window aligns with a shift in attitude towards viewing landscape.

The increased use of glass saw the introduction of window and glass taxes in Britain in the eighteenth century. A domestic window had transformed into a privilege - a taxable commodity 5 .

With the eventual abolition of the glass taxes ${ }^{6}$, bay windows were developed in the eighteen-seventies. A bay window was device to obtain greater sense of space inside and a wide view of the outside, from within the safety of a home. Significantly, a bay window was the first time a window was considered part of the design of a house; the first time "a window as an architectura opening for light and ventilation ceded its priorities to the modern function of the window: to frame a view" (Friedberg 103).
4 The change in the use of a window metaphor forewarns the architectural debate in the early twentieth century and subsequent shift in thought and practice of a window.

5 The first window tax was introduced in Great Britain in 1696. It was a flat tax per household, and then increased as amount of windows increased. Seen as a tax on light and air it was begrudged and unpopular until its abolition in 1851. A second tax was installed 1746 until 1845. This tax focused on the weight of the glass within the window, thus resulting in a period of manufacturing very thin and weak glass.

${ }^{6}$ The ending of window taxes appears to have coincided with the completion of the Crystal Palace, in 1851. The Crystal Palace exhibition building was constructed nearly entirely out of glass supported with steel and timber framing. 


\section{Modernism in architecture}

"Everything in these houses seems to be disposed in a way that continuously throws the subject towards the periphery of the house. The look is directed to the exterior in such a deliberate manner as to suggest the reading of these houses as frames for a view"

Beatriz Colomina describing the architecture of Le Corbusier (Colomina 98).

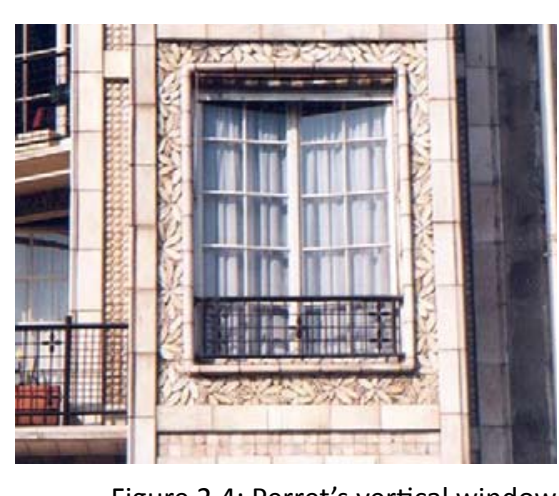

Figure 2.4: Perret's vertical window

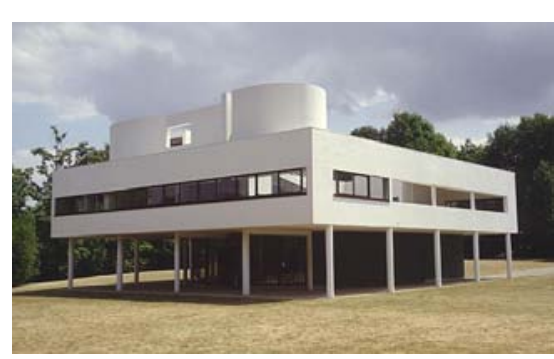

Figure 2.5: Le Corbusier's ribbon window it defines a place and a threshold, establishing a relationship
Le Corbusier was a key instigator behind the transformation that the modernist movement had on residential windows in the early twentieth century. In 1923, in the architectural section of the journal Salon d'Automne, Le Corbusier and his predecessor August Perret engaged in an extensive debate about the virtues of an ideal window. The animated dialogue defended traditional vertical windows (figure 2.4) against a new horizontal, ribbon window (figure 2.5). The argument is referred to extensively in historical discussion of domestic windows.

Perret, in defence of the vertical window, spoke of a window which opens "the interior to the exterior, but at the same time of spatial and emotional exclusion" (Kenzari 39). He refers to enclosure, safety and the loss of genuine experience through the use of a horizontal window (Relchlin). This lost experience, he claimed, was due to the limited depth of view produced from a horizontal window.

"The scenery is there, in its direct immediacy, as if it were glued to the window because either a detached and calming effect is denied, or the transition from the nearby, familiar objects to the more distant ones hidden from view, which significantly reduces the perception of three-dimensional depth" (Relchlin 181).
Perret was not alone in attempting to rein in new characteristics of a modern window. In both Europe and America, many architects felt that the large panes of glass requested by clients were endangering the long-standing character, privacy and comfort of domestic architecture (Isenstadt, The Modern American House) Whilst there was a general agreement in a design of an enlarged window if it displayed a prospect of significant beauty, for the most part, the architectural profession believed undue emphasis had been placed on an visual connection to the outdoors, at the expense of the home's real priorities (Isenstadt, "Four Views, Three of Them through Glass").

Throughout the ninetieth century, the production of glass continued to be refined in both quality and price. By the early twentieth century, window and glass manufacturing companies were actively promoting new possibilities for glass, attracting considerable interest from architects and homeowners in both Europe and America.

A modern window, in Le Corbusier style, quickly became popular. Le Corbusier's contention was that a window is a mechanism of championing "light, the external, the blurring of the inner and outer, simultaneity, modern communication, and detachment" (Kenzari 45). With recent developments in photography, Le Corbusier proved to Perret that a horizontal window increased introduction of light (Colomina). To Le Corbusier, a window was a lens of a camera and the object in focus was the outside world.

This relocation of the character of a house to the periphery of a building is one of the principle changes seen within the modernist movement. An early twentieth century window has been described as displacing a fire hearth as "the spatial, mechanical, social and structural core of the house" (Isenstadt, "Four Views, Three of Them through Glass" 216). In this way, windows have become the icons and symbols of a modern way of life. In line with the aims of this project as set out in the 
7 The modernist notion of transparency has been defined as having two strands - literal and phenomenal. Consecutively, "transparency may be an inherent quality of substance, as in a glass curtain wall; or it may be an inherent quality of organisation".
Colin, Slutzky; Rowe, Robert, Iransparency (Basel: Birkhauser Verlag, 1997) 23.

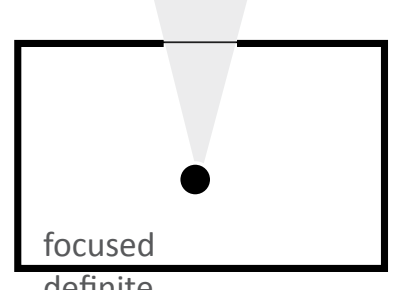

definite secure

captured exclusion
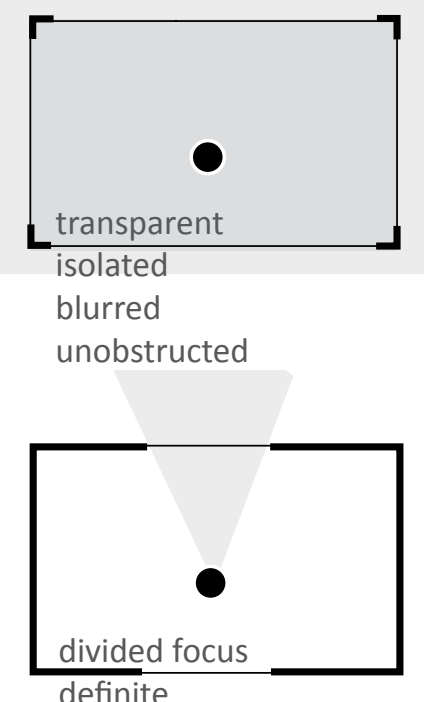

definite
insecure

exposed

Figure 2.6: Enclosing an interior diagram introduction, the design phase of this thesis seeks to challenge this role.

This new domestic relationship to landscape led to notions of a suburban dream, particularly within America. "It signalled a modern domestic pastoralism: a humble home, a welcoming landscape, and a cosy fellowship between them" (Isenstadt, The Modern American House 179). People flocked to new suburban developments with the promise of an unimpeded view for all. These views were captured by large landscape and picture windows, separating the role of ventilation from main windows to allow larger panes within a thinner structure.

Modernist all-glass walls reinterpreted the function of a window. A building by the middle of the twentieth century required no apertures to see through; only one main material was needed to construct a transparent ${ }^{7}$ glass-box (Friedberg). Inexhaustible in size and form, glass panes no longer required large structural frames or hinge systems, allowing modern buildings to visually involve and revolve themselves around their surroundings. The nature of these buildings generated a hierarchy within the human senses, displacing vision at the top, separated and isolated from the other four senses (Sennett).

The all-encompassing use of glass in a commercial environment remained prominent throughout the twentieth century, compared to its use in the domestic scene. In residential architecture, the tension between privacy and openness dissipated in the nineteen-fifties with the introduction of television. As a television took presidency over a view, the orientation of a home was changed to accommodate this: "television was absorbed with the home in accordance with a logic of looking pioneered by the view" (Isenstadt, "Four Views,
Three of Them through Glass" 231).

Both viewing a physical depiction of land through glass, and the virtual one, through a television screen, came to embody a new function for a home in the twentieth century - "visual recreation" (Isenstadt, "Four Views, Three of Them through Glass" 232).

\section{Conclusion}

For the growing middle classes, a home had become a place to safely watch the rest of the world. The last two chapters offer two lines of history which have shaped and determined the current role and value of a view. From a past within art as well as science, notions of view have travelled across disciplines over the centuries, and have become ingrained in cultural and technological development.

The following chapter examines roles of a view from three different areas of twentieth century research. The first section begins to extract relevant information on a theory of vision, which was subject to considerable scientific analysis in the twentieth century. Aspects of this theory offer interesting insight into why western society may seek access to a view.

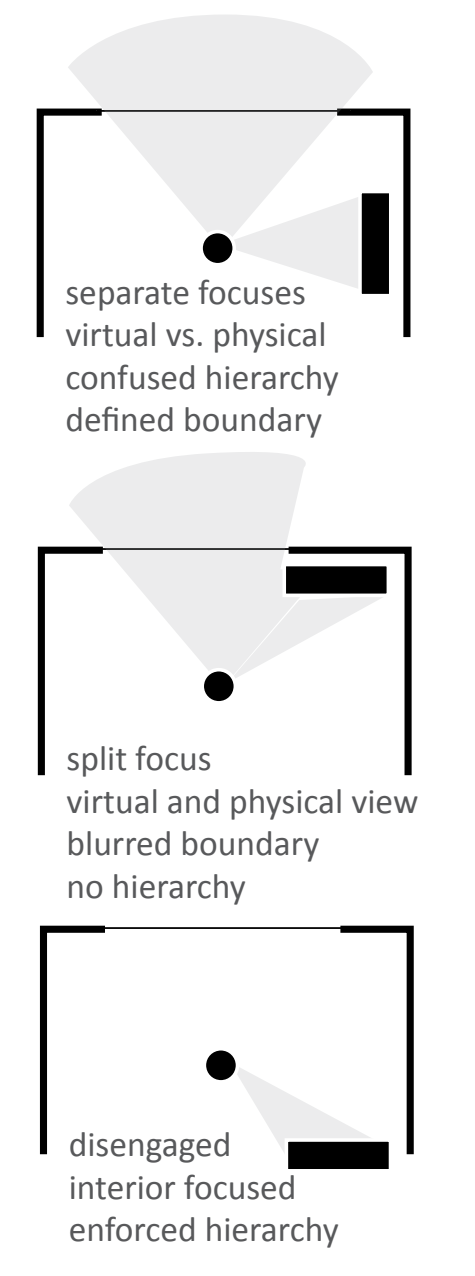

Figure 2.7: Television versus a view 


\section{Chapter 3:}

\section{A view in the twentieth century}

This chapter is a summary of readings in three areas of research: Gyorgy Kepes' theory of vision, modern art and psychology of a view. A full consideration of these issues is beyond the scope of this research but several aspects pertinent to the aims of the thesis have been discussed below.

\section{A theory of vision}

"We know the world by what we see: through a window, in a frame, on a screen... how the world is framed may be as important as what is contained within that frame"

Anne Friedberg discussing the significance of a frame (Friedberg 1).

The Language of Vision, written in the nineteen sixties by Gyorgy Kepes, offers several interesting points, relevant to the manner in which architects might prioritise design in relation to a view. A large amount of Kepes' research focuses on influences a human mind has on vision. Interpretations made in a human brain while it organises scattered light rays from the eyes suggest that the delivery of an image is as important as the content (Kepes). This thesis proposes that the placement of every built element might alter not only what an occupant sees but how a building and its surroundings are in turn perceived. 
(...........

(...........

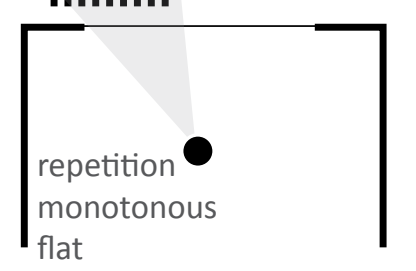

focused area

(.................

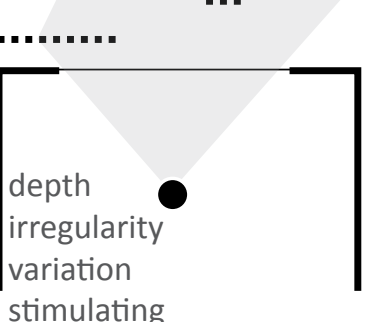

stimulating

......

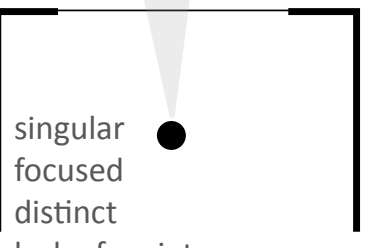

lack of variety

Figure 3.1: View patterns
Kepes further considers a field of attention - a "readiness to perceive" in human minds (Kepes 44). He proposes that interest in an image is determined by the two limitations of a human's attention. The first limitation is the amount of information or light rays a human brain is required to interpret and the second is the time a brain is prepared to focus on an image (Kepes) Kepes discusses a need for variation and change to occur within an image in order for interest to be sustained over a period of time. However, there reaches a point when the level of complexity within an image is beyond the ability to decipher order to retain the attention of observers, he believes clarity and variation are important in a visual image.

While Kepes focuses on two-dimensional imagery of art and advertisements, his theory translates well in a context of a flattened landscape depicted through a window. The book offers a series of techniques often used in images to provide continued interest. Whether objects within an image are spots or mountain ranges, incorporating qualities of nearness, similarity, closure/continuance, rhythm and movement help generate ongoing interpretations within a human brain (Kepes). These characteristics are perhaps simpler for artists to control in their paintings, yet the manner in which a window frames and focuses aspects of an external environment could be used to decipher and present these elements. Kepes' argument expands on existing notions of vision such as the picturesque concepts of distance, irregularity and variety and endeavours to define and refine their effects. Not only are many of Kepes' ideas illustrated in modern art, his use of modern representation in the Language of Vision highlights a connection.

\section{Modern art}

Much art of the nineteenth and twentieth centuries was used to explore vision in a novel way. The mastery of painters in reproducing picturesque landscapes appears to have reached its height in the eighteenth century.

In the last two centuries architects constructed domestic spaces for a new appreciation of landscape spectatorship. At the same time, painters challenged the role of a spectator in art. Cubist and futurist artists such as Pablo Picasso offer an interestin parallel to an architectural modernism of the time (Friedberg).

Modern art has two approaches relevant to a study of an architectural understanding of a view. The first is a departure from a naturalist representation. This allowed modern artist to question the limitations of a fixed, singular and frontal location of a viewer within linear perspective (Crandell). The ability of photography and film to capture multiple points of view simultaneously sparked an interest in artists as to the possibilities of capturing this notion in a painting. Similar to a transparent architecture of Le Corbusier and other modernis architects, multiple views began being translated in artists' work (Friedberg). By painting beyond a literal illustration of their subject, artists were able to infuse more information in their art than could be traditionally represented.

Pablo Picasso utilises this technique extensively in his paintings to illustrate an object in its entirety (figure 3.2). He indiscriminately depicts every back, top and side angle within one surface (Friedberg). With respect to this thesis, the notion of multiple viewpoints speaks of an architecture surrounding a view. For example, a bay window begins to offer a greater level of threedimensionality, while modern art suggests a more extreme translation of a landscape.

The second theme within modern art relevant to this discussio follows on from the notion of illustrating beyond what is commonly seen. As discussed in the Language of Vision, most art of the twentieth century is not about resembling the object

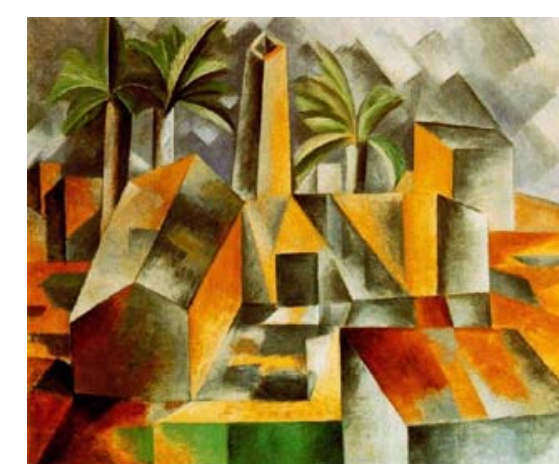

Figure 3.2: 'Factory at Horta de Ebro'

Figure 3.3: Multiple viewpoints
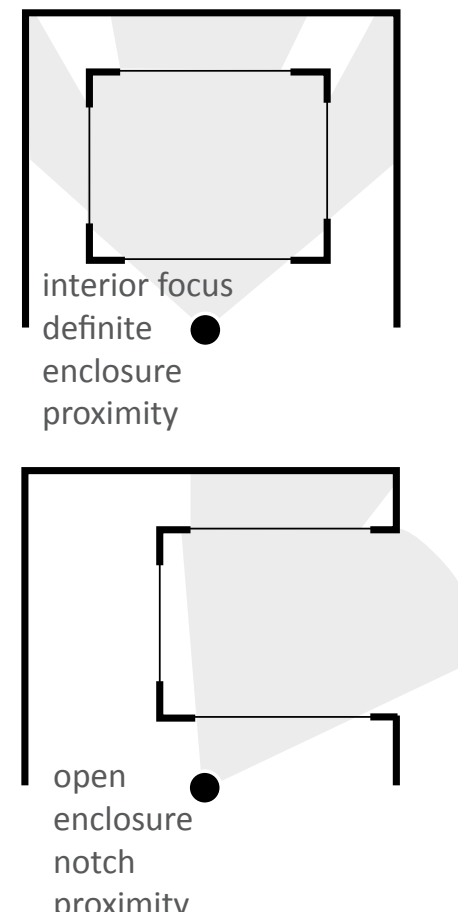

proximity

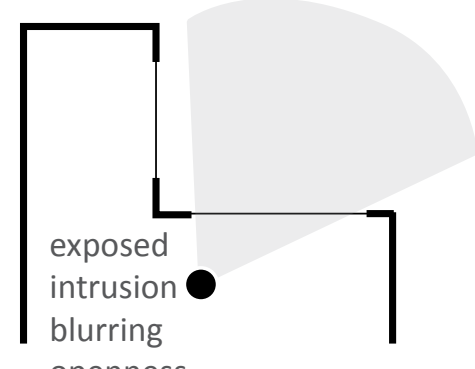




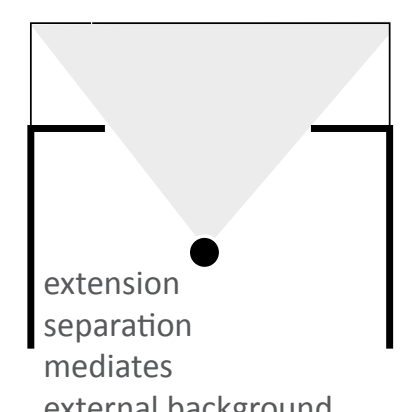

but about portraying the sense of such object to an observer (Kepes). It is suggested that modern artists have turned the focus of their art on its head; the subject of their work is no longer religious figures or landscapes but "the perceptual experience of the spectators themselves. The emphasis is on the seeing rather than on what is seen" (Crandell 161; Tunnard). This altered objective allows artists to conceptualise objects in their art at an abstract level, as if an object itself was insignificant. The translation of this notion into an architectural environment highlights the importance of a frame and threshold between interior and exterior spaces. If the focus of a domestic dwelling is an abstracted image of a view, objects within its sight may be accorded less significance than the manner in which they are captured and understood within a spatial layout of a house. In contrast to Kepes' theory and modern art which promote notions of framing, the following section discusses the psychological importance of a view.

\section{Psychology of a view}

Following on from a manipulation of a visual image in early twentieth century painting, many research studies aimed to construct a more definitive understanding of the consequences and value of a view. These studies, completed mainly in the later part of the twentieth century, provide empirical evidence of benefits of a view. Each study engages with very specific settings, most often in an office, school or healthcare environment. They demonstrate benefits of a window outlook for improved health and concentration.

Rachel Kaplan, an expert in this area of environmental science, dissects the psychological value of window views into two points in her study, 'the Nature of the View from Home, Psychological Benefits'. The first benefit, she explains is that the "special status of windows is related to the fact that views out the window readily draw one's attention. These pulls of attention in turn lead to very brief interludes that can provide a respite from the immediate tasks and demands, thus providing a microrestorative experience" (R. Kaplan, "The Nature of the View from Home, Psychological Benefits" 508).

The ability of an outlook to restore attention appears to be mostly related to the content of a view achieved by three notions: away, extent and compatibility ${ }^{8}$ (R. Kaplan, "The Nature of the View from Home, Psychological Benefits"). These factors were previously determined by Rachel and Stephen Kaplan as key aspects in their theory on attention restoration ${ }^{9}(R$. Kaplan and S. Kaplan). The placement and size of a window's fram and mullions are noted, within the study, as likely to contribute to attention restoration as well as a sense of safety and refuge windows offer

A study on the academic underachievement of inner city children considers the role of self discipline in improving attention spans and examines how the proximity of natural settings to the subject affects their attention span ${ }^{10}$ (Taylor). Another study suggested that a window view from a college dormitory could increase a college student's ability to direct attention (Tennessen). This study notes that the influential factor was what could be seen, not the fact of being able to see. The extent of the students' attention appeared to decrease with outlooks onto built elements or obscured natural settings.

The second point Rachel Kaplan presents in her study noted above, is a possible sense of well-being generated from window view (R. Kaplan, "The Nature of the View from Home, Psychological Benefits"). This psychological effect is suggested to be directly based on the content of an outlook.

"Natural elements or settings in the view from the window contribute substantially to residents' satisfaction with their neighbourhood and with diverse aspects of
${ }^{8}$ The three definitions are defined by Stephen Kaplan in 'The restorative benefits of nature: toward an integrative framework'. The term 'away' refers to a sense of removal from one's current situation or location, 'extent' implies a need for a richly stimulating environment and 'compatibility' is the ability of the environment to offer what the person desires. Stephen Kaplan, "The Restorative Benefits of Nature: Toward an Integrative Framework," Journal of Environmental Psychology 15 (1995).

9 Attention restoration theory is a conceptual framework involving the notion of mental fatigue, the result of prolonged concentration. Rachel and Stephen Kaplan propose sleep as a remedy as well as the micro-restorative experience a window view can offer.

${ }^{10}$ The results of this study were a correlation between the proximity of a natural setting and increased levels of self-discipline within the examined girls, yet little connection was found with boys. The conclusion of the study noted several possibilities for this result: the most promising explanation was that the disposition of boys to roam had led to contact with natural settings that were further from home. 
their sense of well-being. Views of built elements, by contrast, affected satisfaction but not well-being. Views of the sky and weather did not have a substantial effect on either outcome" (R. Kaplan, "The Nature of the View from Home, Psychological Benefits" 507).

This is observed in another study: the "opportunity to view trees and woods through the window had a significant positive effect on residents' response to their social as well as physical environment... the more friendly, supportive, and attractive they rated their neighbourhood" (Heerwagen 625). This sense of wellbeing has been translated into a multitude of other scenarios; increased brain function in intensive care units, a restorative effect seen in postoperative patients in rooms with a view, and improved health of prison inmates who have windows opening onto a natural view (Keep; Ulrich; Moore)

Within all these studies, looking out onto a natural environment delivered a greater ability to concentrate and a sense of wellbeing. The most significant feature in the research studies gathered for this thesis is the content of the outlook, with natura views, particularly vegetation and water, providing the greatest health benefits. In a study on possible benefits of a view from a window within an office environment, Rachel Kaplan places importance on "proximately and availability of the natural environment" (R. Kaplan, "The Role of Nature in the Context of the Workplace" 193). Kaplan comments that an employee does not need to spend a large amount of time near nature to benefit from it. Another study noted that the majority of windowless offices are decorated with visual images, usually dominated by natural landscapes as a means of compensation (Heerwagen). All of the studies mentioned not only suggest observation of nature improves health, they propose that it is a subconscious human need.

\section{Conclusion}

This evidence suggests that an observation of landscape is more than an aesthetic issue, it is a subliminal human requirement. It suggests that urbanisation and the reduction of accessible natural landscapes has driven an inclusion of nature in domestic design.

The following chapter explores this desire further, within twentieth century New Zealand context. It engages a number of fields of research in an attempt to better understand a desire for a view and the consequences of this for domestic architecture. 


\section{Chapter 4:}

\author{
A New Zealand Context
}

New Zealand offers an interesting perspective on a contemporary notion of view for both its limited building history and its range of natural landscapes available to observers. Most of New Zealand's domestic construction, post colonisation, was completed in the nineteenth and twentieth century. New Zealand therefore presents an opportunity to consider the architectural changes that have occurred in the past one hundred year period.

Much of this change has already been analysed by others. By the end of the twentieth century, architectural theorists had begun deciphering the changes in local and national modes of domestic design, attempting to define a distinctly New Zealand architecture. The last twenty years has seen a number of publications on New Zealand architecture and landscape, covering developments over the course of the past century. Although the architectural treatment of views receives indirect comment in many of these publications, there is very little critical writing that explores the subject.

While offering some comment on the architectural themes in terms of the treatment of a view, the main insight within this literature appears to be the international nature of twentieth century domestic architecture. There appears to be little difference between New Zealand attitudes towards a window view and a European or American position. The only significant difference suggested by these writings is the importance that 
New Zealanders place on the variety of landscapes within this country, and the tourism that New Zealand landscapes generate.

\section{New Zealand housing}

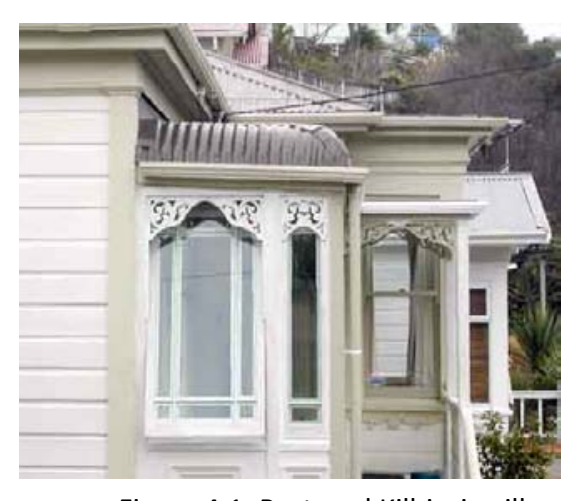

Figure 4.1: Restored Kilbirnie villas,
Wellington
The early part of the twentieth century saw two main types of housing constructed throughout New Zealand. These were direct translations of the British Victorian Villa and the Californian Bungalow. Constructed from detailed kit sets, these houses followed the enclosed and formal characteristics of their international forbears. Cottages built up until the middle of the century offered little visual connection to their surrounding landscape as they were based around the same priorities which drove the original designs. The second half of the century saw a new housing style with a clearer visual and physical focus on a house's exterior surroundings. Nonetheless, a villa and its various forms and iterations have retained a strong place in New Zealand housing typology because of subsequent alterations, in many cases precisely to access a view of a surrounding landscape.

New Dreamland is a book which brings together the essays of many well-known New Zealand architectural theorists of the twentieth century. It offers an account of a progression away from international imitations in an attempt to construct a local tradition. This book presents a development (albeit selective) of window trends over the century. This starts with an essay by Gerald E Jones in 1912, arguing:

"Good taste declares against large panes of glass in the windows of a house, although many people prefer them. Large sheets of glass have the effect of dwarfing the appearance of the rooms and throw a small apartment out of proportion" (Jones 35).

This inside focus is reiterated in an anonymous text in 1936:
"It would be well to consider carefully whether you really require such broad windows, or whether a few tall windows of generous width, tastefully draped and framing a pleasant glimpse of garden or distant landscape, will not better produce the idea of home" (Anonymous "Evolution or Revolution: What New Zealand Architects Are Doing with Modernism" 81).

There is a discernible plea in this extract voicing the appeal by many early twentieth century architects for a concentration of the interior conditions of a house as opposed to a growing priority of the world outside. Within ten years a counter appea is argued in the following writings by Ernst Plischke in 1943, and Paul Pascoe and Humphrey Hall in 1946:

"The rest of the windows are planned so that they will not interrupt the view from inside. A band of windows is suggested, so that the horizontal lines of the mountain ranges are not cut off by wide walls between single windows" (Plischke 128).

"Room shadows cast by over-dominant interior wall areas are eliminated by the use of large windows...glass close to the floor line brings the garden 'into' the house, and conversely takes the "house' into the garden" (Pascoe 133).

A shift away from a Victorian architectural style led to the Group, a gathering of New Zealand modernist architects. First a collective of architecture students, and later an architecture and construction firm, Group Architects sought a New Zealand based and generated architecture (Gatley). While closely following many international trends of the time, including the international modernist focus on a transparency between inside and out, this group of young architects attempted to translate aspects of New Zealand culture into a definable architecture. The Group, along
Figure 4.2 and 4.3: The Group's Roberston
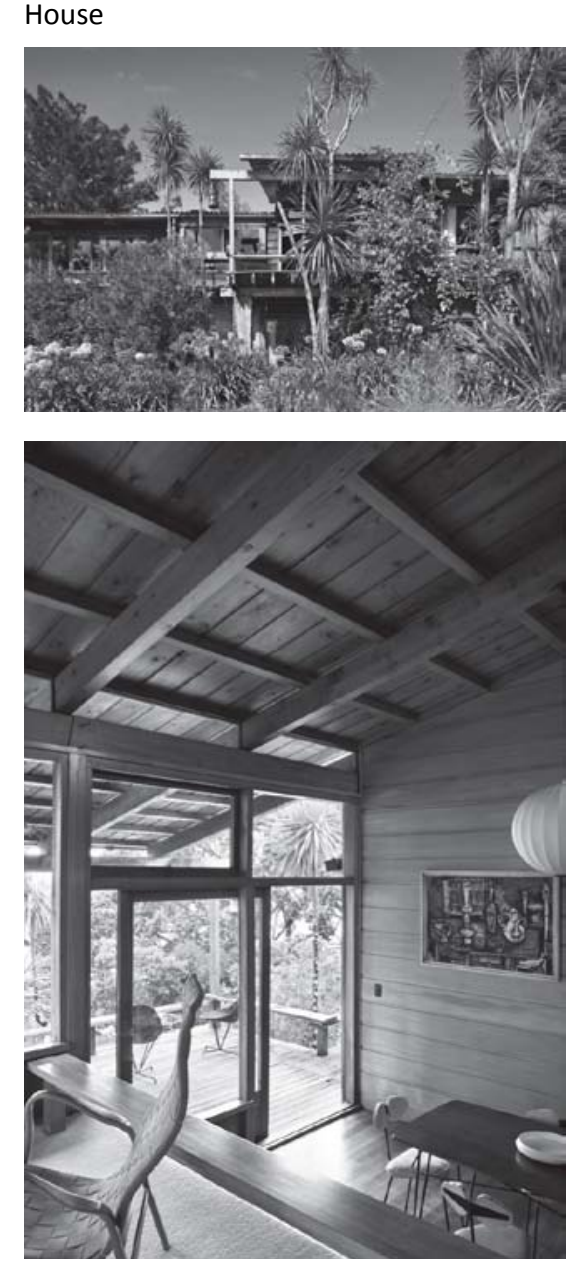
with many other firms and individual architects over the next fifty years, guided New Zealand toward a fascination with glass, an 'indoor/outdoor flow' and an uninterrupted view.

Many New Zealand architects and architectural theorists are now critical of this singular focus on a connection to the exterior, for a range of reasons. For example, Peter Wood criticises the popular notion of openness in New Zealand architecture. In Wood's view, this openness appears to be a synonym for the idea of modernist transparency. Wood criticises a particular New Zealand house of this model as having "no clear delineations, no hierarchy of space, no volumes, which is in a sense the complete breakdown of architectonics of domesticity. In the end the person that provided the furniture contributed more to the spatial organisation than the architect" (Wood).

These critics are a reminder of the appeal that took place a hundred years earlier for greater consideration of an interior of a house. Wood presents this line of argument with an example of a house designed by Mike Austin in Takapuna, Auckland. Wood provides little comment on the architecture of the house itself, noting the price tag placed on "a Modernist New Zealand house with poor access. Sadly, it is more probably the view than Austin's touch that makes this such unreasonably valued real estate today" (Wood). Wood appears to question the integrity of clients as much as architects in this discussion. He challenges what he sees as a desire a to "see something in our landscape and treat it as though it is untouched when everything out there if you look at it, is the product of really quite violent interaction" (Wood).

Wood's criticism here is also of the pretence concerning New Zealand's "uninhabited" landscapes and the attempt to blur the boundaries of a house and surrounding land. He sees that the national mode of architecture has become one of concealment and suppression of nature's history and certain qualities of landscape ${ }^{11}$.

Exquisite Apart: 100 Years of Architecture offers a more recent account of architectural analysis. It includes, as well as a further essay by Wood, writings by David Mitchell and Dorita Hannah that reinforce the argument for attention to interior design:

"The department of conservation appears to be firmly opposed to architecture at all... disguise is the form favoured by local authorities, and dismal green and brown structures are readily approved" (Mitchell 140).

"New Zealand continues to insist on describing itself within the global imagination as a curiously bucolic wilderness rather than construction of an identity through cultural practices and the built environment" (Hannah 184).

Based on these extracts, it is suggested that New Zealand's fascination with the visual qualities of the nation's landscapes can constrain an architect's willingness to balance a fully considered interior organisation and the position a building has within its site and access to a prospect of the outside landscape.

\section{The real estate market}

New Zealand's uninhabited shorelines and hills have also become a fixation for the nation's real estate industry. The follow discussion comes from a research study on the advertising of coastal properties in New Zealand. Authors, Damian Collins and Robin Kearns use quantitative data collected from New Zealand real estate advertisements, comparing this to internationa studies, to demonstrate the significance of a view in real estate terms.

"We find views from private property over the coast often prioritized in advertising, while the coast itself is typically portrayed as devoid of people. This invites viewers to
${ }^{11}$ The line of criticism of architectural treatment of a view in New Zealand is relevant to this discussion in that it raises the issue of balance and integrity in the presentation of a view relative to the whole architecturat design of a building which this thesis aims to explore.

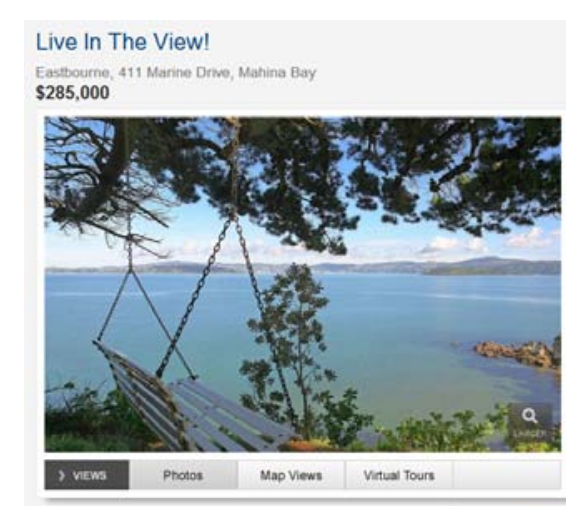

Figure 4.4: Harcourts advertising 
12 "The most striking feature of this sample of advertisements was the extent to which many communicated relatively little, and sometis no, information about characteristics 'internal' to the dwellings and lots for sale. Rather, the emphasised the property's location relative to the coastal environment. This emphasis took two prominent forms: on referring to the literal proximity of the site to the coast and the other to the views of the coastal environment the property afforded". Damian Collins and Robi Kearns, “Uninterrupted Views: Real-Estate Advertising and Changing Perspectives Environment and Planning 40 (2008): 2925

${ }^{13}$ There is a deception in this as well. Unless a view in it's entirely is part of a property's land, an owner has no lega rights with respect to it. While local counci regulations offer restrictions to sunligh access, a view has not been addressed in any body of regulations; it is yet to be legally owned. place themselves in the image - as prospective property owners - and appeals to notions of going to the coast to secure privacy and opportunities for passive relaxation" (Collins and Kearns 2914).

Interestingly, this study suggests that an ideal outlook from a property is one devoid of people. This notion of solitude, a major reccurring theme in New Zealand colonial and post colonia painting is discussed in the following section of this chapter.

The notion of privacy from others within a view is further discussed in the study by Collins and Kearns in a non-New Zealand context. In the study 'Advertising modernity: home, space and privacy', SCH Cheung, proposes that Hong Kong's views are "an extension of the home's private space - something that can be possessed and privatized" (Collins and Kearns 2922). This sense of ownership is implied in many of the New Zealand advertisements Collins and Kearns studied. Through their imagery and text, agents have chosen to sell a coastal prospect in preference to the qualities of a house ${ }^{12}$ and as an exclusive element of a property ${ }^{13}$.

\section{Contemporary attitudes to landscape}

This section offers another way to understand New Zealand attitudes to landscape. The themes raised by this analysis suggest that European New Zealanders have retained their forebears' attitudes to landscape. Land promises a better quality of life. Where it has been tamed, it resembles the landscapes of the old homeland. Elsewhere, land is seen in a romantic way; people observe it rather than interact with it.

As noted above, there is a notion of privacy in New Zealand art obvious in the reccurring theme of solitude. It may be that the origins of these cultural attitudes towards a view stem from the isolated and uninhabited depictions in paintings brought back to
England during the eighteenth and nineteenth century voyages to New Zealand. Early colonial art in New Zealand was "projected onto a land perceived as silent and empty"; an invitation to immigrates of the privacy, solitude and availability of land New Zealand would offer (Pound, The Invention of New Zealand: Art and National Identity 1930-1970 31).

"A profound sense of solitude repeatedly filled the ninetieth-century European observer, especially when he or she was gazing from a high place over an unpeopled vista. The male spectator might long for his wife to be with him, or anyone other than 'savages'. In such solitude, these spectators fancied themselves ' the only inhabitants of the world - a stock device for inducing Sublime emotion" (Pound, The Invention of New Zealand: Art and National Identity 1930-1970 31).

In the book, the Invention of New Zealand: Art and National Identity 1930-1970, art historian, Francis Pound relates a sense of ownership of land to the manner in which Europeans transformed New Zealand's forests and whare into grass fields and cottages. This attempt by immigrants to mimic their homeland was not exclusively for economic or agricultura reasons. Pound, as well as other landscape theorists, suggest that this imitation was "underpinned by beliefs about what landscape 'should' look like" (Abbott, Stephenson and Ruru 17).

In the book Frames on the Land, Pound explores the nature of art and landscape further. His discussions, while given within a context of New Zealand, are not restricted to this country. He suggests that landscapes in art are very much separate to physical qualities of land itself, a theory that translates easily when considering a view from a window.

"The pictorial attitude to nature in New Zealand is a European code of behaviour. The Maori did not paint the 
14 Landscape is seen in "art and photography, on food packaging and in clothing catalogues, and on screen as the setting for blockbuster movies and car advertisements". Mick Abbott, Janet Stephenson and Jacinta Ruru, Beyond the Scene (Dunedin, NZ: Otago University Press, 2010): 13.

Figure 4.5 : New Zealand tourism website

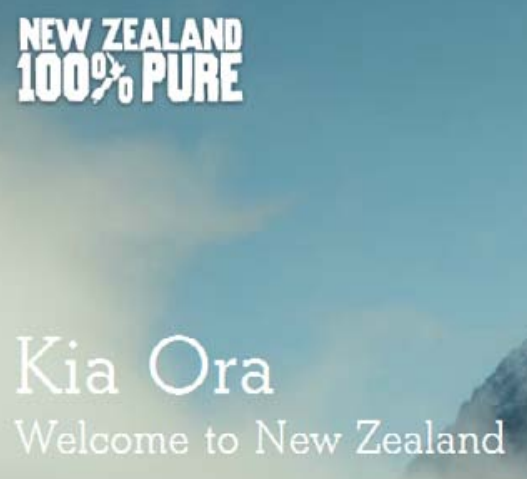

landscape, nor feel a need to. Landscape the pictorial attitude to the land, stopping still just to look at it, to see it as a picture, is purely an imported conversion" (Pound, Frames on the Land 12).

Pound's theories about the artistic treatment of landscape and a view therefore align with the discussion of historical European attitudes, as examined in Chapter one. As Pound suggests, New Zealand's interest in landscape is not only part of a European tradition, it is directly related to the way that art has treated landscape. A view of land, whether it is from the inside of a building or outside, is still based on a pictorial attitude to nature, the desire to observe nature as a removed object.

This contention is reiterated by Mick Abbott, Janet Stephenson and Jacinta Ruru in Beyond a Scene. They propose that New Zealanders limit their relationship with landscape by associating with it in a purely visual and pictorial manner. The three authors align New Zealand attitudes towards landscape to many aspects of product culture ${ }^{14}$.

Abbott, Stevenson and Ruru further suggest that a relationship with land forms is limited by New Zealand's passive and visual association with land:

"When we talk about landscape as a 'scene', it presupposes something that is intentionally staged, a constructed vision that conceals and substitutes more subtle qualities. It indicates a degree of selection and arrangement, aimed at creating something aesthetically pleasing" (Abbott, Stephenson and Ruru 197).

This extract suggests that not only is information limited through a visual relationship but the character of landscape is manipulated by this passive connection, misleading New Zealanders to many 'non-visual' qualities of their surrounding land forms. This notion of a manipulated or constructed view relates to the picturesque movement examined in Chapter One. From this discussion, it appears concealed picturesque attitudes are still in existence in a conception of land today.

\section{Conclusion}

This chapter has endeavoured to consider what drives New Zealand attitudes to a view. Before an architectural perspective comes into play, cultural influences have already affected a person's perception of a surrounding landscape and therefore the way they relate to it.

It is suggested that New Zealanders' relationship to a view is constrained by a preference for a romantic but passive relationship with a view. A view may offer a promise of a better life, but it is visual only, as well as distant and separate. It is proposed that an architectural rendering of a view ought to take this paradigm into account. Ways to achieve this will be considered in the remainder of this thesis. 


\section{Chapter 5:}

\author{
International case studies
}

The following chapter offers a specific account of five projects that have been designed around a view during the course of the twentieth century. Each study focuses on one house within an architects' body of work and has been chosen due to the significance of their relationship between internal and external aspects of the house. The five houses are representative of technological and cultural changes of the twentieth century discussed in Chapter two.

\section{La Petite Maison}

Switzerland 1923

Le Corbusier arrived at Lake Léman with the plan for La Petite Maison already drawn (Le Corbusier, Une Petite Maison, 1923). The first sketches for a house for his parents assumed three known features of the ten to fifteen kilometre strip of the available site - the lake, the Alps behind, and the south-facing aspect, all within the same outlook (Le Corbusier, Precisions on the Present State of Architecture and City Planning).

The plan of the house is a sixteen by four metre box, largely open plan, offering extended views of the lake through a south facing window stretched over eleven of the sixteen metres. Le Corbusier believed "the ever-present and overpowering scenery on all sides has a tiring effect in the long run... to lend significance

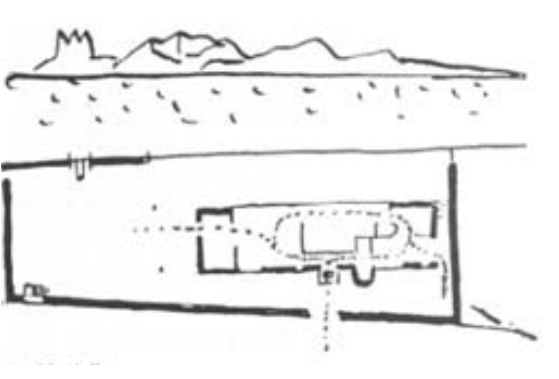

Figure 5.1 : Le Corbusier's plan for La
Petite Maison 


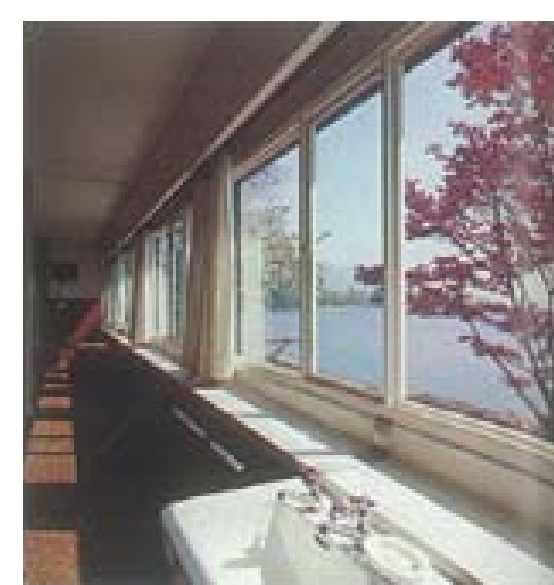

Figure 5.2: Ribbon window

Figure 5.3: La Petite Maiso
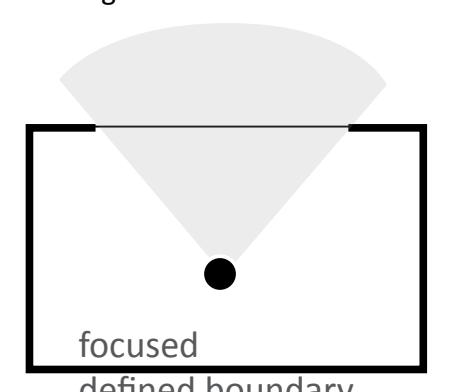

defined boundary

isolated

control to the scenery one has to restrict it and give it proportion; the view must be blocked by walls which are only pierced at certain strategic points and there permit an unhindered view" (Le Corbusier, Une Petite Maison, 1923 22). Following this line of argument, the northern entrance is the only relief in the wall until it reaches the southern side. An aperture near the western corner is cut to present a framed view beyond, designed to be viewed from an outside table. After the opening, the south wall resumes for four meters before dropping in height to reveal the surrounding scenery. From there it continues, at just above ground level, to physically separate the house from the lakefront.

Described by Le Corbusier as the "chief attraction in the house", one long south facing window generates a series of viewing frames through the various domestic spaces within the house (Le Corbusier, Une Petite Maison, 1923 30). The ribbon window travels uniformly from the bathroom, to master bedroom and lounge. Far from offering the transparency or interior/exterior ambiguity of a floor to ceiling window, the opening offers a sense of focus and definition. The design of the window's form placement and framing influences the nature of the interna to external boundary. The foreground of the view concealed by the height of the window, it is the lake and background mountains that have been captured, rendered flat due to the loss of any foreground depth. The window's proportions reflect the elongation and horizontality of the house, site and outlook.

\section{Moller House}

\section{Austria 1928}

The Moller House was constructed during the modernis period, it is an example of Loos rejecting many of the celebrated modernist features. Perhaps an interesting case study choice, it appears that the only relationship the Moller House has with the outside is one of disregard. While Loos seems to be disinterested in concepts involving exterior observation from within the house, he has given much consideration to platforms for vision of the interior. Quoted as saying "a cultivated man does not look out of a window; his window is a ground glass; it is only to let light in not to let the gaze pass through", Loos took every opportunity to distract his occupants from the view outside (Colomina 74).

The Moller House, consists of a complicated sequence of spaces, varying in ceiling and floor heights, and twisting through the two and a half storeys (Lustenberger). The emphasis in this house is in the manner in which thresholds between rooms have been composed and detailed. Loos uses a theatre metaphor to determine a hierarchy of spaces; occupants are intended to view a neighbouring space as a spectator or actor. An example of this is the threshold between the dining and music room. Although the rooms are adjacent, the two spaces are inaccessible by a $70 \mathrm{~cm}$ drop between them (figure 5.5). In this way, the music room, space of contemplation and observation, is detached from the animated and interactive stage that is the dining room ${ }^{15}$.

While windows do exist within the Moller house, they are constantly veiled by sheer curtains. The largest window exist in a small living room, raised above the rest of the first floor and suspended beyond the building's periphery. The alcove offers views into each space on the first floor as well as the ascent from the ground floor (Colomina). A couch is fixed to the base of a large horizontal window in this small space allowing little access to the view beyond the window. When the couch is occupied, the focus is inwards, offering a source of surveillance over the space so that no movement can be missed. It is through surveying the internal arrangements of the Moller house that a glimpse of the world beyond can be attained (Colomina). The back garden, beyond the music room, is the only external view visible from this viewing platform.

By not only giving primacy to the internal visual relationships but

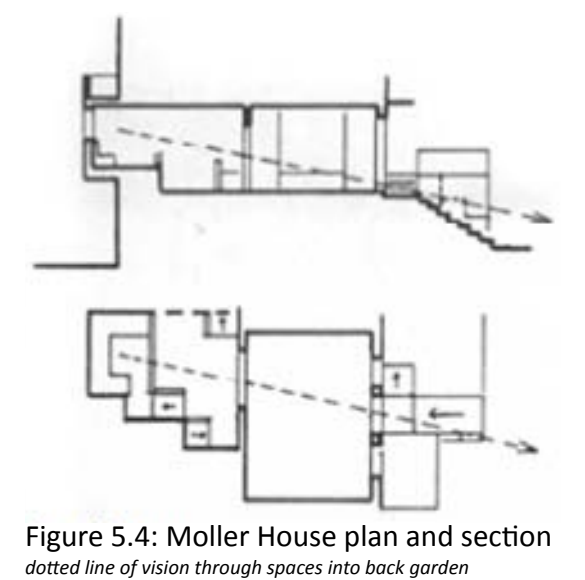

${ }^{15}$ Access between the dining and music room can be obtained by unfolding a concealed step within the threshold.

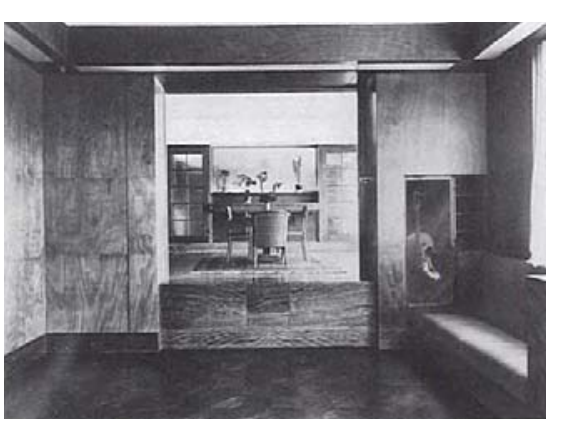
Figure 5.5: Threshold between dining and
music room 


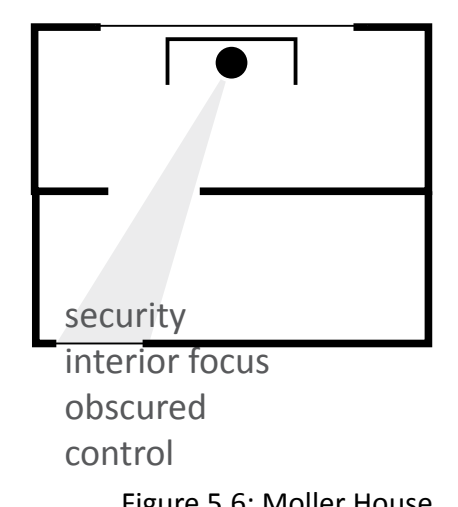

Figure 5.6: Moller House

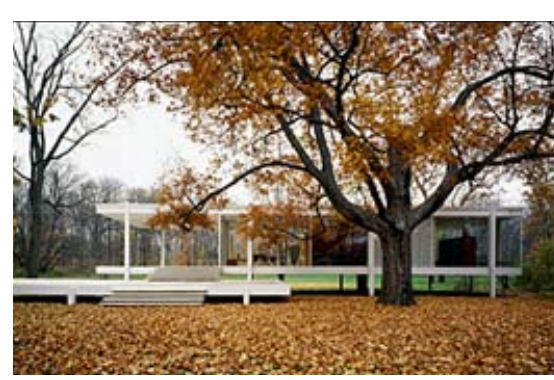

Figure 5.7 : Farnsworth House entrance

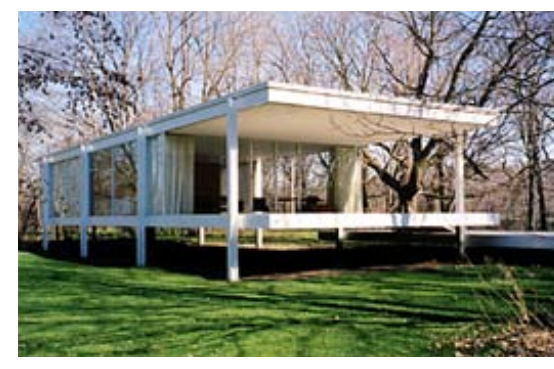

Figure 5.8: Position to groun by denying external visual stimuli, Loos reverses the tradition of external landscapes dominating an interior of a building, a technique used since the eighteenth century. The Moller House presents a revised hierarchy, where an interior spatial layout influences visual perceptions within and beyond the periphery of a house.

\section{Farnsworth House \\ USA 1946}

The Farnsworth House offers a study at the height of twentieth century modernist sensibilities. This house not only represents the vast majority of attitudes within the movement but imposes these notions upon the house uncompromisingly. Despite its original owner announcing it uninhabitable, and subsequently suing the architect, Mies van der Rohe, this house still attracts many visitors and much architectural debate. This project is no longer used as a domestic dwelling of any kind, it has become a highly valued object people aspire to observe, interact with and understand (Sunwoo).

Named after the original client, the Farnsworth House was required to accommodate Dr. Edith Farnsworth as a weekend retreat on the banks of the Fox River, a rural area outside Chicago. The shore of the river in close proximity, the house has been raised on steel stilts, lifting it just over one and a half meters above the often flooded plains (Vandenberg). To the south, a line of trees filters a view of the river, while to the north, the grassy meadow of the site rises to dense woodland. The aim of this house was to observe nature from inside (Vandenberg). The secluded setting supplies much of the visual boundaries and privacy for the house, as well as its focus on the externa entertainment.

Floor to ceiling glass walls in van der Rohe's design challenge occupants to separate the inside from out. Its transparent nature offers no control or discrimination between interior and exterior. Open to a view of the outside from all sides of house the house offers no front or back, no hierarchy of space or form. The house's open plan and scarce interior personality offer up the house as an empty vessel to be filled by the surrounding land forms. The domination of an outside view in the Farnsworth House can be seen to go beyond creating a sense of enjoyment or distraction for the inhabitants; it determines and alters the mood and use of the house.

As a domestic dwelling it has yet to succeed, but through its submissive nature and dependence on landscape, it creates remarkable rapport with its surroundings.

\section{Slow House}

USA 1991

A client's request for a vacation house with a view led architects Elizabeth Diller and Ricardo Scofidio to examine notions of view in their design of the Slow House, sited on a bluff at North Haven Point in the New York Hamptons. This vacation home is designed around three expressions of vision, prized by American society the car windshield, television and picture window (Diller). These expressions represent different forms of escape, be they virtual or physical, in the same way that a holiday is an escape from the city.

The form of the house has been described as a "distorted model of perspective". The front of the house is simply a door curving out to a large window at the "apex of the cone of vision" (Diller 38). The long slanting walls bend the axis of vision, slowing progress to the view, which is kept unknown to the visito until it is right in front of them (Anderson 103). Once through the pivoting front door, the house splits into two differen

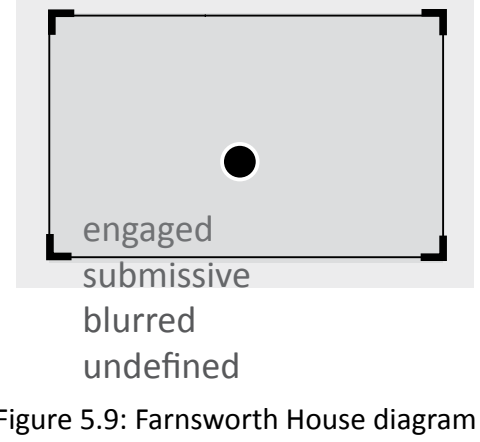

Figure 59: Finsworth House diagram

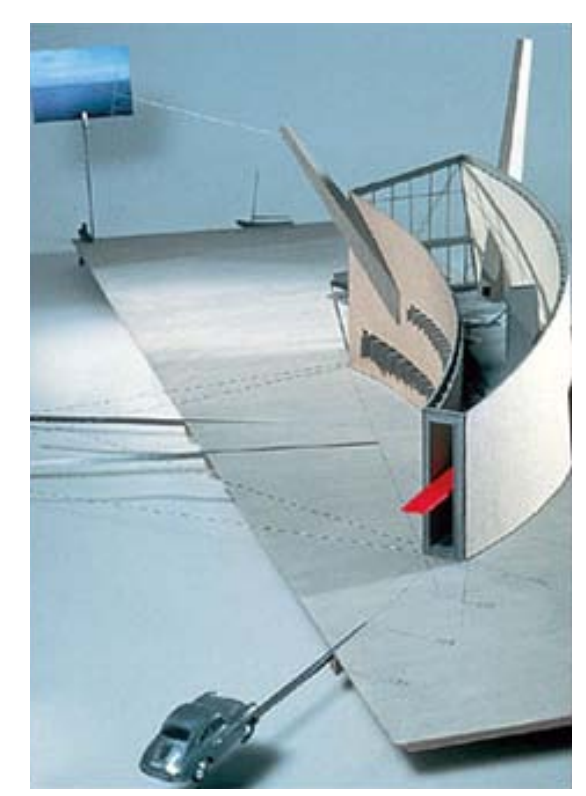

Figure 5.10: Slow House conceptual model 


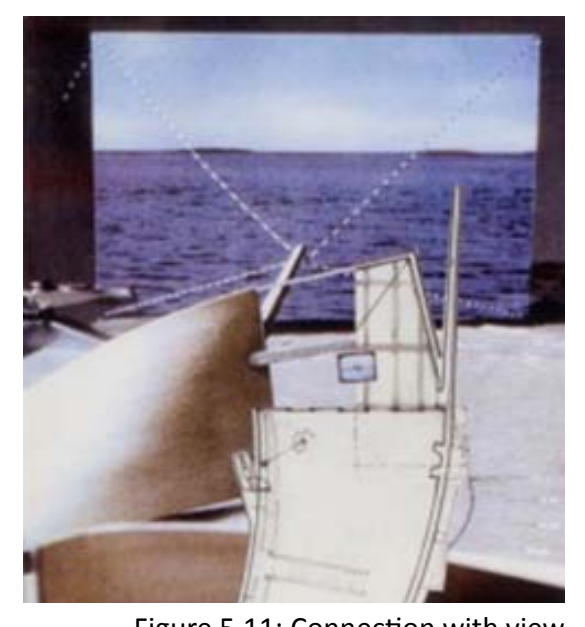

Figure 5.11: Connection with view

${ }^{16}$ Small openings have been cut along the inner arced wall upstairs, and a series of pivoting shutters run along the downstairs corridor. In each bedroom the bed's headboard appears to have pushed through the exterior wall, creating openings to a view of the sky.

Figure 5.12: Slow House
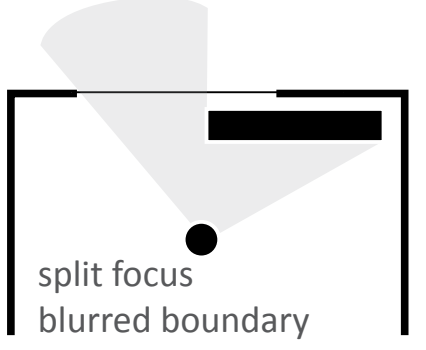

out of sync

control passageways. The kitchen, dining and living room are situated up a flight of stairs, with the bedrooms and bathrooms on the ground level. Both paths are designed to guide occupants to the living room and picture window ${ }^{16}$

In the living room, just before the outer arced wall that leads to a picture window, is a fireplace, its chimney extruded vertically beyond the house. A similar extended shaft flanks the other side of the window (Incerti). A video camera is lifted above and beyond the periphery of the house. This camera is used to capture live footage of the scene beyond a sand dune that is obstructing part of the view through the window. The electronic view is displayed on a screen hanging in front of the picture window. This blocks the vision impairment that is the sand dune, while offering an interesting dialectic of two views out of sync.

The "optical discomfort" of seeing both a view through a window as well as displayed on a screen is heightened by the various zooming, panning and replay options of the camera (La Marche 2212). As an alternative to the actual weather or time of day, the camera offers a further escape from present conditions behind the screen. Through this project the architects acknowledge that both a camera and a window are mechanisms of control by virtue of the way they isolate and objectify the exterior scene. The exterior scene as a representation has become as though a commodity, privatised and separate from the physical exterior itself.

\section{Picture Window House Japan 2002}

A house designed by Shigeru Ban completes this compilation of international case studies. This house, perhaps the simplest expression of a view yet, is situated at Izu Peninsula, an area currently devoid of urban development, one hundred kilometres south-west of Tokyo (Pirrone)

The house rests on a secluded hill slope, stretching from a wooded area at the hill summit, down to the vast horizon of the Pacific Ocean. Ban saw significance in the landscape in both directions, therefore a sense of continuation or "flow of the land" was required from the house (Pollock). This resulted in a twenty metre long truss and flanking end supports to produce an almost entirely structurally free ground floor. A sequence of glass sliding doors act as the only barrier between hill side and building. This empty volume has been designated as the living, dining and kitchen spaces with the two end supports offering a main entry, bathroom and study spanning the two storey height. The rest of the house has been placed upstairs, a series of bedrooms along a corridor which doubles as an extended, semi private bathroom.

Through both the spatial organisation and material palette of the house, Ban explores a sense of transparency to the surrounding landscape. The ground floor is denied any definable boundary through the ability of the sliding doors to open up the entire length of the building on both sides, still offering a high level of transparency when closed due to the extensive use of glass. The ambiguity of threshold is heightened by the "seamless extension" from the internal floors to the exterior porch, constructed through the repeated use of timber and uniform level between inside and out (Pollock).

The first floor offers a sense of transparency through merging the corridor and bathroom. This coupling has been noted as unusua despite a different cultural regard to privacy in Japanese culture from the West (Pollock). Themes of privacy and display are examined through the unrestricted layout and interaction within the space. These themes are reinforced through the space's tempered glass and translucent curtains which endeavour to offer some sense of separation between its functions.

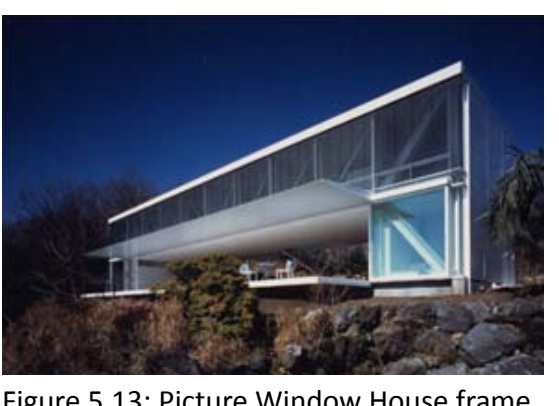

Figure 5.13: Picture Window House frame
Figure 5.14: Open plan ground floor

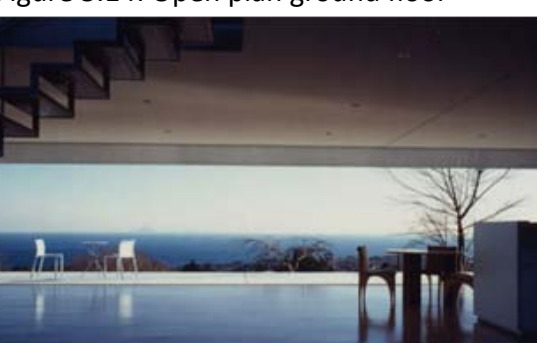


Figure 5.15: Picture Window House

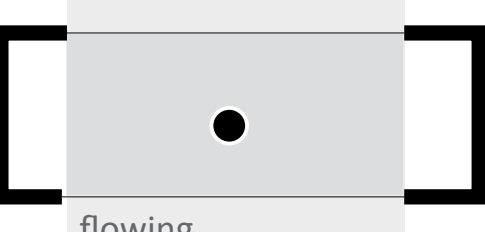

blurred boundary

defined frame

control
Similar to the ground floor, the resulting effect is a denial of the space's boundaries between programmes. Despite its initial attempt to deny its own existence, the Picture Window House does not offer itself up as an empty void to frame a view. The complexities of the programme have the effect of challenging the simple intention of the house and creating a richness of interior differences. There is sense of a confidence in the first floor as it cuts across the view - a strong frame to a picture window - as it balances the ambiguity of the boundary-less ground floor.

\section{Conclusion}

From Ban's exploration of transparency to Loos' internal vision, these examples present five different dialogues with a view resulting in very distinctive outcomes. Together the examples demonstrate responses to the challenges of creating a relationship between the visual characteristics of a site and an interior of a house. The case studies explore many theoretical and practical approaches to this relationship.

The following chapter resumes this case study approach to research in a more practical and localised manner. Three Wellington-based case studies will offer opportunities to understand, not only an architect's intentions but a client's objectives and subsequent outcomes. It presents a more personalised set of case studies, allowing a progression beyond literature based research and examples. 


\title{
Chapter 6:
}

\author{
Wellington case studies
}

In this chapter a review of a series of case studies carried out in Wellington will endeavour to uncover attitudes of both client and architect with respect to a view from a client's house. The case studies incorporate a range of construction and alteration dates over the course of the twentieth century, chosen for their unique outlook over Wellington.

\section{Orangi Kaupapa Rd \\ Northland 1926 (alteration 1993)}

This two bedroom timber cottage was one of many constructed in the bush of Wellington's western hills in the early part of the twentieth century. Its narrow promontory site offers much exposure to wind, but receives all day sun and a wide panorama of bush, city and harbour views. The site includes a small garden area along the front of the house, while an extended deck opens up the back garden to the west. To the south, the land drops suddenly, into dense bush, providing privacy from the surrounding houses nestled into the Northland and Kelburn hills. Along this south side, the original windows remain, while before the alterations in the early 1990s, the west elevation contained no openings. The orientation of the original house was largely to the north, with the entrance and largest windows in this side, displaying views of bush and hills stretching out to the start of the harbour and towards Petone. A small windowed

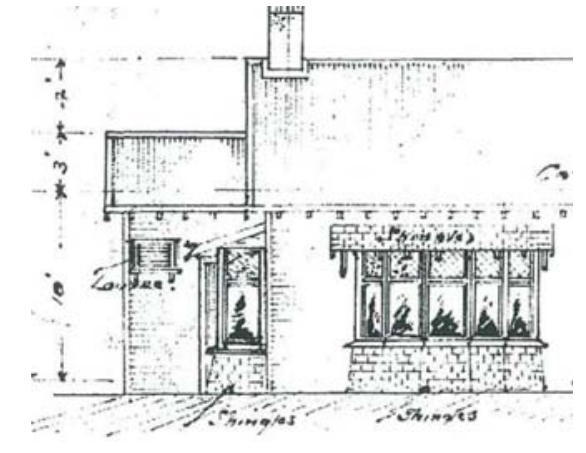

Figure 6.1: Original elevation 


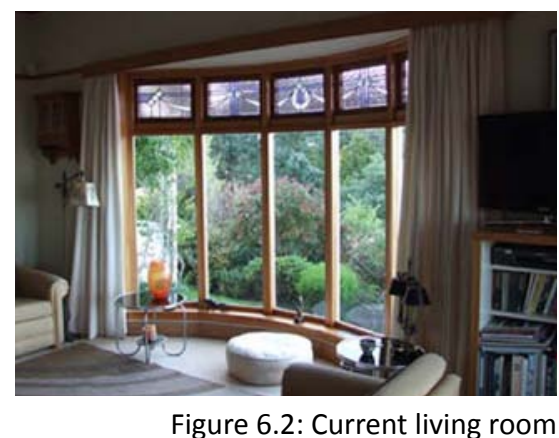

Figure 6.2: Current living room ${ }_{17}$ At the time it was sold, its extensive prospect was not brought into discussion as an amenity of the house and one of the current owners notes she took over a week to really notice the views.

18 The alteration negotiates between the original character of the house and focus on the periphery for the panoramic views. This negotiation was an issue for the couple who owned the house. From the beginning of the interview it was clear that the owners' attitudes towards view differed. One sought an extended open view and the other was reluctant to give up a feeling of privacy.

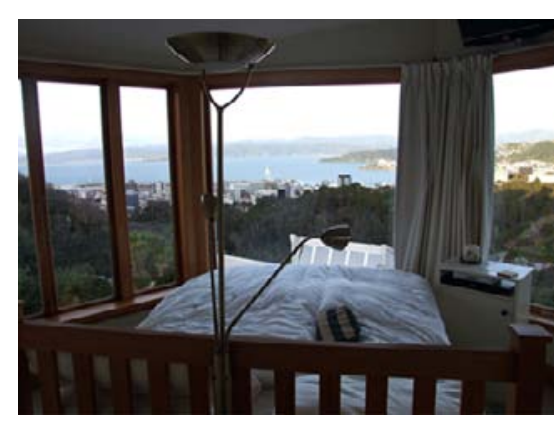

Figure 6.3: Current upstairs bedroom

Figure 6.4: 45 Orangi Kaupapa Rd

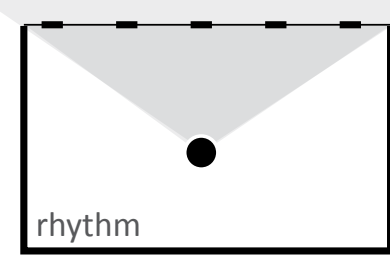

definite

framing alcove in the east side of the living room provided morning sun and harbour views where the shoreline meets the city.

The house was purchased by its current owners in the 1980s for its character ${ }^{17}$. While the alterations made a point of prioritising the panoramic views the site offered, this process was completed in a restricted manner so as to retain privacy. Retaining the existing character of house was as important to the owners, as was their wish to open up their living and dining spaces to the harbour views and morning sun ${ }^{18}$.

At the time of purchase, the living room bay window was cut one metre off the floor. Contemporary couches sat too low for this window. This led to a lowering of the glass panes to just above ground level, whilst maintaining their timber panelling and vertical nature (figure 6.2). This framing was repeated in the windows of the new dining room to the east of the living room, opening the space up to the north-east sun and views. Most of the renovations focused on an additional upstairs bedroom. Leading from the new dining area, the upstairs bedroom offers a 180 degree panorama of views over the harbour through a large picture window (figure 6.3). Privacy is achieved largely by the elevated nature of the upstairs addition

Little attention was paid to the south-west part of the house during the alterations. The introduction of west facing windows brought views of the back garden; little more was attempted as privacy from nearby neighbours was an issue. However, internal glass doors were placed in the entrance hall generating long views through the house, bringing a hint of the back garden into the living areas. While the owners note that it is the nearby garden areas of the site that generate a greater sense of space within the house, the views across the harbour offer the most enjoyment (Crossan). The daily variation in the colour and nature of the sea keeps the owners interested in the outside.

\section{Ponsonby Rd}

Karori 1949 (alteration in 1972, 1996 and 2007)

From its initial construction in 1949, multiple renovations in this house have extended and reconfigured the built footprint on this sloped and narrow site. With a strong eastern focus and a wide panoramic outlook of the city, harbour and eastern hills, the main difference from 45 Orangi Kaupapa Rd is its lack of foreground and middle ground interest. The land drops away to reveal distant views of the city, harbour and mountain ranges. The main living areas remain on the top floor and give an elevated focus on the distant views far beyond the property.

The first two alterations made to this home were extensions to the back of the house. The 1996 renovations saw a deck added to the front of the house, in an attempt to further connect with the extended outlook.

The present owners bought the house in 1999. A house with a view was not specifically sought, but the external outlook has become the main feature in the latest alterations. The owners note that the harbour and mountain ranges beyond are the main features of the view. The movement of ferries and boats, changes of weather and events at the stadium or waterfront retain the interest of the owners, offering a sense of awareness and understanding for the happenings of the outside world (Stonyer).

The latest alteration created a long view through the length of the house through the open and sparse layout of the living areas.

The view to the east is framed by a floor to ceiling glass wall extended beyond the eastern periphery of the house (figure 6.6). The architect considered this model of a bay window the main feature of the house, his attempt to place the clients in the view (Melhuish). Far from two dimensional, the view wraps around the corner glass, surrendering the interior to the outside.
Figure 6.5: Street elevation before latest alterations

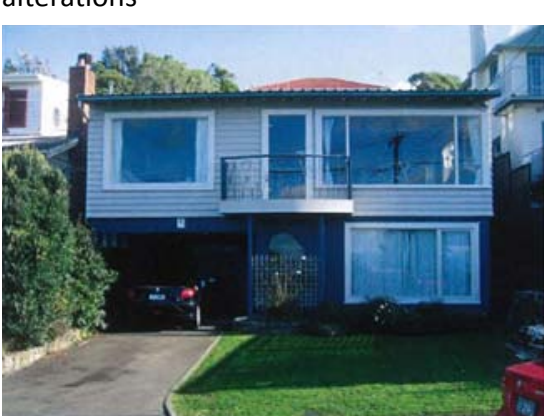

Figure 6.6: Street elevation after latest

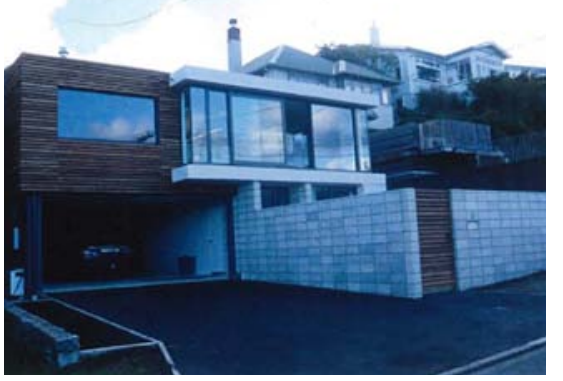




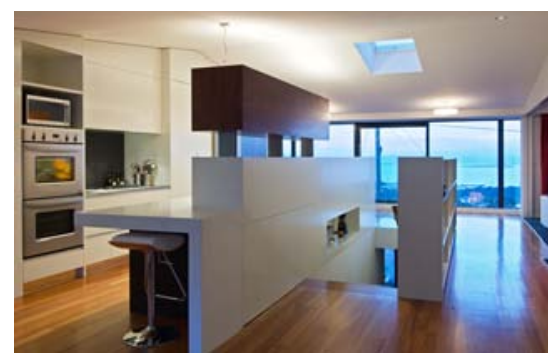

Figure 6.7: View through length of hous

Figure 6.8: 58 Ponsonby Rd

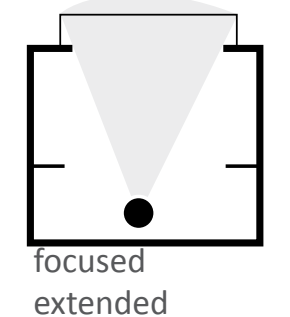

epth

19 Providing privacy for the ground floor guest room, the garden wall is barely noticeable from the first floor. This reinforces the sense of separation upstairs from the foreground.

${ }^{20}$ This focus is controlled upon entry by storage cabinets running either side of the stairway opening. These units and other internal joinery within the house act as blinkers; both visually and physically channelling guests as they enter and move around the main spaces of the house (figure 6.7).

${ }^{21}$ Previous alterations saw extensive windows along the north elevation, however, these were generally covered by sheer curtains as privacy from next door neighbours was an issue. The original main entrance into the house was through an external staircase on the southern side of the house. This staircase remained unt the most recent alterations.
In a distinctly different mode, the front room to the south is an enclosed room with a tightly framed window within the wall. Described by the architect as a picture on the wall, the view in this space has become flat, perceived as a representation of the outside (Melhuish). A lower ceiling level reinforces this sense of enclosure. The harbour views through the window act as an internal feature, similar to the television which sits opposite it. A vertical slot has been cut at the southern end of the lounge, in line with the neighbour's brick chimney. This window, generating little light and no ventilation, has simply been placed to provide a glimpse of the close set nature and use of materials of the next door house. This window is one of several slot openings around the house indicating points beyond the external walls.

The dwelling entrance is concealed behind a high concrete block fence, which separates the house from its city and harbour views ${ }^{19}$. Through the front door and the westward ascent to the first floor, the eastern view is not appreciated until the guest has reached the first floor and turned a full 180 degrees ${ }^{20}$. While previous alterations attempted to open up the house to the north and south ${ }^{21}$, the current alteration is entirely east-west focused, emphasising the length of the site.

\section{Marine Drive}

Eastbourne 1999

The third case study is an architect's home built on a vacan site along the shore of Days Bay. The site was chosen by the architect for its across-the-harbour prospect of Wellington city. From its conception, the main priority of the house has been its relationship with the view.

The four stories of the house climb the cliff edge from the road. Built between the rock face and water, the house has cave-like spaces as well as a large degree of focus on the harbour view.
The architect describes this dialectic as the outcome of both a battle for external privacy as well as internal privacy, sought by members of a large family (Mills). Most of the internal walls are simple partitions. They are non-structural, allowing for removal at a later date.

While all levels have a view, the two bottom stories display a greater level of enclosure, as a variety of children's bedroom and play areas are situated within these spaces. In the third floo living room there is no visual connection to the road. Instead floor to ceiling glass panes create an impression of floating over the water. With the kitchen incorporated into this space, the living room becomes the most visited space in the house. The view in this room creates an impression of space, suggesting the room is part of something larger than itself.

The connection between floor and wall to window has been concealed completely, minimising interruptions in the view (figure 6.9). The window structure has been designed within the body of the floor and wall. The architect describes his windows as embracing, warping and composing the view (Mills). The placement of the furniture against the walls reinforces this notion. By contrast, in the lower levels, windows are selectively placed to ensure privacy.

As in the other case studies, water is described as the most important aspect of a view. The movement, weather pattern and reflections of light provides a changing atmosphere throughout the day and night, described as "amplifying the environment" (Mills). The only negative comment about their home that could be extracted from the owners was that due to this level of transparency between house and shore, they now never physically visit the Days Bay shoreline.

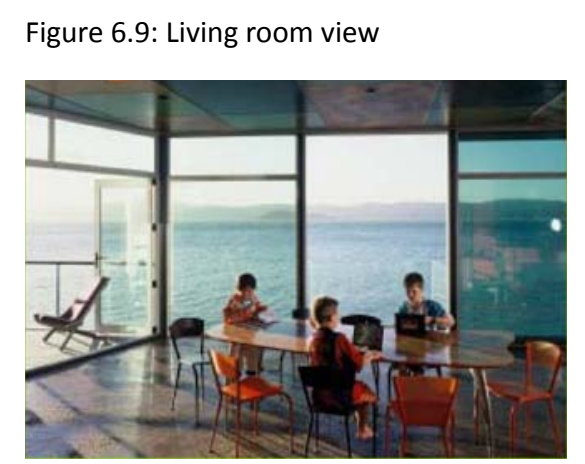

Figure 6.10: Deck off living room

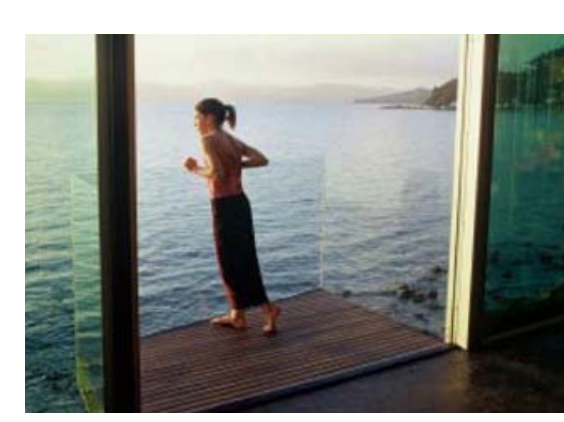

Figure 6.11: 731 Marine Dr

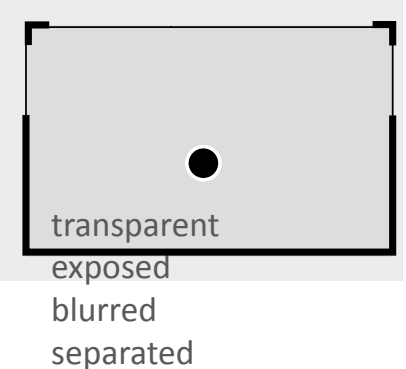




\section{Conclusion}

This chapter offers the opportunity to examine specific design decisions made by an architect with respect to a view and the personal connections clients subsequently have to the views within these spaces. In each case study, common and distinctive responses to a view are presented. This section of the research has highlighted the reality of design decisions, including the constraints and opportunities provided by a site, an owner's requirements or both parties' interests in respect of a view, and underlying attitudes to the views in question. In all three houses, the outcome of the architectural design is a view which is a dominating feature of the whole house.

Within the three houses, there are two common themes: the tension between exposure and privacy, and the way that a view becomes a metaphor for life outside, creating an impression of being connected to a wider world. In the first two studies, a house with a view was not specifically sought but views have become a major feature of the house. In the third study, the desire for a view determined the purchase of the site and the design of the house.

The two dichotomies of privacy/exposure and connection/ separation as well as the individual design approaches of the three architects in this section offer practical techniques for the following design chapters. 


\section{Chapter 7:}

\author{
Design Argument
}

In a commentary about landscape art, Francis Pound proposes that, from realist to abstract artistic styles, paintings "stain the window, they all impose their shapes and colours on what little (if anything) can be seen of the world through that glass" (Pound, Frames on the Land 12). A stain is not necessarily negative, Pound is simply noting the biased nature of art and that in every artistic process, the decisions an artist makes will affect the manner in which their work's themes are expressed.

The following chapters of this thesis explore how in designing interior spaces from which to see an outside view, an architect creates a similar "stain".

It is demonstrated in this thesis that there is a similarity between a landscape depicted within a painting and views of the land framed by a window. At its simplest level, the resemblance between the two lies in the pictorial manner in which a landscape is portrayed. By its nature, a window is a frame for a view. More than this, the portrayal of a view creates a relationship between a view and a viewer. Finally, similar to artists, this thesis argues that architects can influence the manner in which a landscape is depicted through a window.

The contention presented here is that domestic architecture can and ought to be more than a platform for displaying a prospect of the outside. Architecture can offer an expression of a relationship between an inside space and an outside world. 
To achieve this, it is important that consideration is given to architectural elements of a house that could contribute towards this relationship with a view. To achieve a coherent connection between aspects of a house and a surrounding landscape, a balance is required between the interior spatial layout, window conditions and external prospect. It is suggested therefore, that all the conditions of the house and site ought to be considered, as all could be relevant to an experience of a view.

In line with Beatriz Colomina's statement, "architecture is not simply a platform that accommodates the viewing subject. It is a viewing mechanism that produces the subject" (Colomina 83). Architects create spaces which, through their architecture, alter an expression of an external landscape. This thesis proposes that architects can create an active link between the interio and exterior, beyond simply supplying the shelter for an allencompassing view of the outside. The connections between art and an appreciation of a view suggest a closer examination of artistic experience might assist in understanding how a view might be expressed.

Often artists evoke a sense of the non-visual qualities within a depicted landscape. Through an abstraction of form, many modern artists explore aspects of landscape beyond the sphere of vision or through an original perspective. This can occur in many forms; it can be a particular context, focus or style. From an understanding of an artistic process of creation, this design argument examines the ability for this artistic treatment of landscape to be transferred into an architectural space.

The design component of this thesis explores this argument in two parts: firstly an analysis of the relationship between a view and its artistic delivery, as presented through the work of four artists. This experimentation leads into a final design component, which incorporates all previous research into the design argument.
Part one is introduced through four research studies into nineteenth and twentieth century New Zealand landscape artists. Drawn from an understanding of their various styles, motivations, processes and techniques, their perspectives on landscape are translated into an architectural context. The outcome of this exercise is four spaces that each embodies the atmosphere and themes of a particular artist in respect to their landscapes.

Part two of this design process tests original design thought - a personal "stain" or bias - against the research analysis. It aims to present an argument for a more considered role for an architect in designing a view. In this new endeavour, an architect mediates between the external and internal landscapes in a way that enhances the relationship between a view and a viewer. A view is no longer a passive object within a house, it is part of the experience of a viewer within a house.

The outcome of this phase will be two residential dwellings, one that separates a view from a viewer and a house of opposite and contradictory intentions, proposed as a fresh perspective for New Zealand. The second design will endeavour to alter the passive role of an extended view so that a view and a viewer are connected. The two houses will express two opposing notions of landscape through their architecture, enabling a critique of the success of the designs.

Similar to the programmatic decisions, the choice of site was made for its prominent nature and opportunities of view. 


\section{Chapter 8:}

Site selection and analysis
The site at 71 Hawker Street sits on a prominent north-west facing incline of Mount Victoria in Wellington. It slopes down from street level and consists of two lots making the site twice as wide as surrounding sites. An abandoned and derelict villa originally built in 1897 stands on the north side of the site. A large panoramic view from north Kaiwharawhara, across the city to Mount Cook and Brooklyn is offered from the site. Neighbouring houses cut off part of the view lower down the site, however, for the majority, a wide expanse of harbour, city, suburb and western hills pervade a visitor's view.

It is assumed the site is vacant in part because it sits to the southwest side of St. Gerard's Church and Monastery. The church is slightly uphill from number 71 and casts a shadow across the site for a large majority of the day (figure 8.11). Due to the heritage status of the Monastery, various council design restrictions have been placed on this part of Mount Victoria. Not only a platform for some of Wellington's most prized views, St. Gerard's Church and Monastery is a view in itself.

Regulations of roof pitch, building grain style, and window conditions have been formed in an attempt to retain the suburb's existing character (Wellington City Council, "Mount

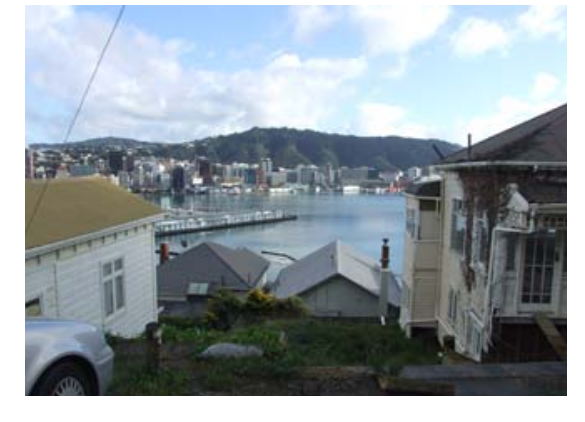

Figure 8.1: View across the site

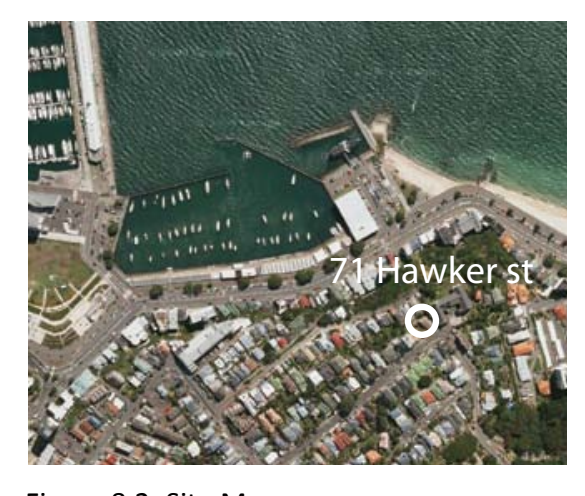

Figure 8.2: Site Map 
Victoria North Character Area Design Guide"; Wellington City Council, "Residential Area Rules").

This site is employed in both the series of artist studios and house designs of the next two chapters. The site is relatively unimportant for the first phase, it supplies a simple set of parameters for the four studio spaces. Within the second design, the site plays a more significant role. It is fully integrated into the design and essential to its execution.

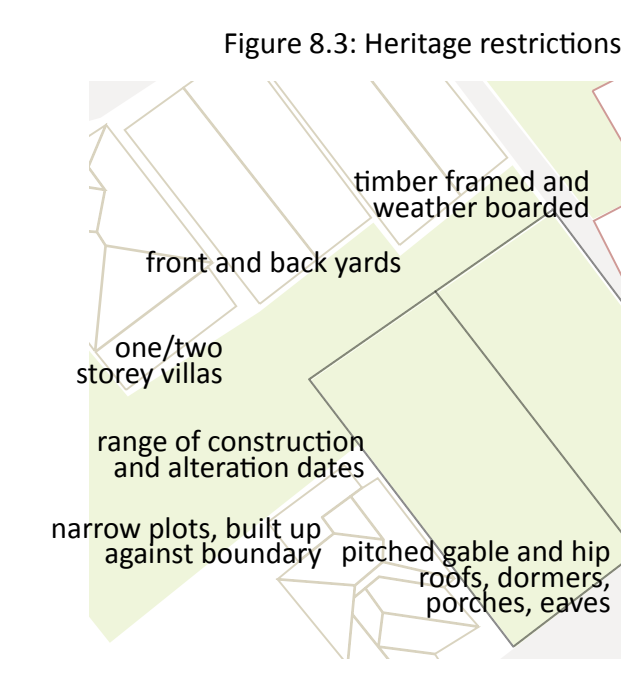

Figure 8.5: Site section

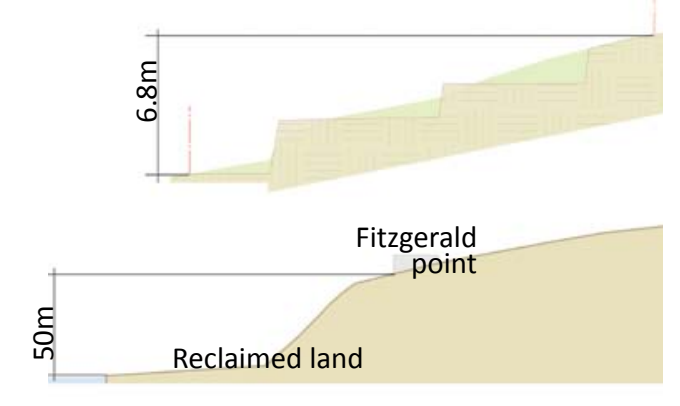

Figure 8.4: Existing building grain

1. long narrow sections orientated to the north or north west and a minimal distance between buildings and boundaries

2. Sloping roofs of different styles

predominate, creating a noticeable

pattern which is complementary to
Gerard's

3. Existing buildings incorporate
openings that are punctuated. There are no large expanses of sheet glass, as

these mostly appear in nearby areas where newer buildings have been built
for the views

Figure 8.6: Site typography

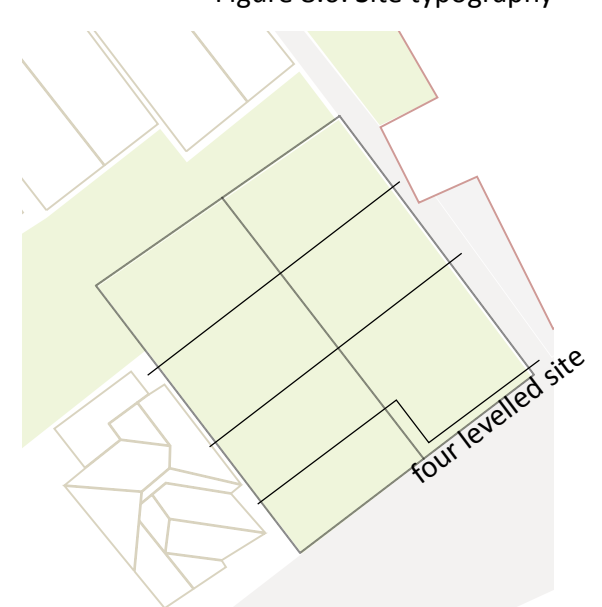

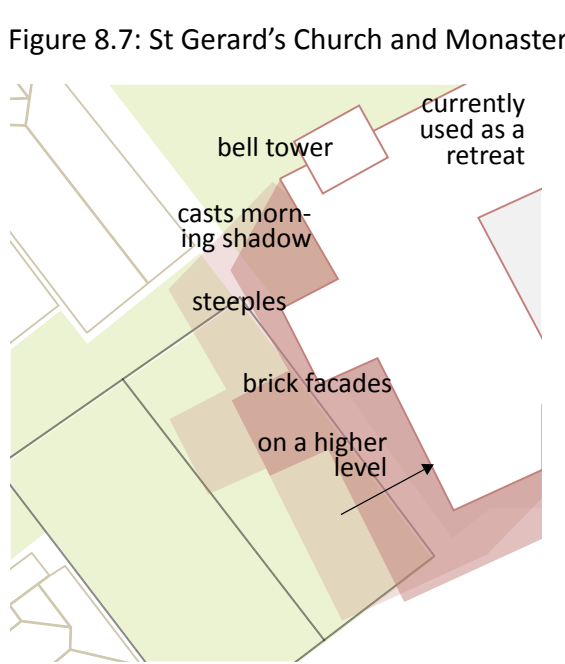

Figure 8.8: Existing villa

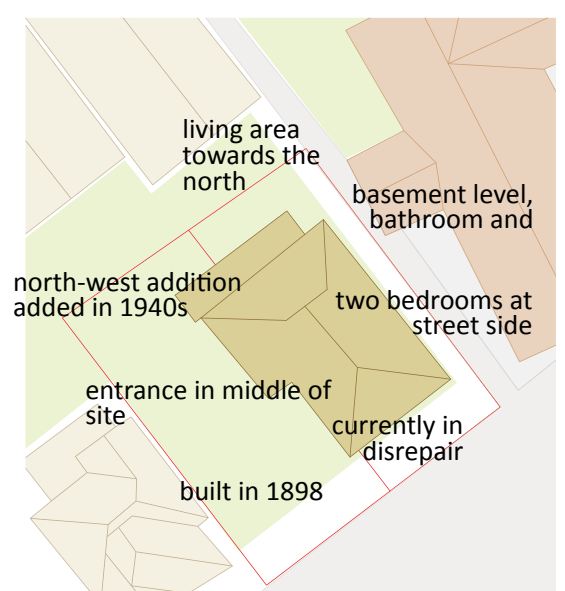

Figure 8.9: Access ways

Figure 8.10: Sights

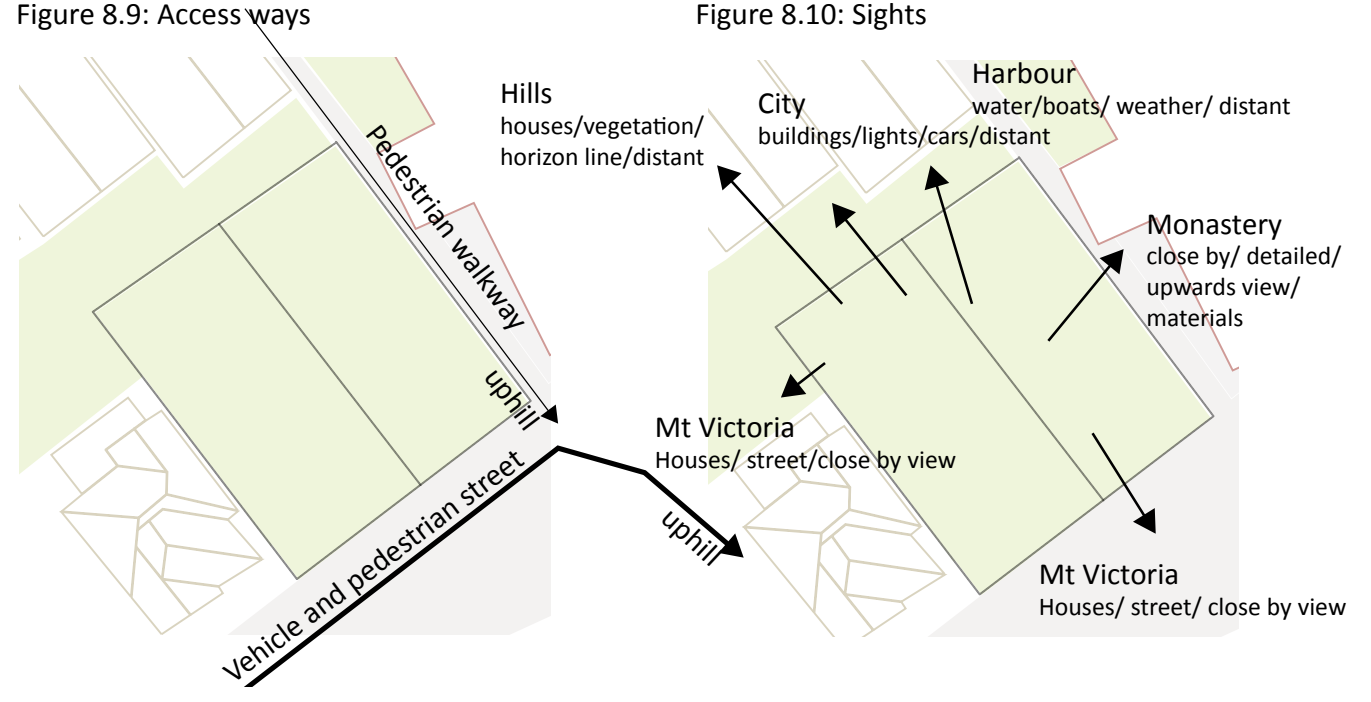

Figure 8.11: Solstice sun paths

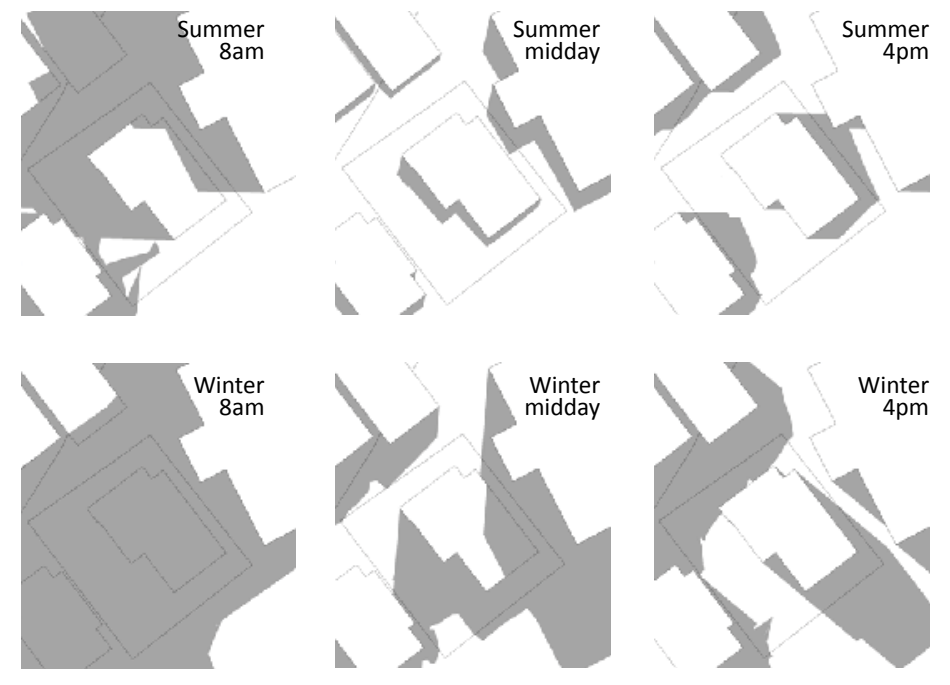




\section{Chapter 9:}

\author{
Design part one \\ Artist studies
}

The following studies demonstrate an understanding of the motivations behind four prominent New Zealand artists in the nineteenth and twentieth century. The first stage of this process has been to dissect information from a variety of texts which discuss the artist or their work, drawing out information on their beliefs, themes, techniques and processes that could aid in translating their 'bias' of a landscape into an architectural language.

The second stage has been to breakdown the information into a form that allows a translation of ideas from an artistic language to an architectural language.

The final stage is implementation on site. A series of development sketches, as well as an end scenario, deliver a final architectural design that incorporates their artistic themes. Each artist has been studied and then translated onto the site independently, with respect to their scale, spatial conditions and view content. They highlight four unique design processes as well as four varying relationships with New Zealand landscapes. 


\section{John Gully}

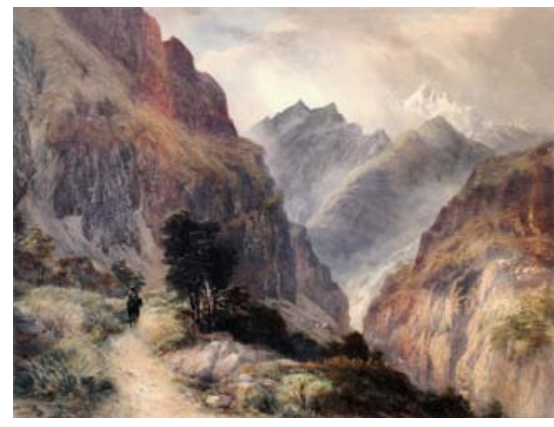

Figure 9.1: 'In the southern alps'

Born in Bath, England in 1818, John Gully immigrated to New Zealand with his family in 1852 . While described as the most successful New Zealand artist of his time, Gully is noted most for the public popularity of his work as "non-intellectual prettiness" (Gully 106; Johnstone). Both a realist and romantic, Gully was careful in colour and form to faithfully portray New Zealand, yet he was willing to alter a view or small detail if it improved a painting (Gully). For Gully the foreground was where he could intervene the most. His small manipulations of scale, colour and order increased the illusion of depth and often drew out the foreground from the rest of the painting (McLean).

The themes in Gully's painting are clear and consistent: the insignificance of man before the vast and untouched landscapes (Ocula; Tongarewa). His use of light, particularly the changing light of dawn and dust, has been praised in its attempt to smooth the harshness of the landscapes he painted. This technique reinforced a sense of familiarity and comfort within his paintings, as opposed to the awe or terror a viewer might have observing these imposing and unknown landscapes (Gully). Similar to other romantic and picturesque painters, he rendered a landscape that offered a sense of freedom to transport a viewer.

\section{Translation}

\begin{tabular}{|c|c|c|}
\hline Categories & Gully's techniques & Translation \\
\hline Light & $\begin{array}{l}\text { Daybreak and dusk lighting - } \\
\text { changing light } \\
\text { soft, misty/atmospheric quality }\end{array}$ & $\begin{array}{l}\text { Orientation, window } \\
\text { position, size, lighting }\end{array}$ \\
\hline Colour & $\begin{array}{l}\text { Sombre, subtle, quiet tones, } \\
\text { occasional contrast colour }\end{array}$ & $\begin{array}{l}\text { Interior colouring and } \\
\text { materials }\end{array}$ \\
\hline Composition & $\begin{array}{l}\text { Clear foreground, middle ground } \\
\text { and background, sense of unity } \\
\text { between them }\end{array}$ & $\begin{array}{l}\text { Window placement and } \\
\text { framing, (potential use } \\
\text { of internal foreground) }\end{array}$ \\
\hline Themes & Isolation, insignificance of man & $\begin{array}{l}\text { View focus, design of } \\
\text { surrounding space }\end{array}$ \\
\hline Style & $\begin{array}{l}\text { Realist / topographical } \\
\text { romanticism / sentimentalism/ } \\
\text { picturesque }\end{array}$ & $\begin{array}{l}\text { View focus, design/ } \\
\text { atmosphere of space }\end{array}$ \\
\hline Content & $\begin{array}{l}\text { Wide, expansive views } \\
\text { Landscapes, seascapes, } \\
\text { mountainscapes }\end{array}$ & $\begin{array}{l}\text { Window size and } \\
\text { proportion, view focus }\end{array}$ \\
\hline $\begin{array}{l}\text { Human } \\
\text { element }\end{array}$ & $\begin{array}{l}\text { Unpopulated land, unobtrusive } \\
\text { animals, spectator people, } \\
\text { buildings and boats - used for } \\
\text { scale }\end{array}$ & $\begin{array}{l}\text { View focus, spatial } \\
\text { programme }\end{array}$ \\
\hline Painting size & $\begin{array}{l}\text { Landscape paper, mostly 50- } \\
100 \mathrm{~cm} \text { wide. }\end{array}$ & $\begin{array}{l}\text { Window size and } \\
\text { proportion }\end{array}$ \\
\hline \multirow[t]{2}{*}{ Scale } & Human view point & $\begin{array}{l}\text { Window placement, } \\
\text { design of space }\end{array}$ \\
\hline & Sharp, detailed, textural & $\begin{array}{l}\text { Framing and Interior } \\
\text { material and texture }\end{array}$ \\
\hline Atmosphere & $\begin{array}{l}\text { Welcoming, freedom, openness, } \\
\text { grandeur }\end{array}$ & $\begin{array}{l}\text { Colouring, materials and } \\
\text { spatial design }\end{array}$ \\
\hline Depth & $\begin{array}{l}\text { Invention of foreground - its } \\
\text { relationship with background, } \\
\text { contrasting colours }\end{array}$ & $\begin{array}{l}\text { Site placement, defined } \\
\text { foreground, interior } \\
\text { materials/colouring }\end{array}$ \\
\hline
\end{tabular}

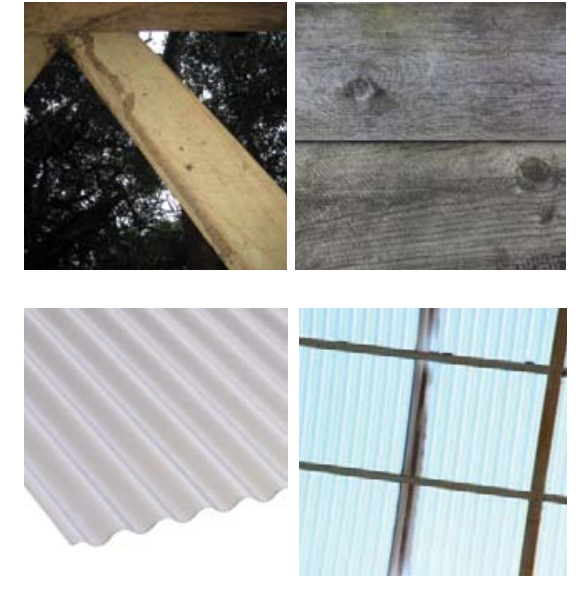

Figure 9.2: Material study

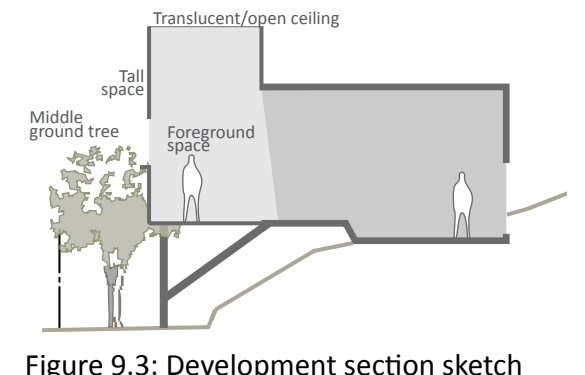

Figure 9.3: Development section sketch

Figure 9.4: Development site plan sketch

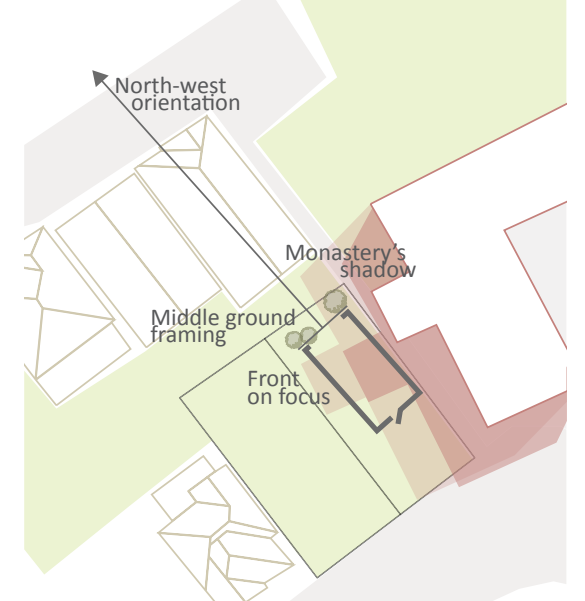




\section{Implementation}

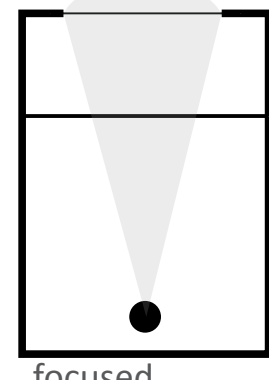

separated

controlle

internal foreground

Figure 9.5: John Gully diagram

The next site-related decision was to place the space deep within the shadow of the monastery, contrasting the bright and

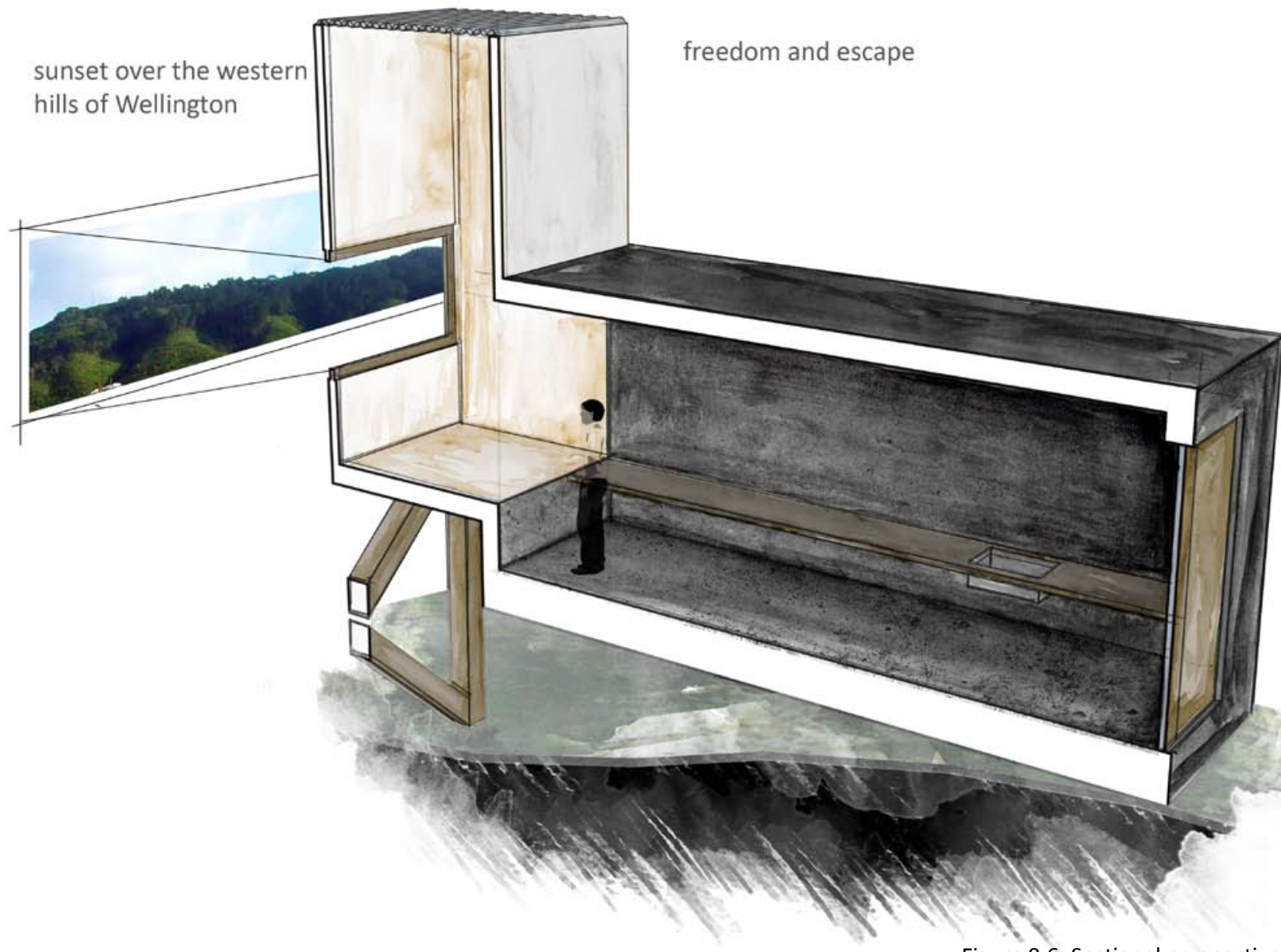

Figure 9.6: Sectional perspective clear view of the mountains with a shady interior. This pulls the focus of the space beyond the periphery of the studio, inviting an artist's attention into the open space offered by the view beyond.

A direct and single viewpoint through the space, reminiscent of Gully's paintings, is translated into the long, narrow nature of the space with one entry opposite the only visual escape from the interior of the studio.

A wide horizontal opening captures a very specific section of the view; its flatness is contrasted with the three-dimensional nature of the distinct interior foreground. To reinforce the role of the artist as a spectator of this landscape, a separate space has been created in front of the view in the main artist's area. The artist views the outside from a lower level, close to the window, which stretches up and out beyond the box shaped space. This foreground space, inaccessible to the artist, opens up the sky by a high transparent ceiling, inviting light into the raised area only. A simple timber frame outlines and contains the view, cutting the suburbs and city from sight. It reinforces the sense of separation felt as a spectator views the distant hills.

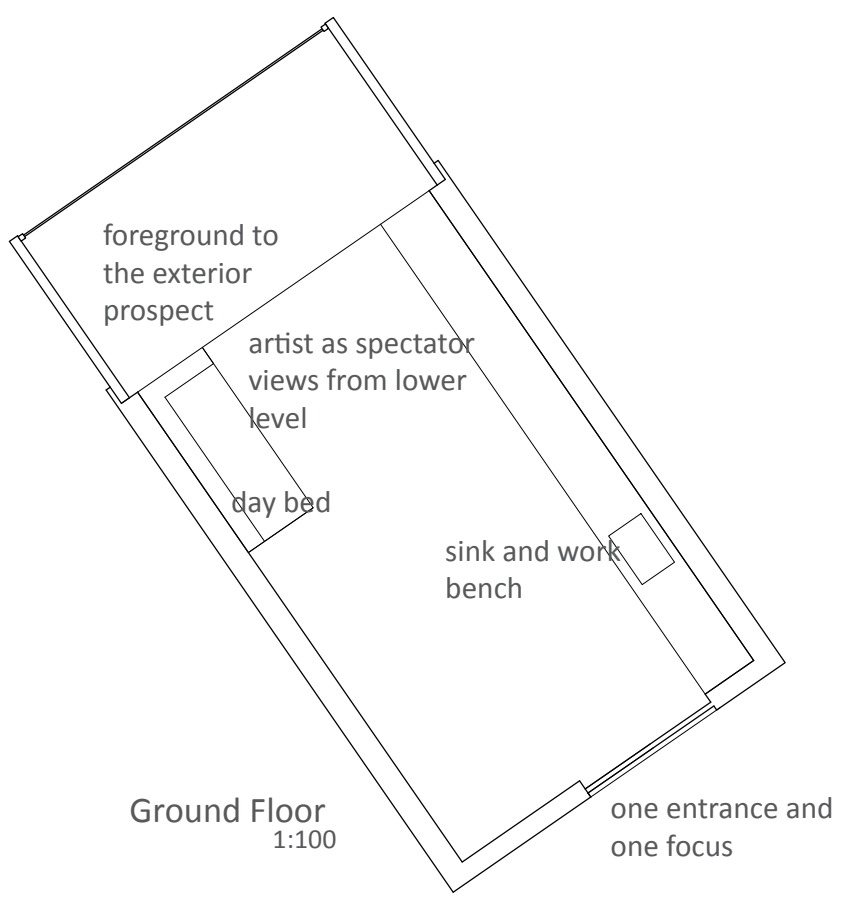

Figure 9.7: Floor plan
Figure 9.8: Thumbnail perspectives
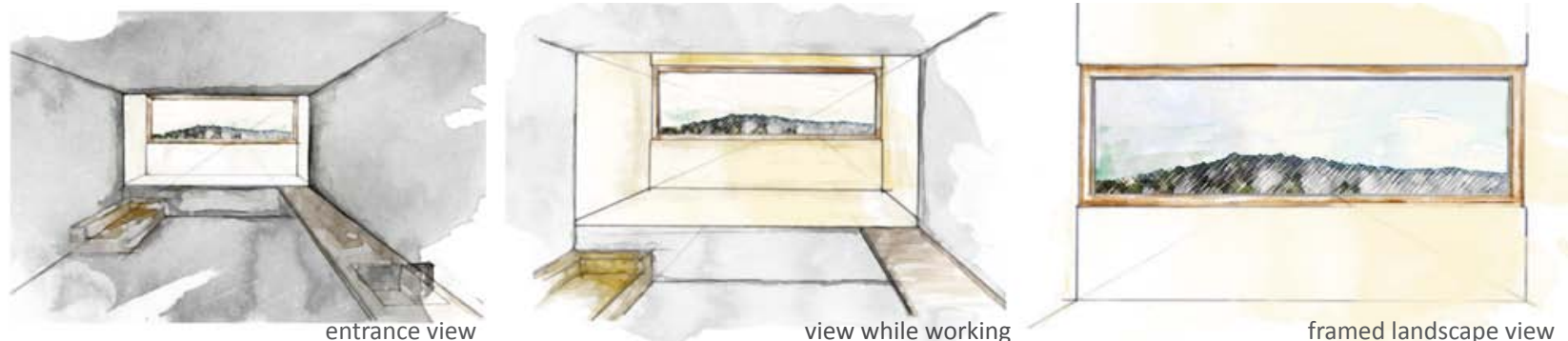


\section{Rita Angus}

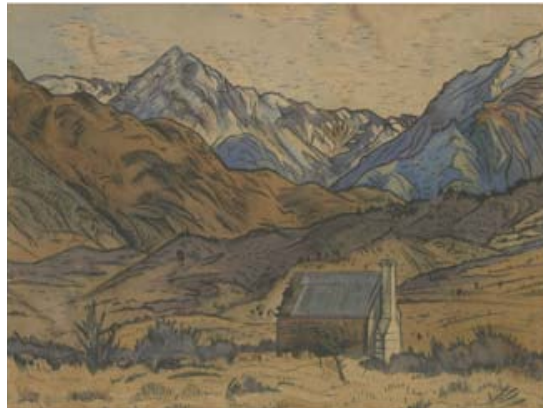

Figure 9.9: 'Mountains, cass'
Rita Angus was born in Napier in 1908. Unlike John Gully, who had various careers before being able to finance himself in his later years as a full-time painter, Angus was supported by her family from a young age. Her determination and fierce independence, define her and her work, and she is recognised as leading twentieth century New Zealand artist (McAloon). Not only interested in landscapes, Angus is also well-known for her portraits and nature studies. She attempted to paint the life in everything she saw. She began painting at a time when there was a demand for a New Zealand style, an original approach to landscape art rooted in New Zealand attitudes, as opposed to European traditions (McAloon)

Her personal independence suited the time in which she was painting. She borrowed techniques from Japanese print making Cubism and other modernist approaches, never following any style exclusively or losing her individuality to the ideals of other great artists (Paul). While her content and level of abstraction varied throughout her career, her body of work holds together through "her close observation of the world around her and her deep feelings for nature" (McAloon 12). Described as painting "the mystery of the ordinary", Angus sought the colours, geometries, patterns and light of places and people around her (McAloon 16). Her paintings' themes reflect the "simplicity of her life [and] her insistence on making-well"; from questioning the intervention of humans on the landscape to ideas of peace and compassion (McAloon; Paul).

\section{Translation}

\begin{tabular}{|c|c|c|}
\hline es & Angus' tec & Slation \\
\hline ight & Clear, crisp, stark light & $\begin{array}{l}\text { Orientation, window } \\
\text { position, size, lighting }\end{array}$ \\
\hline Colour & $\begin{array}{l}\text { From muted to bold tones, } \\
\text { primary colours, decorative, } \\
\text { complementary }\end{array}$ & $\begin{array}{l}\text { Interior colouring and } \\
\text { materials }\end{array}$ \\
\hline orm & $\begin{array}{l}\text { Geometry, triangular and } \\
\text { rectangular, rhythmic patterning, } \\
\text { outlined, sharp, hard edged, } \\
\text { interlocking, displacements and } \\
\text { conjunctions }\end{array}$ & Design of internal spac \\
\hline mposition & $\begin{array}{l}\text { Layered, internal logic, balanced } \\
\text { and unified fore, mid and } \\
\text { background }\end{array}$ & $\begin{array}{l}\text { View focus, design of } \\
\text { surrounding space }\end{array}$ \\
\hline emes & $\begin{array}{l}\text { Isolation, peace and compassion, } \\
\text { mystery of the ordinary }\end{array}$ & $\begin{array}{l}\text { View focus, design/ } \\
\text { atmosphere of space }\end{array}$ \\
\hline yle & Independent, abstract & $\begin{array}{l}\text { Window size and } \\
\text { proportion, view focus }\end{array}$ \\
\hline ontent & $\begin{array}{l}\text { Landscapes, buildings, people, } \\
\text { portraits }\end{array}$ & $\begin{array}{l}\text { View focus, spatial } \\
\text { programme }\end{array}$ \\
\hline $\begin{array}{l}\text { Human } \\
\text { element }\end{array}$ & $\begin{array}{l}\text { Human intervention with } \\
\text { landscape, interested in people }\end{array}$ & $\begin{array}{l}\text { View focus, window } \\
\text { placement, spatial } \\
\text { programme }\end{array}$ \\
\hline cale & $\begin{array}{l}\text { Birds eye, multiple points of } \\
\text { view, micro to the macro }\end{array}$ & $\begin{array}{l}\text { Window placement and } \\
\text { size }\end{array}$ \\
\hline mosphere & $\begin{array}{l}\text { Vastness and distance, } \\
\text { domination of nature and the } \\
\text { impact and interference of man }\end{array}$ & $\begin{array}{l}\text { Colouring, materials and } \\
\text { spatial design }\end{array}$ \\
\hline Depth & $\begin{array}{l}\text { Colour, series of flat layers, sharp } \\
\text { and detailed in the distance }\end{array}$ & $\begin{array}{l}\text { Interior materials/ } \\
\text { colouring spatial design }\end{array}$ \\
\hline ocess & $\begin{array}{l}\text { Development of past paintings, } \\
\text { repainting and reworking } \\
\text { existing. }\end{array}$ & $\begin{array}{l}\text { Sense of growth and } \\
\text { development within } \\
\text { space }\end{array}$ \\
\hline
\end{tabular}

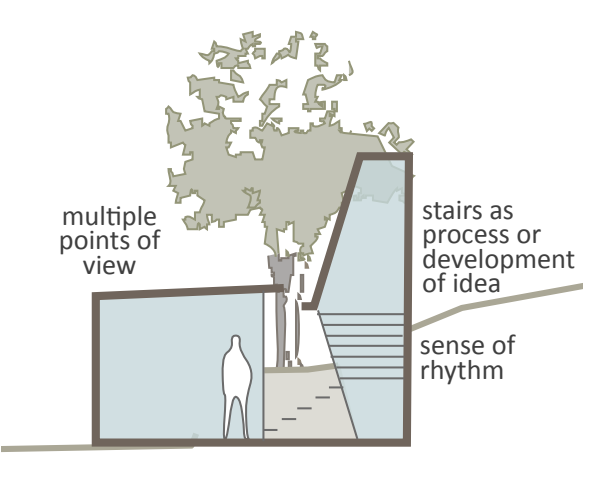

Figure 9.10: Development section sketch 1

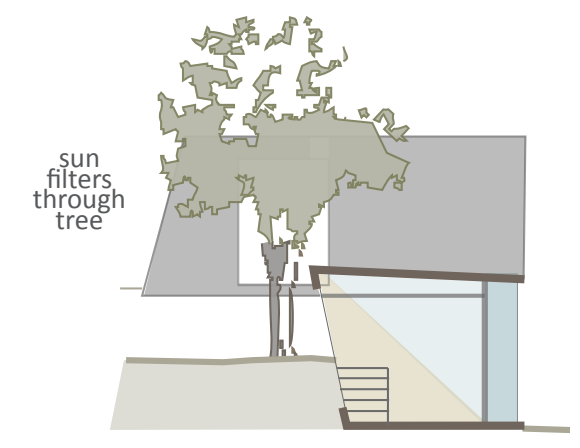

Figure 9.11: Development section sketch 2

Figure 9.12: Development site plan sketch

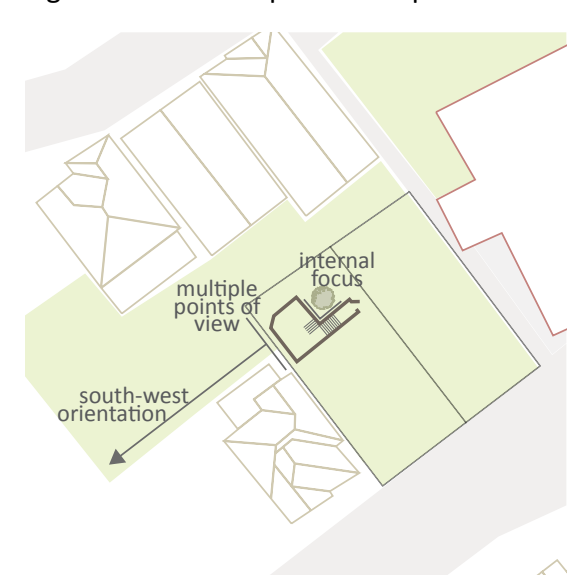




\section{Implementation}

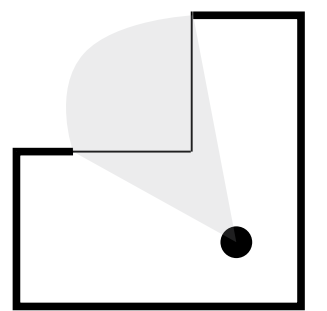

blurred

multiple view point

enclosure

proximity

Figure 9.13: Rita Angus

The notion of 'exploring the ordinary' became the basis for the Angus inspired space. The sole focus of the studio is a full comprehension of a tree. Within the space, one navigates down and around a tree which is closely nestled into the studio. An exploration of space and tree were enhanced by the north orientation, which allows sunlight to filter through the branches, giving a sense of movement and pattern to the changes in light.

The position on site was also chosen for its existing drop in ground level, suiting the two-storey nature of the space. This change in level is needed to explore beyond the usual focus of a tree. From the upper floor entrance, there is a direct view to the lower branches of the tree. As the artist descends the steps to the main area, the angles and geometries of the window cut in and out following the form of the tree, until the view from the

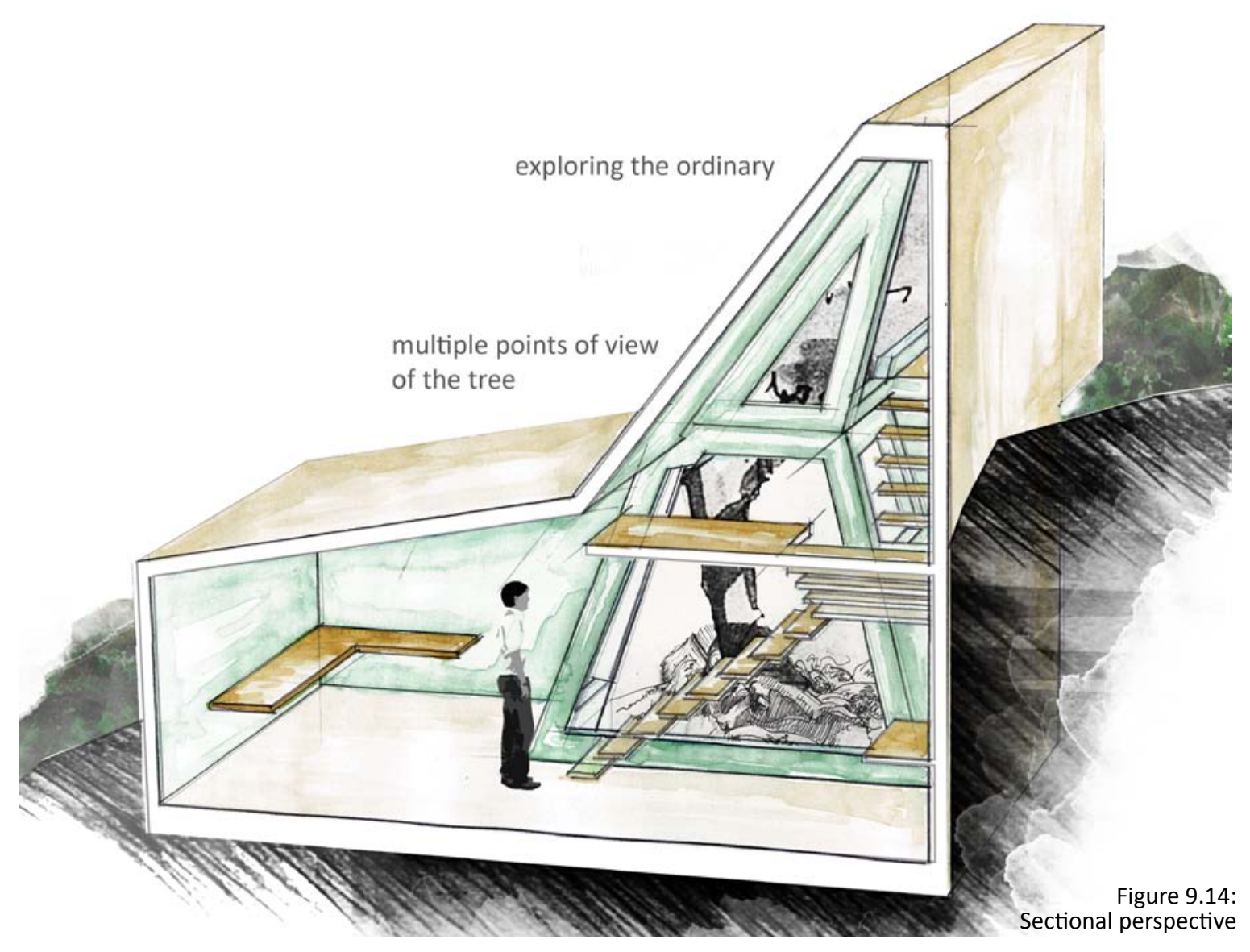

lower floor is the roots and ground beneath the tree, introducing the part of a tree typically hidden from view.

This shift in level and angle within the space relates to the multiple viewpoints Angus applied to her art. Never a direct or main view, the space offers a variety of different perspectives to view from, all slightly altering and adding to

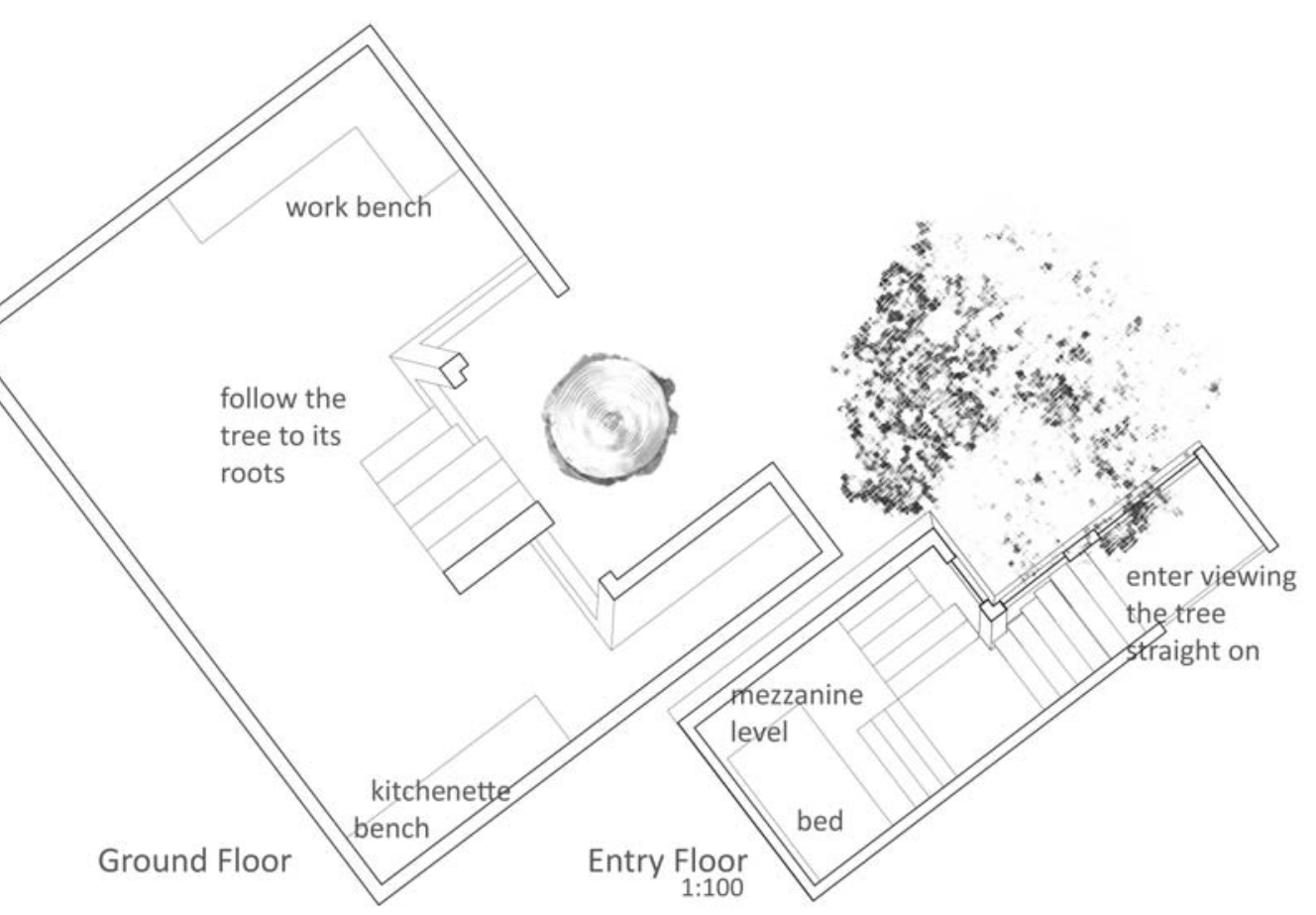

the understanding of this landscape. The three-dimensional nature of the multiple views, as an artist is transported down into the roots of the tree, is an attempt to break away from a simple observation of the land. By exploring this tree in such detail, the artist becomes connected to the tree.

The change from wall to glass pane is a flat and simple transition, similar to the layered backgrounds of Angus's work. There is no defined framing within the transition, the ambiguity in the threshold between wall and ceiling is similar to wall and window. The glass is caught between wall and tree.
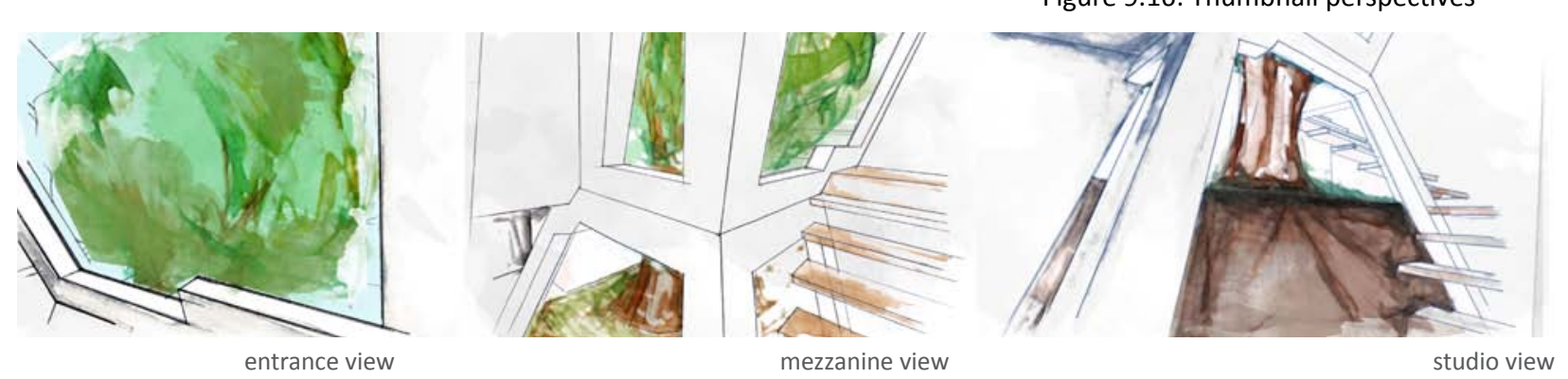


\section{Gerda Leenards}

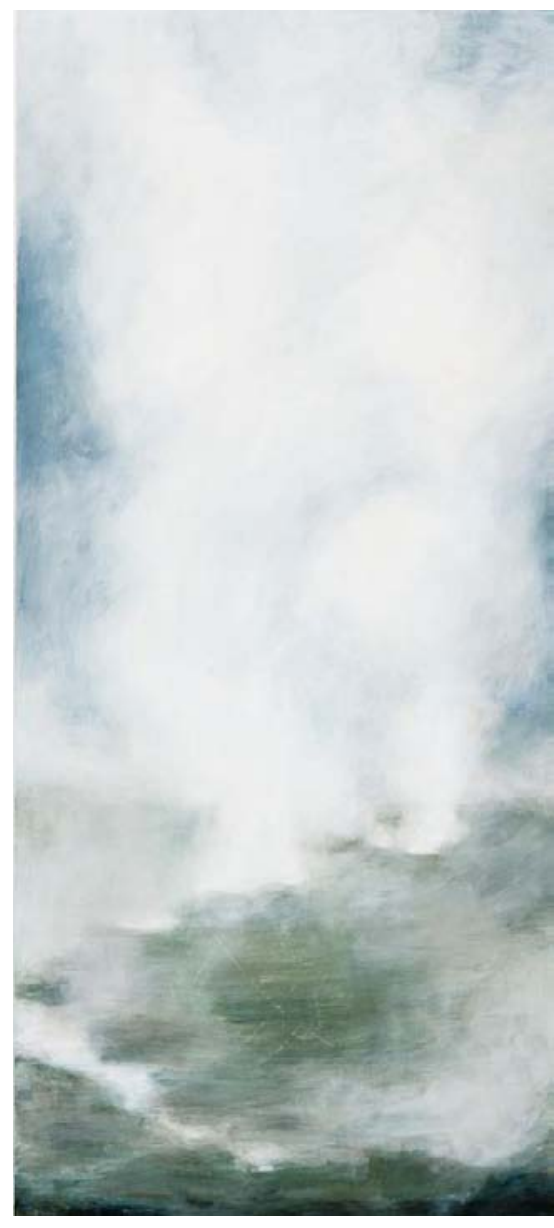

Figure 9.17: 'Silica Zig Zag' present blurring and haze.
Gerda Leenards immigrated to New Zealand from The Netherlands at the age of ten, in 1956. She worked as a draftsperson and teacher before holding her first solo exhibition in 1982 (Johnstone). With the exception of a brief studio residency in The Netherlands, Leenards has spent the majority of her working career capturing the atmosphere of New Zealand's weather and light. Described only ever as expressionist, she examines the inner qualities of her landscapes beyond visible characteristics. She looks to the history and cultural position of a landscape (Caughey). Leenards notes that the content of her paintings is only ever secondary to the emotive and abstract presence she explores (City Art Gallery Wellington). This is achieved through experimentations of light, form and an ever

Leenards' themes revolve around a notion of instability and change, drawn from a belief of the precarious nature of the earth (Johnstone 118). She uses photography to capture these instances before exploring these images in paint. A sense of movement is produced in her work as she engages with patterns of weather in the sky and its effect on the solid presence of the land. "For all the shadowy mystery of her paintings, Leenards also holds up for us an earthy familiarity, a feeling that although her landscapes are uncertain to our eye, they are solid under our feet" (Stewart 57).

\section{Translation}

\begin{tabular}{|c|c|c|}
\hline Categories & Leenards' techniques & Translation \\
\hline Light & $\begin{array}{l}\text { Changing, dark/light tension, } \\
\text { smoky and cloudy, used to reveal } \\
\text { subject }\end{array}$ & $\begin{array}{l}\text { Orientation, view focus, } \\
\text { window position, size, } \\
\text { lighting }\end{array}$ \\
\hline Colour & $\begin{array}{l}\text { Power, rawness, hazy, emotive, } \\
\text { moody }\end{array}$ & $\begin{array}{l}\text { Interior colouring and } \\
\text { materials }\end{array}$ \\
\hline Form & $\begin{array}{l}\text { Blurred, intangible, powerful/ } \\
\text { majesty, solid and grounded, } \\
\text { rhythm and patterns, tactile }\end{array}$ & $\begin{array}{l}\text { Design of internal space, } \\
\text { view focus }\end{array}$ \\
\hline Composition & $\begin{array}{l}\text { Blurred, hazy horizon line, } \\
\text { separated into sections/frames, } \\
\text { fractured, unpredictable }\end{array}$ & $\begin{array}{l}\text { View focus, design of } \\
\text { surrounding space }\end{array}$ \\
\hline Themes & $\begin{array}{l}\text { Concealment and discovery, } \\
\text { social conscious, uncertainty, } \\
\text { inner qualities of land, change/ } \\
\text { movement }\end{array}$ & $\begin{array}{l}\text { View focus, design/ } \\
\text { atmosphere of space }\end{array}$ \\
\hline Style & Expressionist & $\begin{array}{l}\text { Window size and } \\
\text { proportion, view focus }\end{array}$ \\
\hline Content & $\begin{array}{l}\text { Water, Sea and landscapes, } \\
\text { weather, climate }\end{array}$ & $\begin{array}{l}\text { View focus, spatial } \\
\text { programme }\end{array}$ \\
\hline $\begin{array}{l}\text { Human } \\
\text { element }\end{array}$ & None, undefined, alone & $\begin{array}{l}\text { View focus, window } \\
\text { placement, spatial } \\
\text { programme }\end{array}$ \\
\hline Scale & $\begin{array}{l}\text { Large, overwhelmed and } \\
\text { surrounded by }\end{array}$ & $\begin{array}{l}\text { Design of surrounding } \\
\text { space }\end{array}$ \\
\hline Atmosphere & $\begin{array}{l}\text { Power, uncertainty, } \\
\text { unpredictability, myth, awe, } \\
\text { discomfort, simplicity }\end{array}$ & $\begin{array}{l}\text { Colouring, materials and } \\
\text { spatial design }\end{array}$ \\
\hline Viewer & $\begin{array}{l}\text { Participation - both eye and } \\
\text { body, included }\end{array}$ & $\begin{array}{l}\text { Design of surrounding } \\
\text { space, window position } \\
\text { and size }\end{array}$ \\
\hline
\end{tabular}

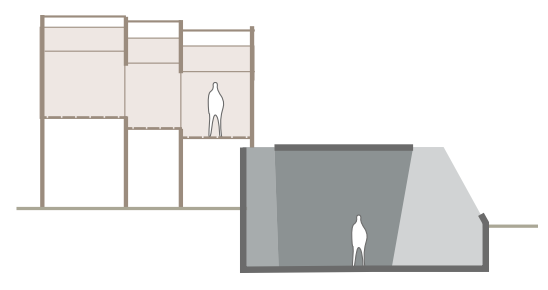

Figure 9.18: Development section sketch 1

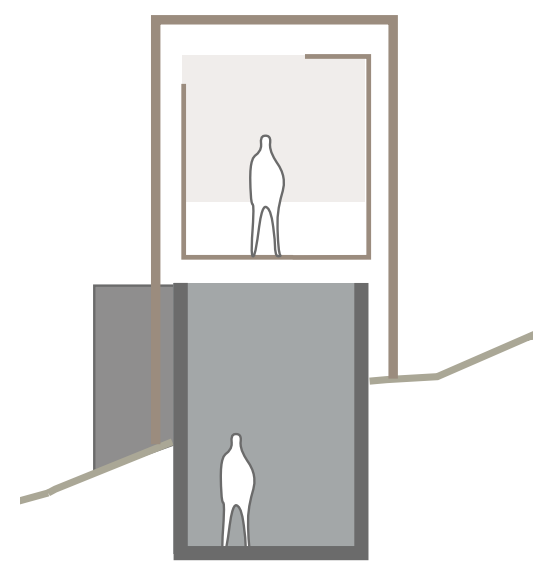

Figure 9.19: Development section sketch 2

Figure 9.20: Development site plan sketch

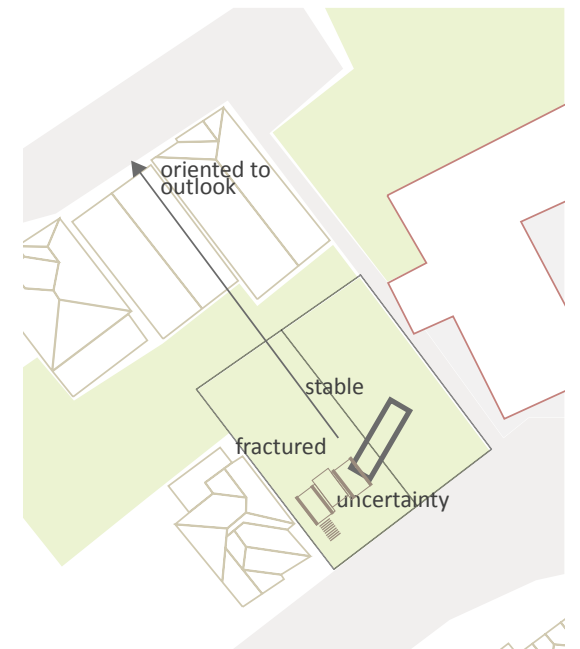




\section{Implementation}

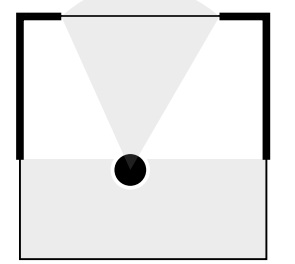

split focus

multiple view points

dichotomy

external focus

Figure 9.21: Gerda Leenards separated, similar to the change along the horizon line between the ground and the sky in Leenards' work. As the views of the top storey are skyward, the location of this building on the site is determined by the lower level. A sense of the solid and stable in the ground floor suggest a visual connection to the neighbouring St Gerard's monastery, which influences much of the studio's position on site.

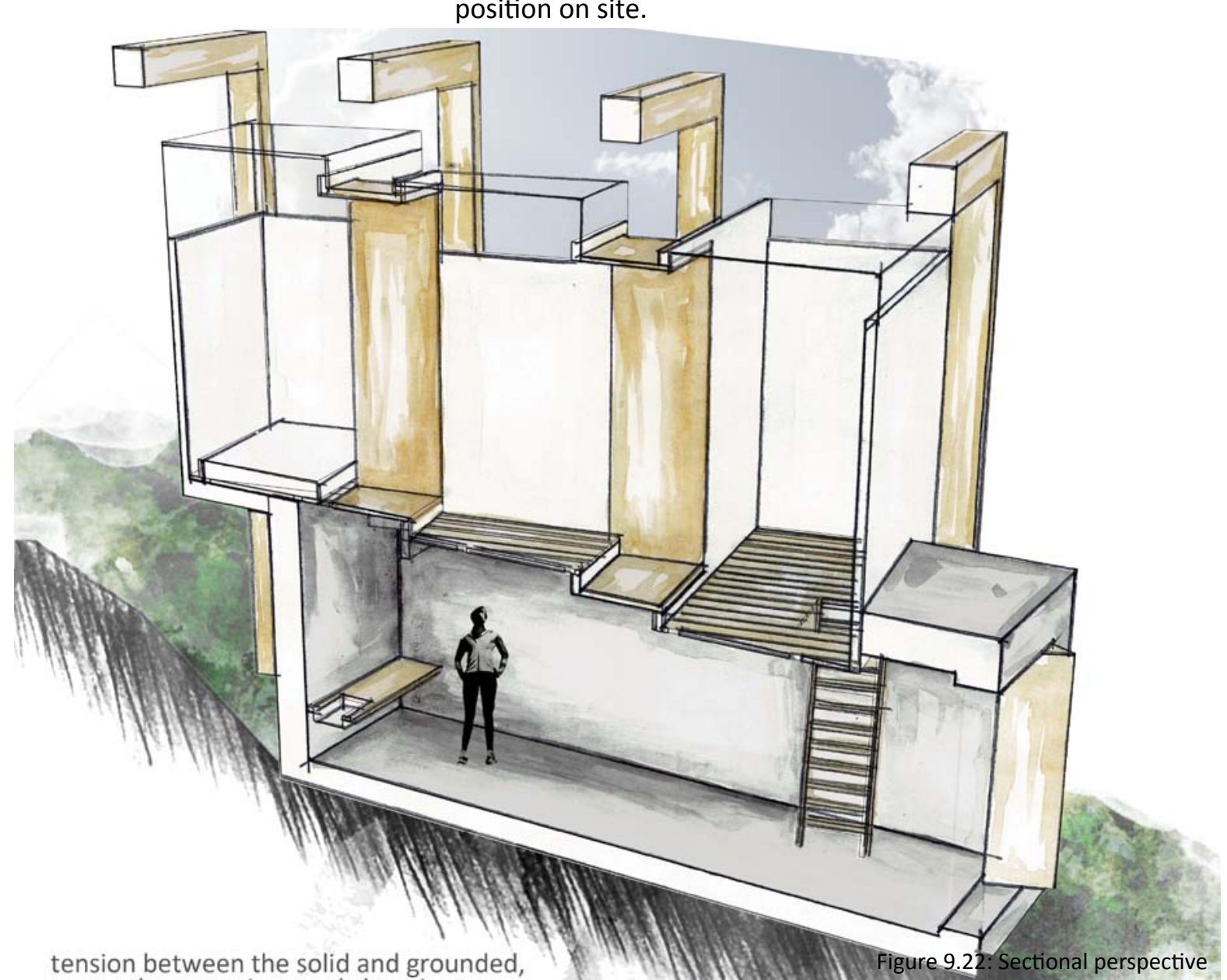

A thick concrete box with an opening at the monastery end delivers a close-up view of a longstanding brick pattern down the length of the southern facade of the neighbouring building. Yet as one enters the space, the monastery hidden, it is the light and sky views filtering through timber floorboards that capture the attention of the artist as three structures float above the concrete walls. Although this threshold between the two parts

of the studio hints at the tension between the two opposites, similar to Leenards' paintings, it is through a blurring of this threshold that the tension is partly dissolved. One storey folds into the other - the first floor rests on the grounded structure, supported from above by a series of timber frames and steel wire. This upper level, separated into three independent structures, each lifted higher into the sky, gently flex in the wind. Walkways slide between the spaces while a glass roof opens up to the sky. Viewed through the wide gaps in the flooring, the grounded space below remains dark and rigid, its presence felt as the artist walks across the swaying top space.

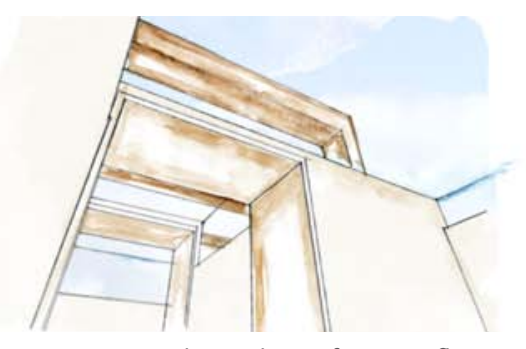

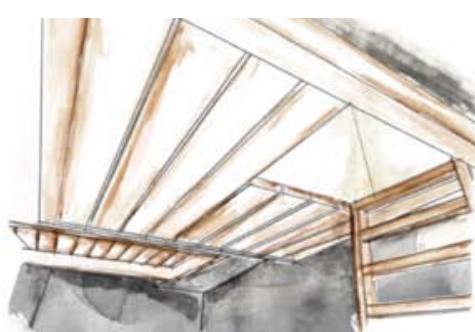

skyward view from bottom floo
Figure 9.24: Thumbnail perspectives

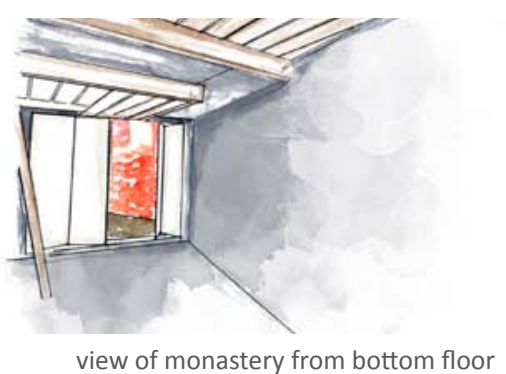

view of monastery from bottom floor
Figure 9.2: Floor plans 


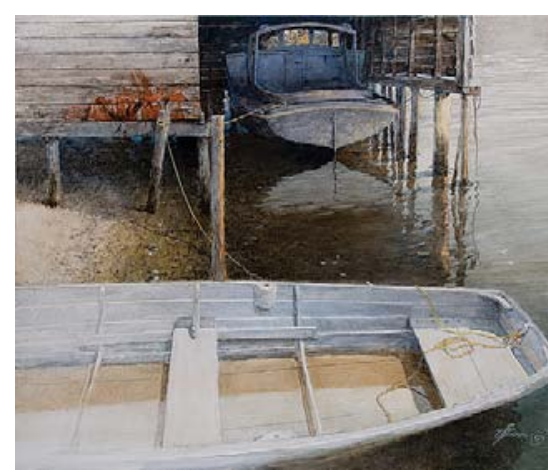

Figure 9.21: 'Classic'

\section{David Barker}

David Barker was born in 1941 in Chichester, England. His family immigrated to New Zealand ten years later. He is known as "one of New Zealand's most internationally active artists", having held exhibitions in over eighteen countries and currently dividing his time in New Zealand, Canada and the canals of Venice (Johnstone 16; Barker, "David Barker Biography"). Barker describes his work as hyper realist, however, others have noted the expressive qualities his work also contain (Barker, David Barker: The Man and His Art; Campbell). His interest in the optical illusions of water has been an enduring theme in his work. Barker has extensively experimented with light as it reflects and refracts off the surface of water. He describes the illusions of water as far beyond his own ability to create (Barker, David Barker: The Man and His Art).

A high horizon line appears in the majority of David Barker's work, a technique which ensures the focus on the highly detailed foreground where Barker places the importance on. Barker investigates ordinary objects from different angles and view points, in an attempt to understand in full the object through its interaction with light (Campbell).

In many of his later works, his interest in expressions of light moved from water to views through windows and door frames. The cracked and dusty glass panes of old and derelict buildings provides a similar illusion to water, as light bounces back and passes through the transparent surface. The structure and composition of these frames divide the different elements within the paintings as light patterns on the glass blurs the boundaries between inside and out (Campbell).

\section{Translation}

\begin{tabular}{|c|c|c|}
\hline Categories & Barker's techniques & Translation \\
\hline Light & $\begin{array}{l}\text { Through water, reflections, } \\
\text { refractions, concealing and } \\
\text { revealing depth. Through glass } \\
\text { windows. Confuses boundaries }\end{array}$ & $\begin{array}{l}\text { Window position, size, } \\
\text { lighting }\end{array}$ \\
\hline Colour & Contrasting & $\begin{array}{l}\text { Interior colouring and } \\
\text { materials }\end{array}$ \\
\hline Form & $\begin{array}{l}\text { Tension between realistic and } \\
\text { detailed to expressive }\end{array}$ & $\begin{array}{l}\text { Design of internal space, } \\
\text { materials }\end{array}$ \\
\hline Composition & \begin{tabular}{|l} 
Fabricating landscapes, high \\
horizon lines, windows/doors/ \\
built structure used as grid \\
(diving and uniting)
\end{tabular} & $\begin{array}{l}\text { View focus, window } \\
\text { detail, design of } \\
\text { surrounding space }\end{array}$ \\
\hline Themes & $\begin{array}{l}\text { Light on/through water, ordinary } \\
\text { into extraordinary, absence }\end{array}$ & $\begin{array}{l}\text { View focus, design/ } \\
\text { atmosphere of space }\end{array}$ \\
\hline Style & & $\begin{array}{l}\text { Window size and } \\
\text { proportion, view focus }\end{array}$ \\
\hline Content & $\begin{array}{l}\text { Landscapes, water areas - } \\
\text { sea, rivers, beaches, coastal } \\
\text { buildings, boats }\end{array}$ & $\begin{array}{l}\text { View focus, window } \\
\text { position }\end{array}$ \\
\hline $\begin{array}{l}\text { Human } \\
\text { element }\end{array}$ & No people, or other 'distractions' & $\begin{array}{l}\text { View focus, window } \\
\text { placement, spatial } \\
\text { programme }\end{array}$ \\
\hline Viewpoints & $\begin{array}{l}\text { Original/ interesting viewpoints, } \\
\text { often low to the ground, large } \\
\text { amount of detail at micro scale, } \\
\text { ambiguous }\end{array}$ & $\begin{array}{l}\text { Window placement } \\
\text { and size, design of } \\
\text { surrounding space }\end{array}$ \\
\hline Atmosphere & Abandonment and melancholy & $\begin{array}{l}\text { Colouring, materials and } \\
\text { spatial design }\end{array}$ \\
\hline
\end{tabular}

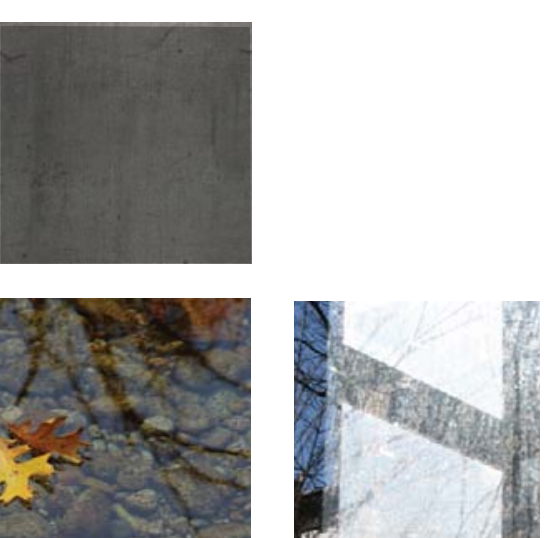

Figure 9.22: Material study

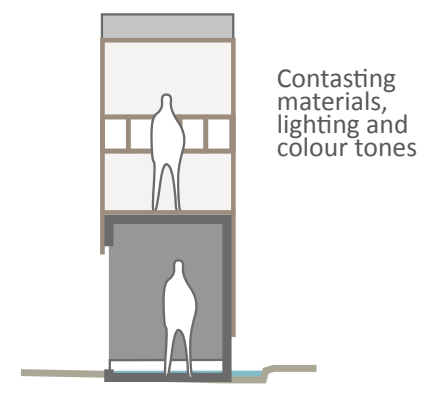

Figure 9.23: Development section sketch

Figure 9.24: Development site plan sketch

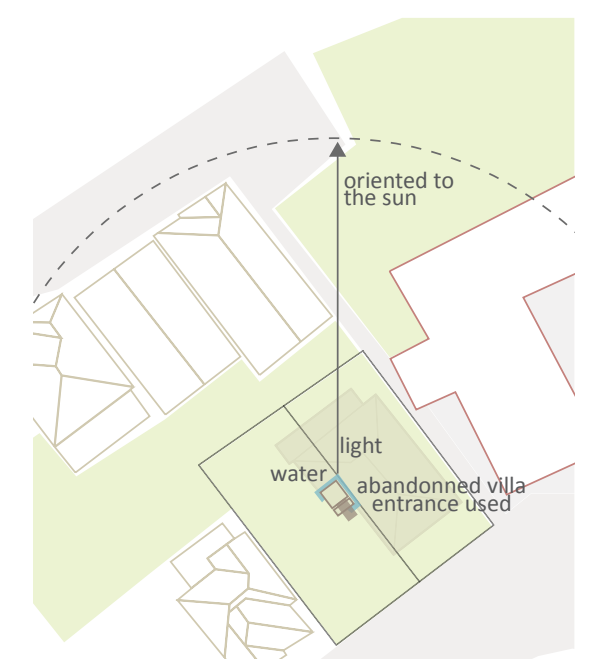




\section{Implementation}

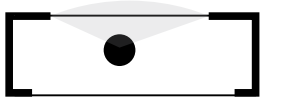

split focus

multiple view points

detailed

proximity

Figure 9.25: David Barker the outset, the range of architectural possibilities for David Barker's explorations of light through glass and water appear xtreme. However, through engaging with some of Barker's other techniques, such as, the close-up and detailed nature of much of his art and his high horizon line, a space began to unfold which closely reflects his themes and bias.

For a location on site, the only element required was a strong level of light. Therefore, the studio was placed on the southern side - well removed from the shadow of the monastery.

Considerable experimentation was conducted to distinguish between different illusions of light through glass and water to ensure the focus moves between the two elements as an artist moves through the space.

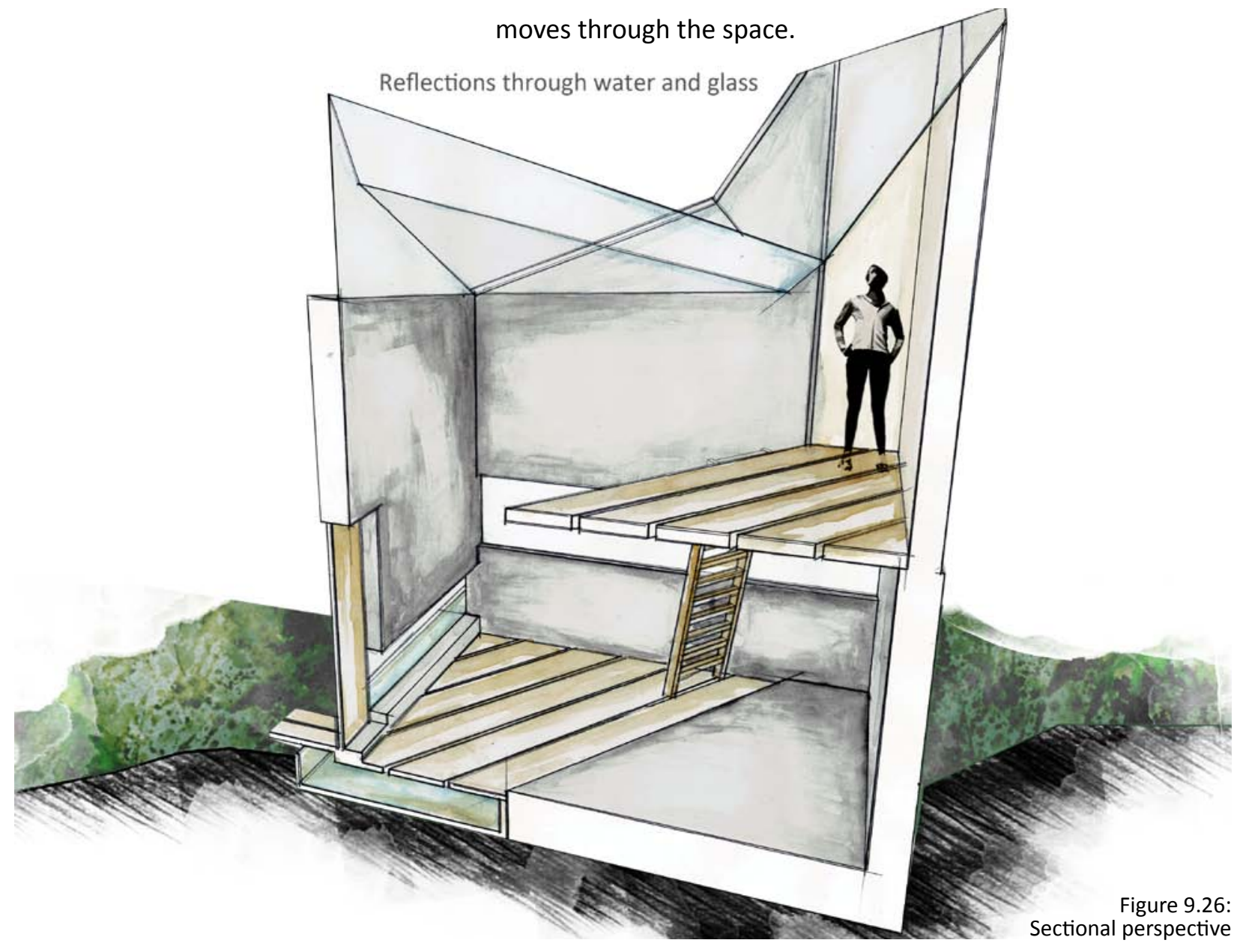

The ceiling is composed of a series of glass panes slicing along a diagonal as it funnels rain water to the north corner of the building. The water drops to a timber gutter positioned close to the ground on the north-east side. From the inside, a long window captures a low angled view of the water as light bounces off it and into the building. As the gutter fills up, it overflows to a ground level gutter on the north-west side, where a similar window opens the interior up to the continued movement of the water. This gutter releases water under half of the studio floor, with wide gaps in the floorboards offering glimpses of the watery surface.

A mezzanine level allows the artist to see above and beyond the interior of the space, offering views of the harbour and city. However, the cut of the glass funnelled ceiling bounces incoming light at odd angles. As the artist looks through multiple panes, the view is interrupted with reflections and refractions of light.

Thick concrete walls wrap around the north of the building but break away as they reach the mezzanine level. This raised platform places the artist within the display of light as it bounces around the top of the space, while the lower half of the studio remains in relative darkness, punctuated by light entering the low horizontal windows and the watery ground. The threshold from concrete wall to glass in these lower windows is direct and abrupt, with the frame hidden within the depth of the wall. This transition parallels the proximity of the collected water, as seen by the artist through the window.
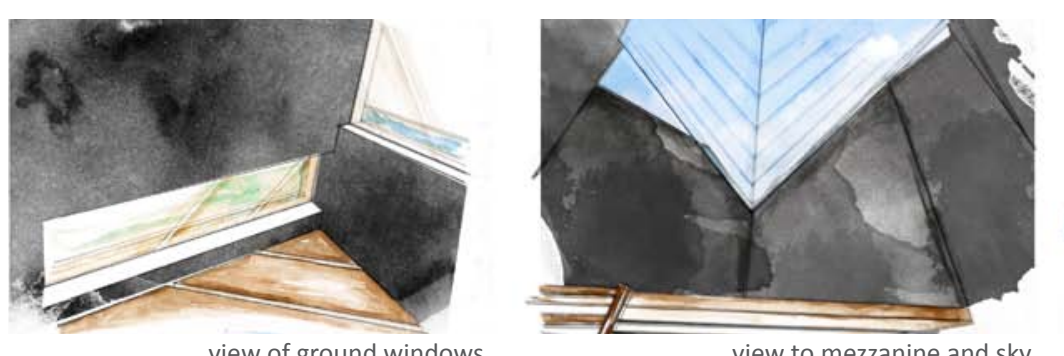

view of ground windows

view to mezzanine and sly

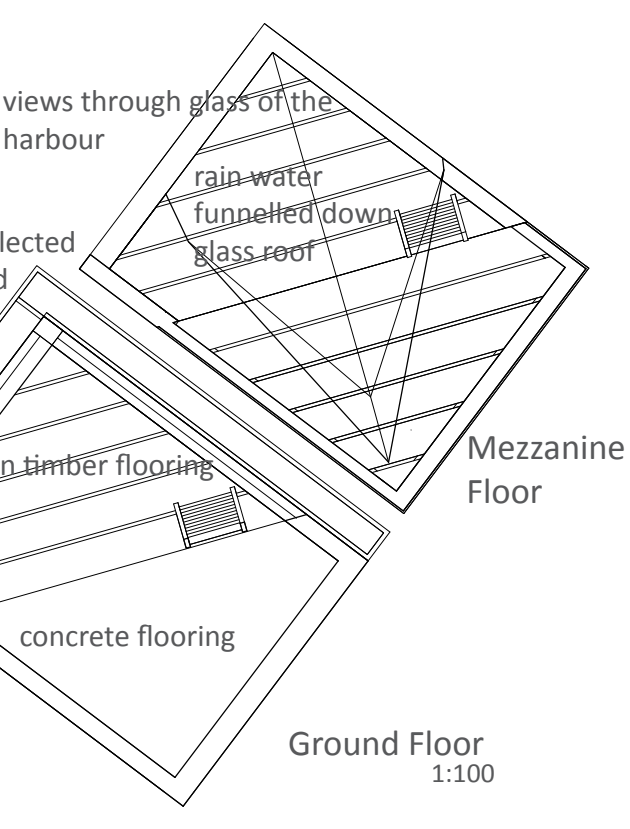

Figure 9.27: Floor Plans

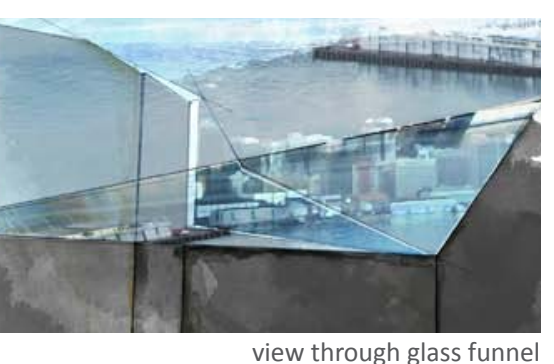




\section{Conclusion}

The outcome of these studies is a two-fold design process: one that accentuates an understanding of the relationship between a design perspective and a landscape, and one that also explores possible techniques to render this relationship. The studies offer a basic language and structure for translating a particular attitude to land into a spatial entity.

This analysis is used in the implementation of a more rigorous and comprehensive programme in the following chapter. While the above studies have a clear focus with respect to a landscape, the outcome remains at a theoretical level. Introducing the programmatic and spatial constraints of a domestic residence will test this design argument in a more realistic manner, highlighting the tensions inherent in translating attitudes towards land into architecture. 


\section{Chapter 10:}

\author{
Design part two \\ My bias
}

\author{
"Understanding landscape as scenery implies a \\ disconnection and a certain passivity between the viewer \\ and the viewed: the landscapes role is limited to what can \\ be beheld with the eye, while ours is limited to a single \\ sense, sight"
}

(Abbott, Stephenson and Ruru 13).

This chapter challenges a personal bias to glass pavilions, designed around a view. It explores the relationship between a viewer and a view, using the spatial conditions of a dwelling to reinforce attitudes towards the land. The designs are influenced by a range of research, including the history of artistic attitudes to a view, the development of technologies related to windows, the psychology of vision, and a study of New Zealand artists and their treatment of landscape.

A history and analysis of landscape art, as well as local case studies, indicate that feelings of observation and spectatorship are fundamental to an experience of a view. Linked to these feelings is a sense of solitude and separation. A view by definition physically alienates a viewer from their surroundings yet through the visual threshold of a window western society seeks a connection to this other, visual world. The first proposed design recognises these tensions. It examines ways in which a viewer engages with a viewed landscape while at the same time 
remaining removed from it.

This chapter presents a design of two houses with opposing themes. The first house, as a culmination of this thesis, will examine notions of spectatorship, separation and isolation through a form of disconnection between the dwelling and its nearby surroundings. The house is largely devoid of any interaction with its site because it is focused on an extensive, distant landscape. While this house has been designed to be inhabitable, the design highlights the limitations of a relationship with land expressed solely through a view. The spatial conditions of the house express the inability to physically connect to the land and the sense of isolation that accompanies this attitude.

The second house, displays the opposite expression, the creation of a viewed landscape which promotes accessibility and assimilation. A dwelling of a more inward nature, this design expresses the possibilities of proximity in a view, as well as a more successful transition between the visual and physical boundaries of inside and out. Similar to a courtyard house, it concentrates on drawing out external interests that lie within the boundaries of the site.

\section{Programme and site}

The suburb of Mount Victoria offers a variety of housing. The last New Zealand census notes that this inner-city suburb has fewer one family households than the rest of the Wellington region (at fifty percent compared with sixty-seven percent of households for the region as a whole), meaning that it hosts more joint living flats, giving it a younger overall population. Households in Mount Victoria that are single family households are more likely to be single member households - suggestive of professional people who live alone, given the cost of houses in the area (Statistics New Zealand).
Due to the local demographic and the extended width of the site, the design brief is two, two-bedroom houses of simila footprint and programme, suited to the conditions of the site.

A boundary was drawn down the middle of the site with House One, a house of observation, placed on the southern side of the site. Although both sides offer a similar outlook, this layout accommodates the inward nature of House Two. The intention to create a disinterest beyond the immediate site means the house can be located close to the dominating edifice of St Gerard's Church and Monastery.

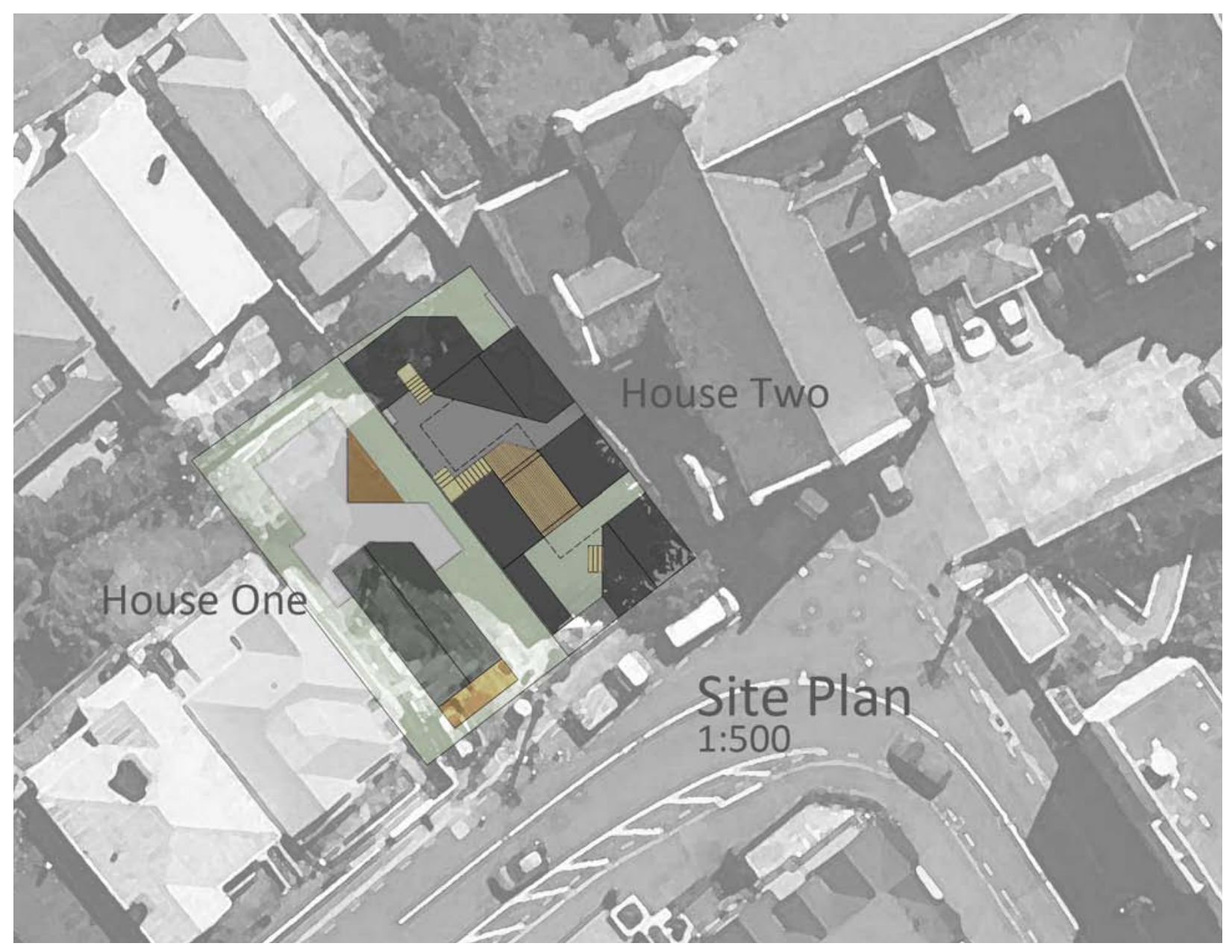

Figure 10.1: Site Plan 


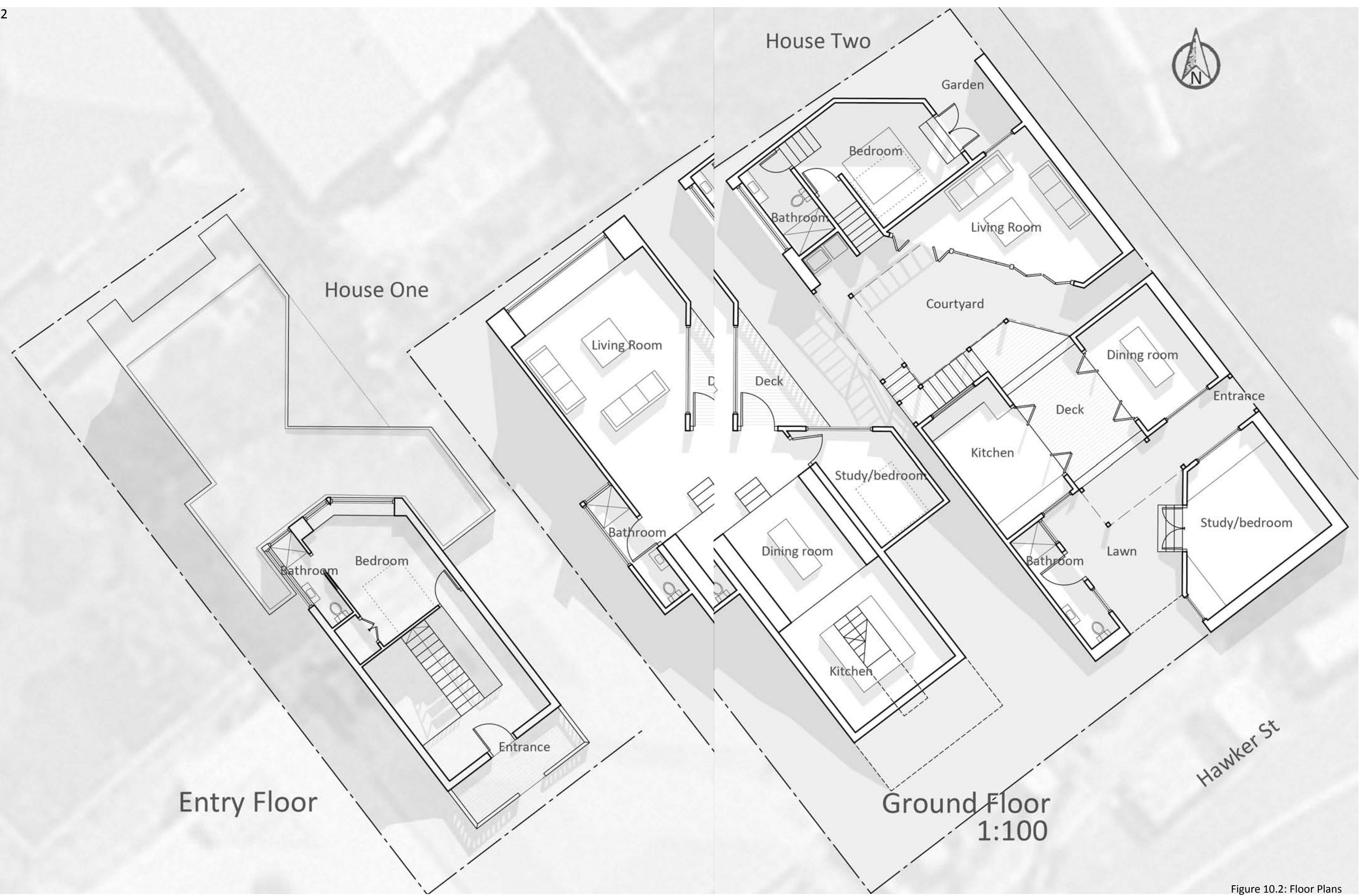


Figure 10.3: Views through interior spaces

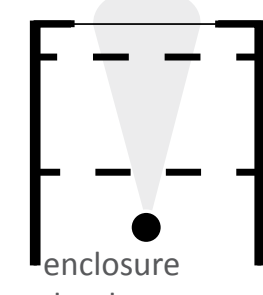
depth internal focus obstruction

Figure 10.4: Single focus

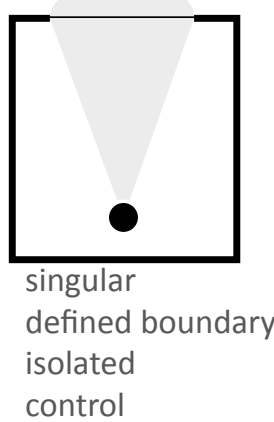

${ }^{21}$ Referred to in the definition given by the Oxford Dictionary in the introduction of this thesis, as well as discussions of one point perspective in renaissance and picturesque art, this notion of one direct view appears closely related to a historical understanding of a view.

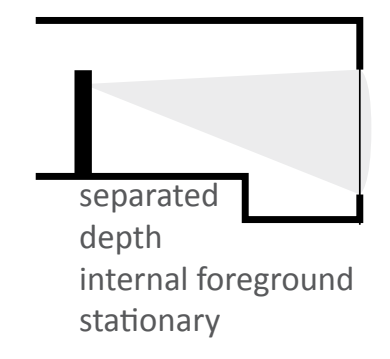

stationary

Figure 10.5: Level changes

\section{House One}

An outward focused view

House One, as a house of outward focus expresses notions of observation through the following design principles:

\section{Views through interior spaces}

Similar to of Adolf Loos's use of an interior in the Moller House, a sequence of connecting spaces has been created in this design. By highlighting the presence of the interior, a sense of separation from the outside is expressed. Along the length of the house, the view is ever-present but as a backdrop to the internal living arrangements within the spaces.

\section{Single focus}

Along the length of the house, there is a direct line of focus to one all-encompassing city and harbour view. While the view is concealed at the entrance, this directive focus exists in the presentation of a staircase immediately in front of the entry door, descending down to the living areas of the house. This singular vantage point derives from research discussed earlier, which indicates a historical preference for a simple one point of perspective in a view ${ }^{21}$. As demonstrated in research conducted in Wellington as part of this thesis, a single outlook to an extensive view is seen in many New Zealand houses, for example, 58 Ponsonby Road, and in the manner in which the architect of 731 Marine Drive discusses his view as one large prospect.

\section{Level changes}

The changes in level throughout the house reinforce the sense of separation. Removed from the house's entrance, the downstairs living spaces render an occupant devoid of the physical or visual connection to the immediate site. The subsequent floor changes in these spaces act as a form of barrier, separating the living area with its large window view from other spaces. The change in level between the dining room and living room is not large, allowing three stairs to be concealed from view until the edge of this threshold. This concealment suggests a physical inaccessibility, isolating the living room from the rest of the house.

\section{Elongating thresholds}

An elongation of the thresholds of the house achieves similar effects as a change in level. The most extreme extension is in the creation of a dining area within the space between the kitchen and living room. Acting as an internal frame, this space slows an occupant down, the reversal of movement traditionally experienced in a threshold. The other main example of this is the window at the end of the house. The threshold between the external landscape and interior has been extended into a window seat. While the threshold's depth reinforces this sense of separation, it is the manner in which a person is intended to sit away from the view that most generates this sense of isolation.

\section{Slowing down movement}

Due to the stationary stance required when observing a view, the design of this house endeavours to slow an occupant down as they follow the direct path to the view. This is achieved through the placement of furniture, floor leve changes and elongation of thresholds. As an occupant slows to the approach of each obstacle, the eyes of the occupan are drawn to the view.

\section{Filtering edges}

While the house has a very linear focus, the complexities of the programme require spaces off to both sides of this centra axis. Three secondary spaces act as filters to the view. These spaces obstruct the views beyond, similar to the technique of

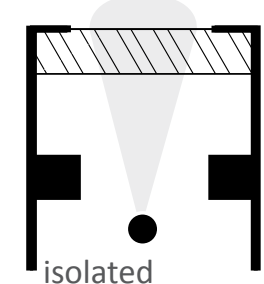
stationary
obstructed frame

Figure 10.6: Elongating thresholds

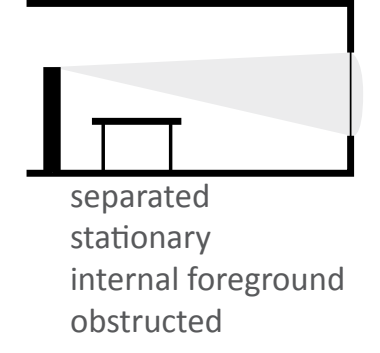

Figure 10.7: Slowing down movement

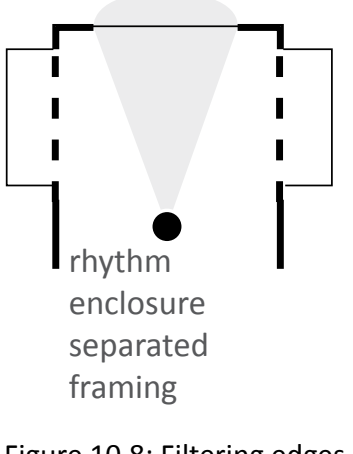


'viewing through rooms'. A bathroom and second bedroom/ office sit either side of the threshold to the living room. They offer secondary views to either side of the site, only visible at this part of the house. A sense of separation is heightened in the drop in floor level between these secondary spaces and the main spaces as well as the narrow, sealable doorway into the spaces. A north facing deck next to the bedroom reiterates this isolation through its elevated position from the site.

Figure 10.9: Alternate staircase structure

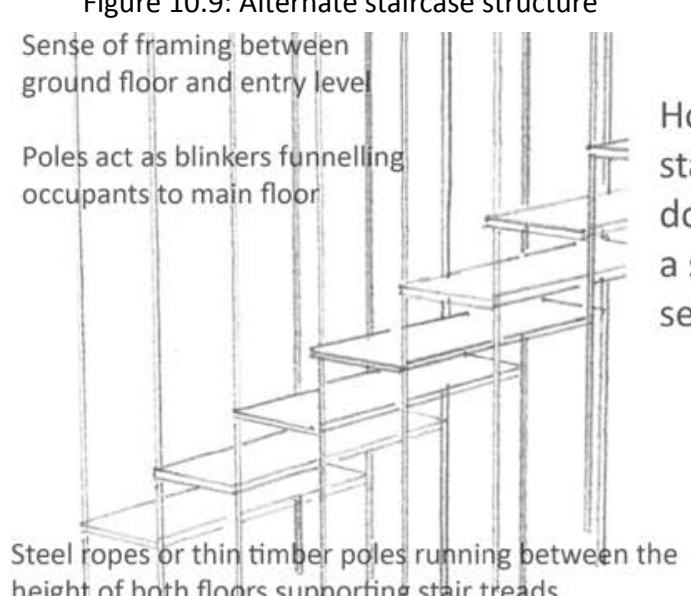
Steel ropes or thin timber poles rupning gets
height of both floors supporting stair treagds

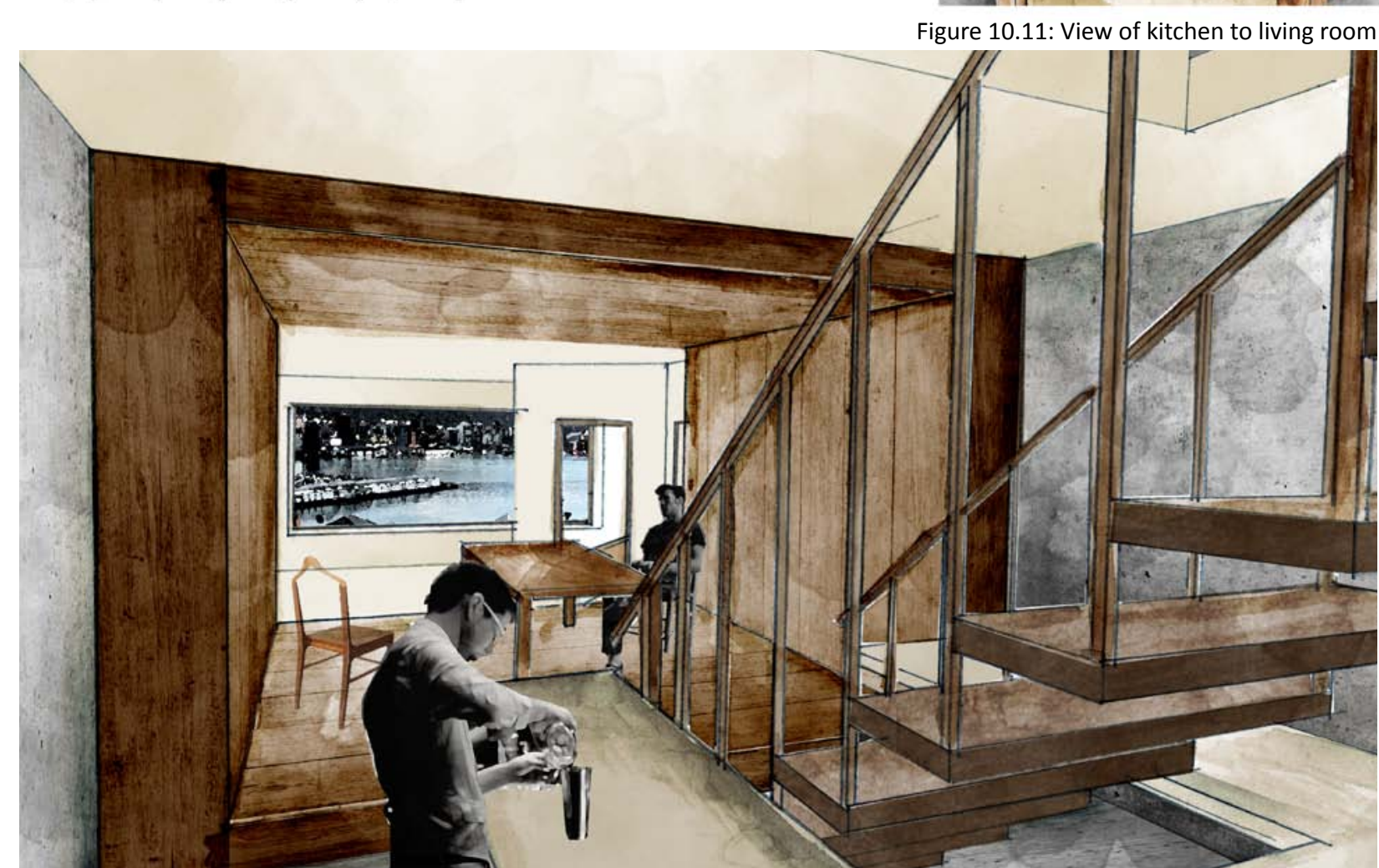

Figure 10.12: Alternate window height

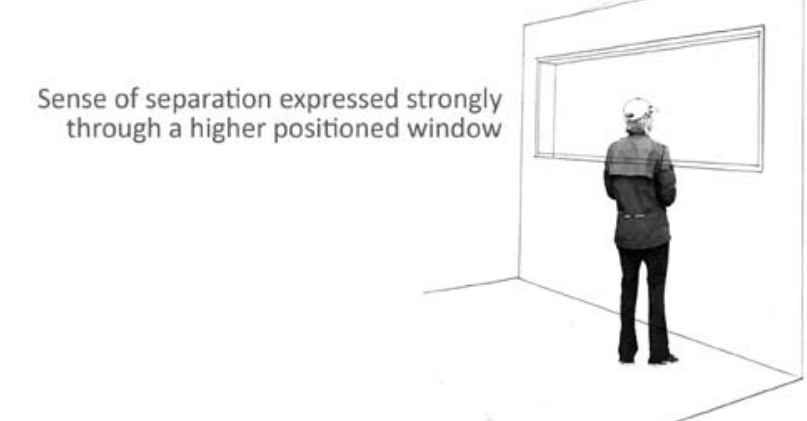

Figure 10.13: Window details

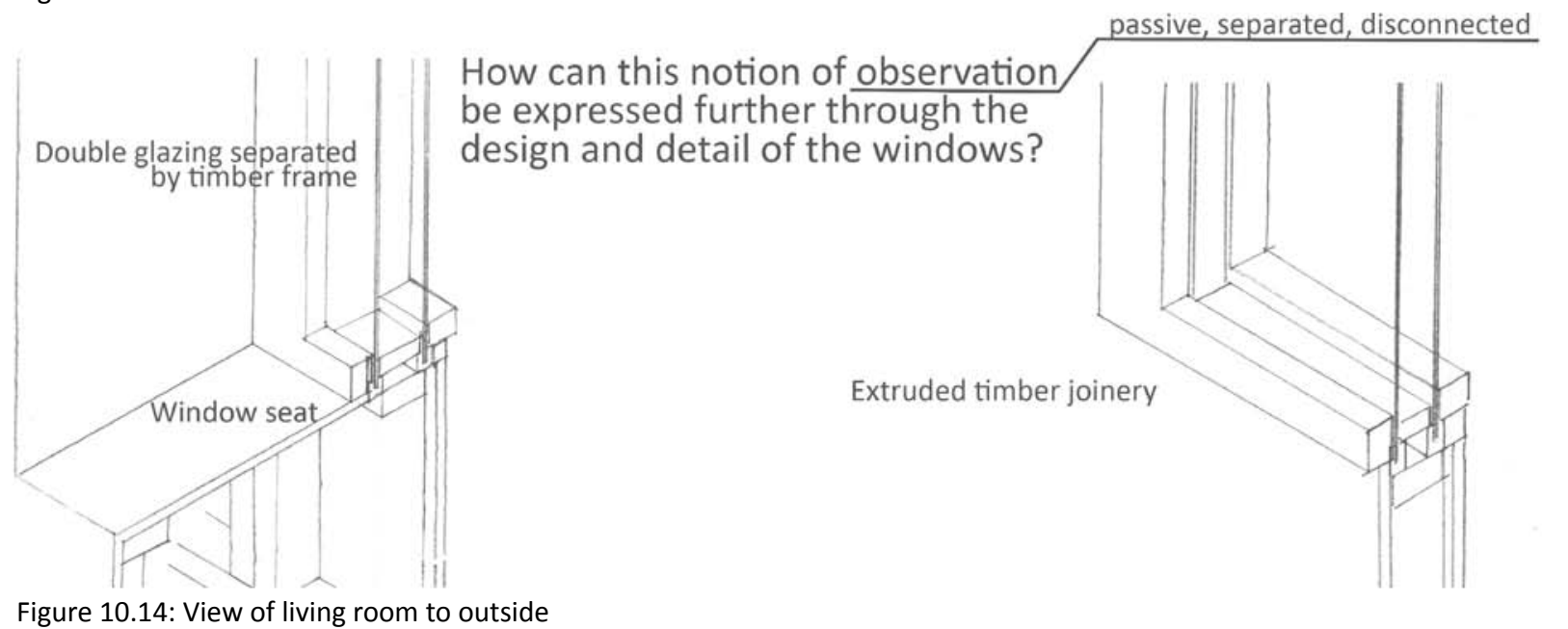

Figure 10.14: View of living room to outside

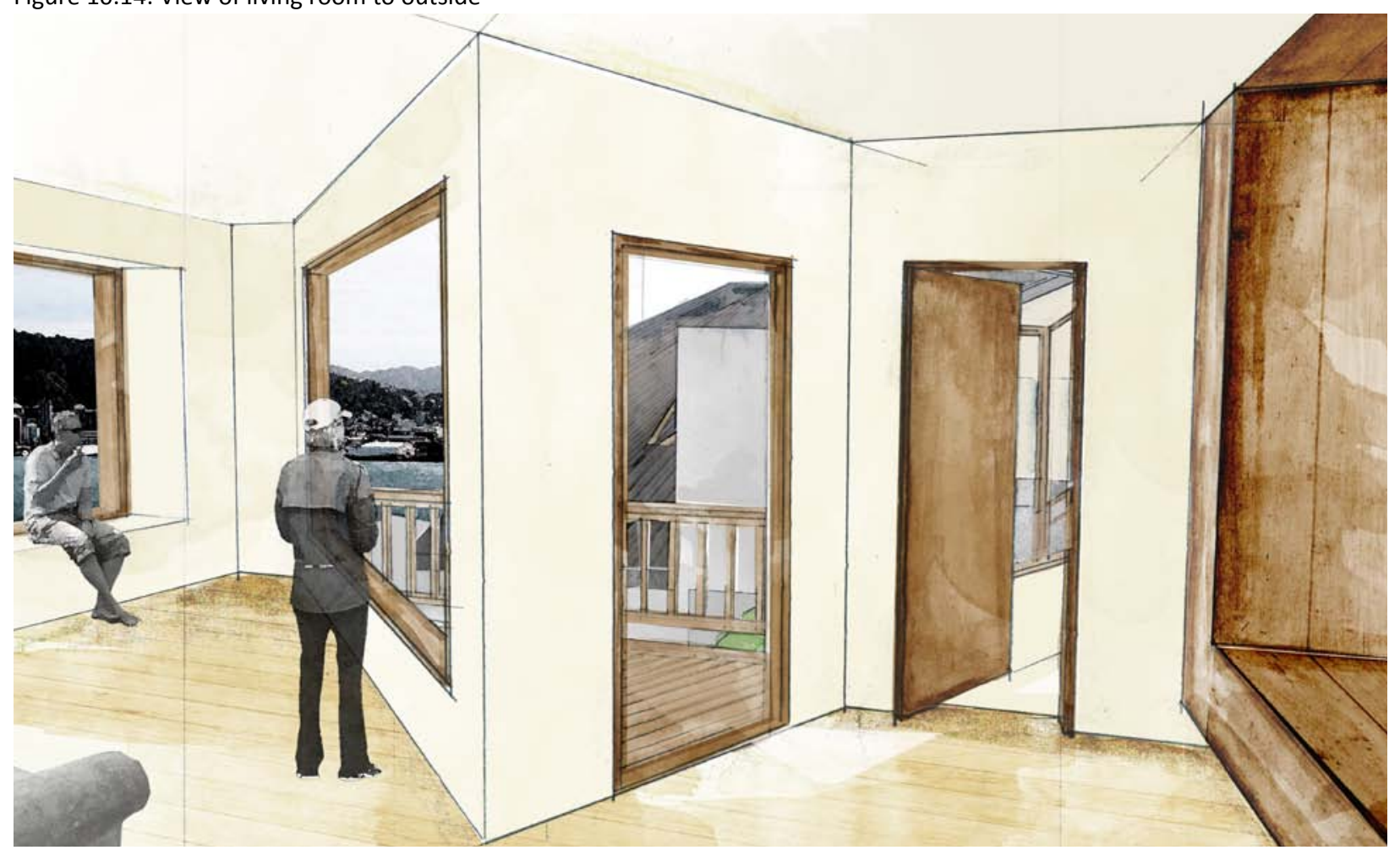




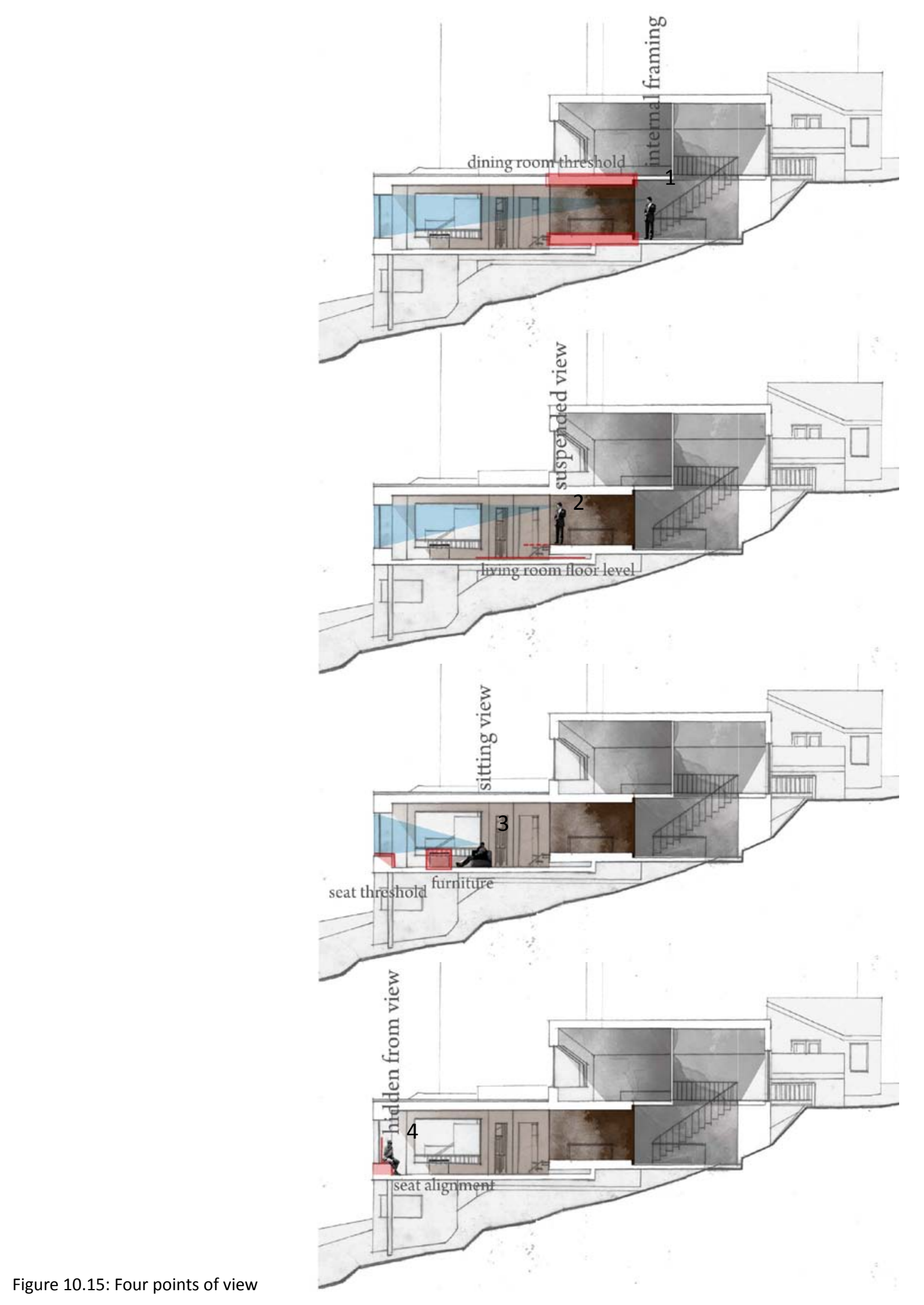

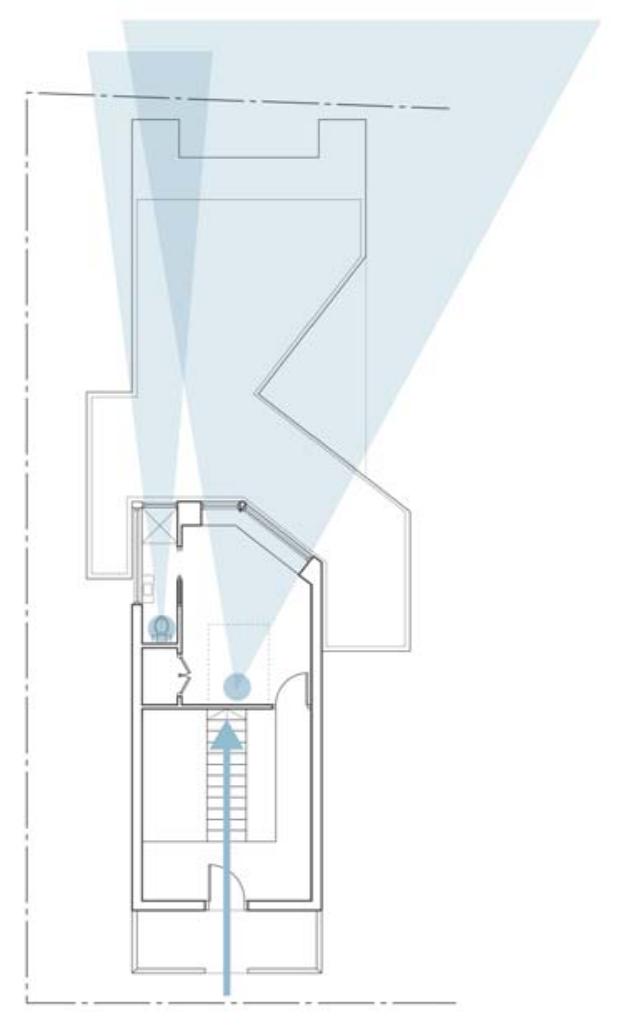

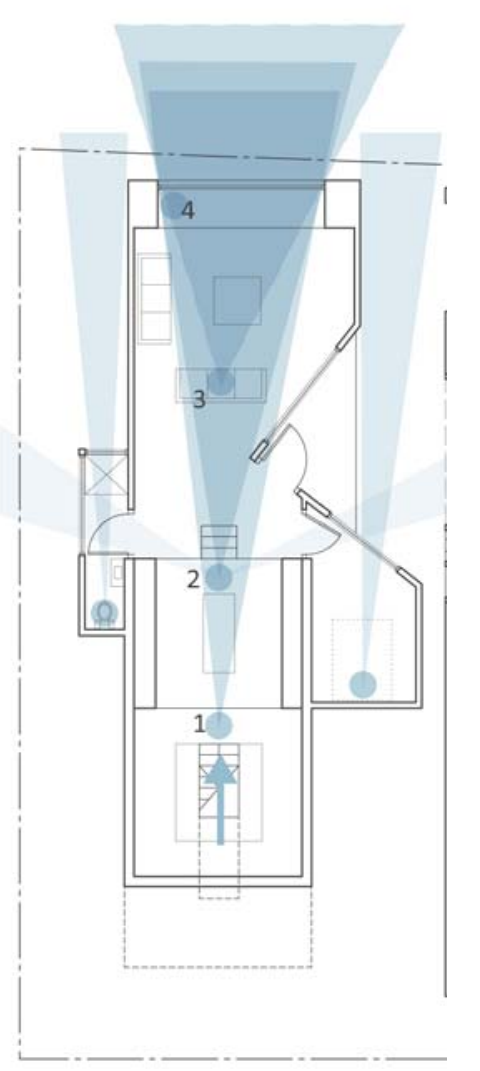

Figure 10.16: Stationary points of view
Figures 10.15 and 10.16 examine view positions throughout House One. These are moments of inactivity, when an occupant might observe the view beyond. Four key positions in the main living areas of the house have been dissected in figure 10.15. This diagram aims to highlight the manner in which the surrounding spatial conditions express the house's themes of separation and spectatorship.

Four different strategies are drawn out, following on from the six principles discussed on pages 94-96. The first is an internal frame, which separates an occupant from the view beyond. The second is a suspended view - a lowered floor level disconnecting a viewer. Thirdly, the couch's position in the living room creates a sitting view, the table and window seat obstructing the view. Finally, the window seat angles an occupant away from the view, separating them from the immediacy of the outside world

Figure 10.16 also notes other main viewing areas throughout the house. 


\section{House Two}

An inward focused view

House Two as an inwardly focused design, can also be seen as a critique of House One. The key design principles are as follows:

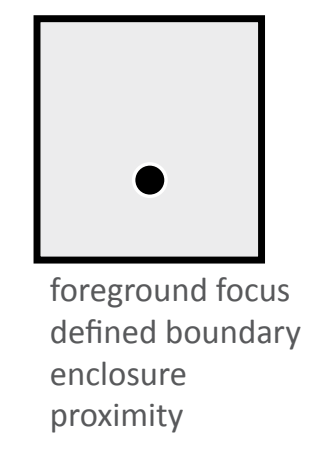

Figure 10.17: Site influence

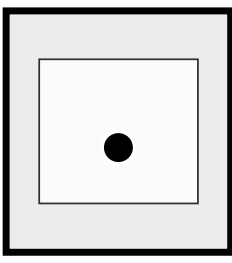

blurred

engaging

openness

proximity

Figure 10.18: Inward focus

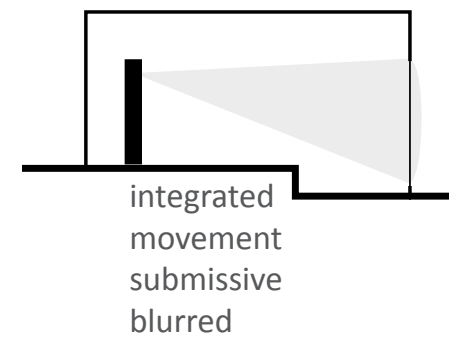

Figure 10.19: Grounded on site

\section{Site influence}

The site in essence becomes the landscape in this house. Unlike that of House One, where the landscape is the physical environment beyond the site, the site of House Two provides the setting for its external views and interest. This creates views in close proximity and a house that follows the physical characteristics of the site.

\section{Inward focus}

As noted above, the focus in this house remains within the boundary of the site. It faces away from the street and neighbouring buildings which, reduces any externa distraction. The entrance is off an existing pedestrian walkway, alongside the monastery and difficult to distinguish from Hawker Street, camouflaging the transition from inside to outside. Thick concrete walls wrap around the exterior of the house, as the rest of the internal spaces open up onto three main outside areas. While the interior views are solely on these outdoor spaces, due to the sloped nature of the site, a view to the harbour and city beyond is visible once outside.

\section{Grounded on site}

The house follows the existing contours of the site down the slope. This direct connection to site is important as it allows for easy movement in and out of the spaces' thresholds. In contrast to House One, this house is grounded in its site. At the bottom of the site, the ensuite bathroom presents a view underneath the neighbouring house, reinforcing the close relationship to the land.

\section{Encouragement of movement}

The physical connection to site creates a continual change in floor level throughout the spaces in the house. This in turn generates a sense of movement throughout the house. This movement is encouraged as occupants weave around the outer edges of the site. Instead of passively observin the landscape, this house promotes a sense of exploration through internal and external spaces on site.

\section{Multiple points of view}

The placement of the internal spaces around the periphery of the site generates multiple points of view into the three areas of focus. The continual changes in levels and orientation create a variety of changing perspectives for occupants of the constructed landscapes. These viewpoints, similar to techniques in modern art, offer more information about the site than one direct view. They highlight the level of interaction an occupant has with the site within the house.

\section{Blurring thresholds}

The multiple thresholds inside and outside this house are blurred through the continuation of surface material, texture and floor level. This ambiguity between the interior spaces and the outside spaces encourages movement and unity between house and site. The house's windows and doors direct the focus into the outside spaces, visually through the thin structure of these elements and physically through the ability of these elements to open and fold away.

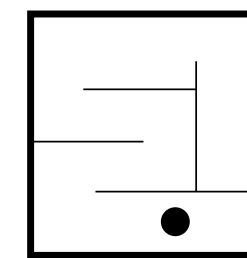

control

interactive

blurred

fracture

Figure 10.20: Encouragement of

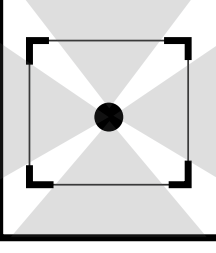

varied

exposed

divided focus

openness

Figure 10.21: Multiple points of view

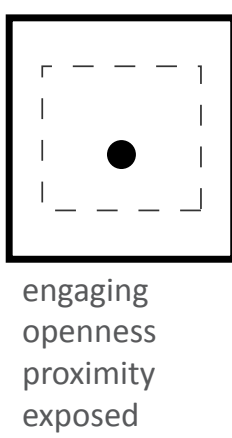

Figure 10.22: Blurring thresholds 

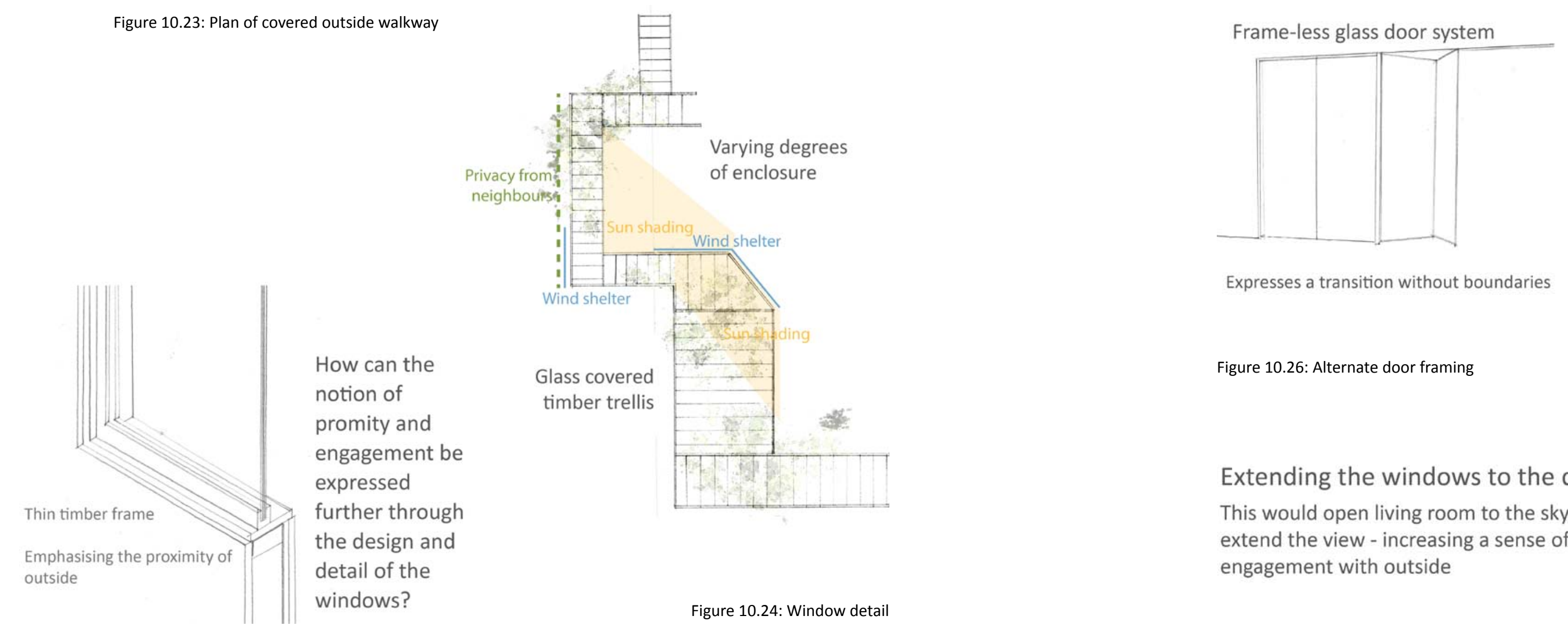

Figure 10.24: Window detail

Figure 10.25: View of front lawn and deck

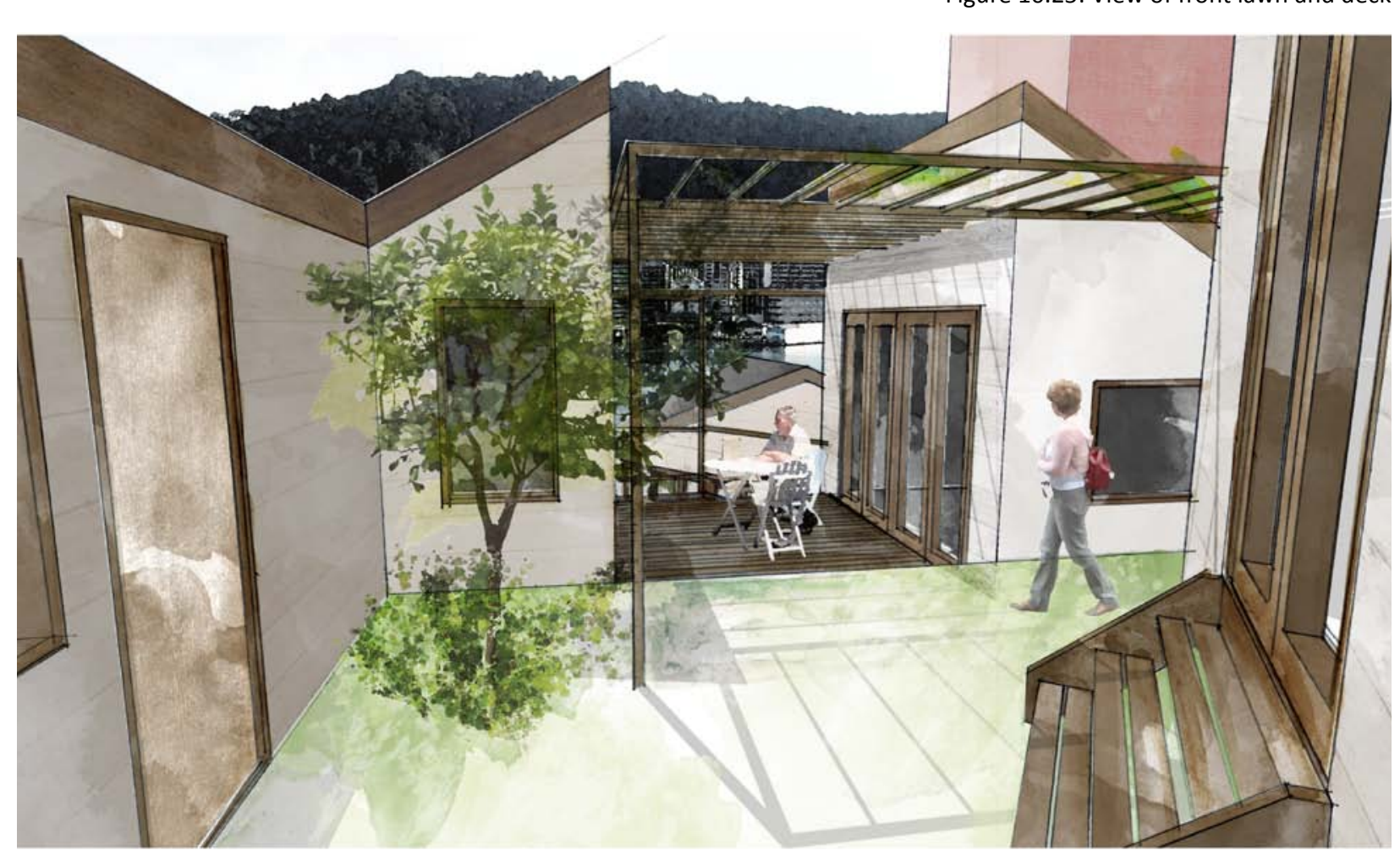

Figure 10.26: Alternate door framing

Extending the windows to the ceiling?

Figure 10.27: View of living room and courtyard
Thin timber framed door system

A question of framing?

Expresses a transition without boundaries

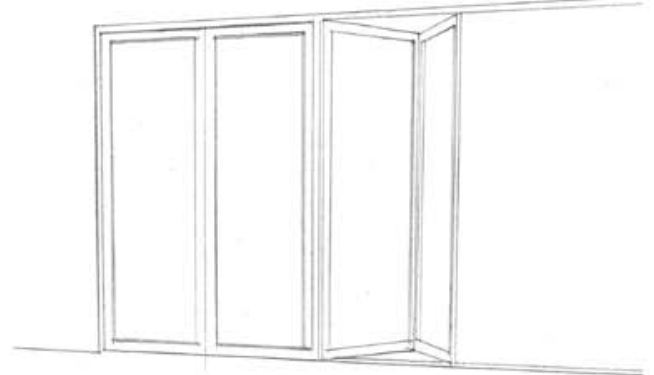

Increases a sense of proximity to outside yet retains a distinction within boundary

This would open living room to the sky, and However, current window has a strong focus extend the view - increasing a sense of on a view to the courtyard only. It invites engagement with outside occupants outside while retaining a defined area of focus

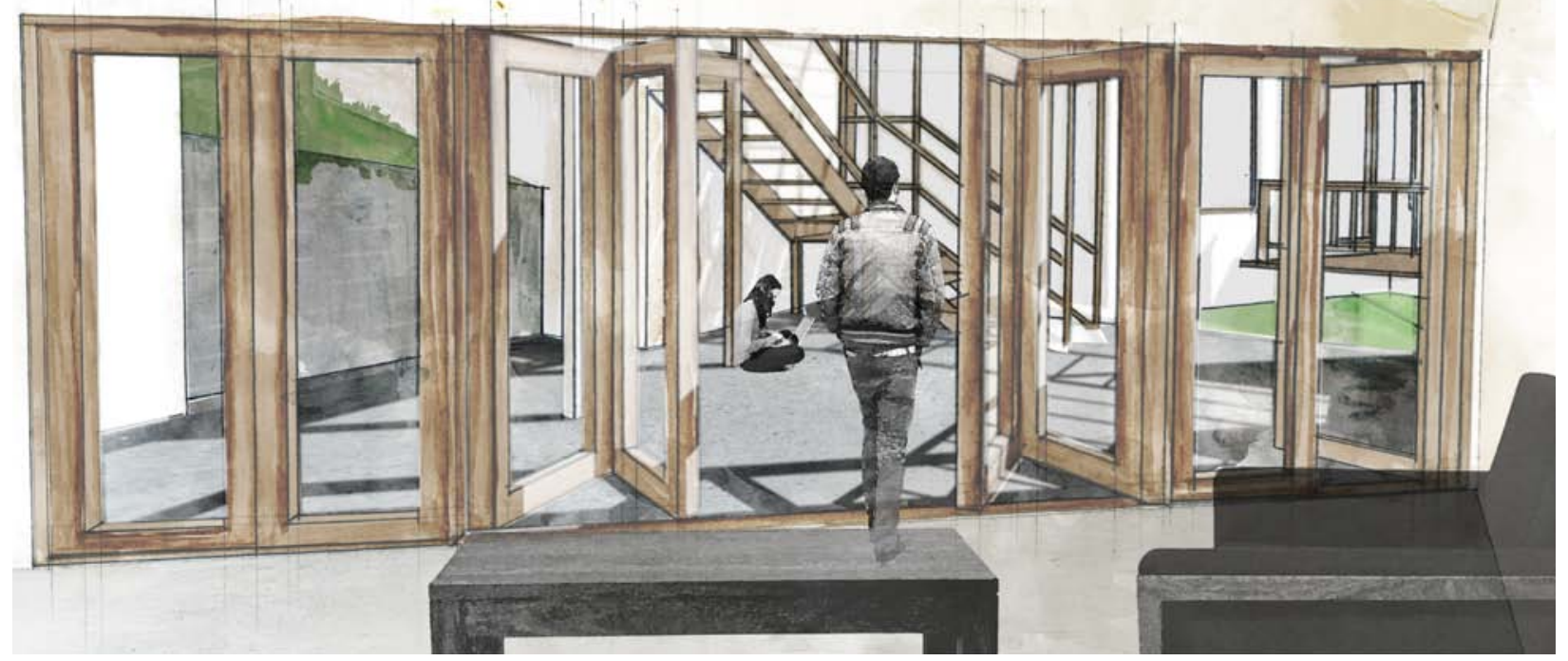


Figure 10.28 examines the common paths of movement throughout the site of House Two. It illustrates three entrances along the northern boundary, while the rest of the movement is contained within the property. This diagram highlights the

hierarchy of movement in and site are explored and

Figure 10.28: Movement paths

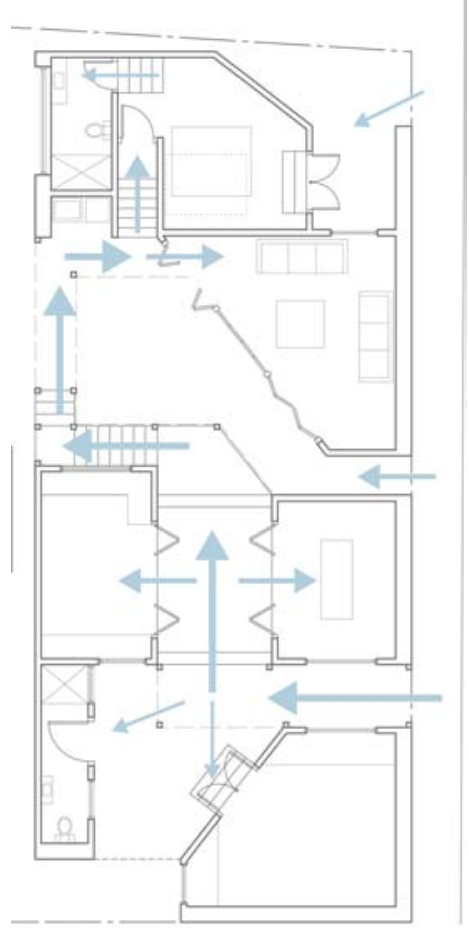

Figure 10.29 examines the varying levels of enclosure through the site of House Two. It depicts the highest levels of enclosure around the periphery of the site, within thick concrete walls. This diagram also highlights the gradual change in level throughout the site, often unrelated to the house's external thresholds.

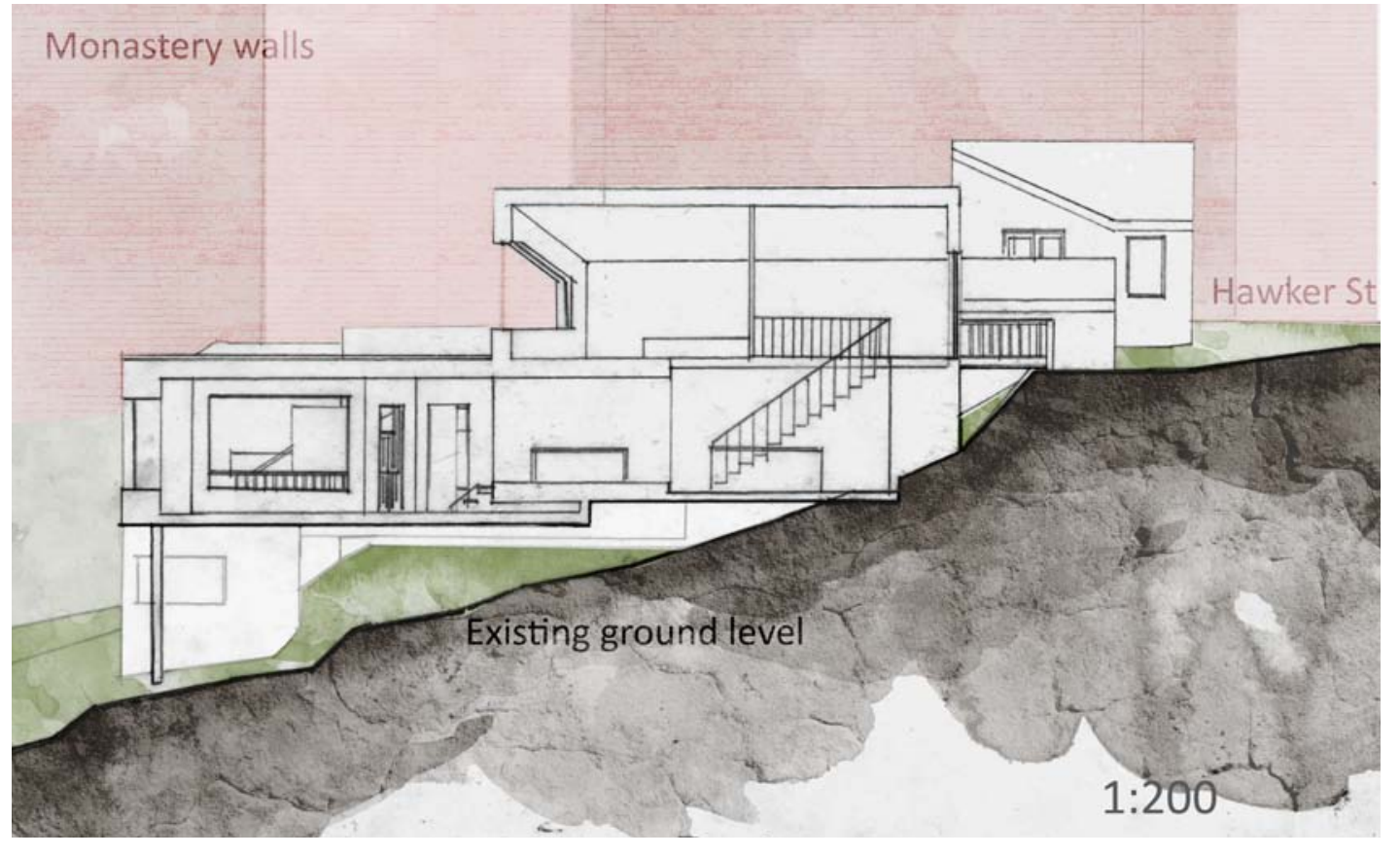

Figure 10.30 Section through House On

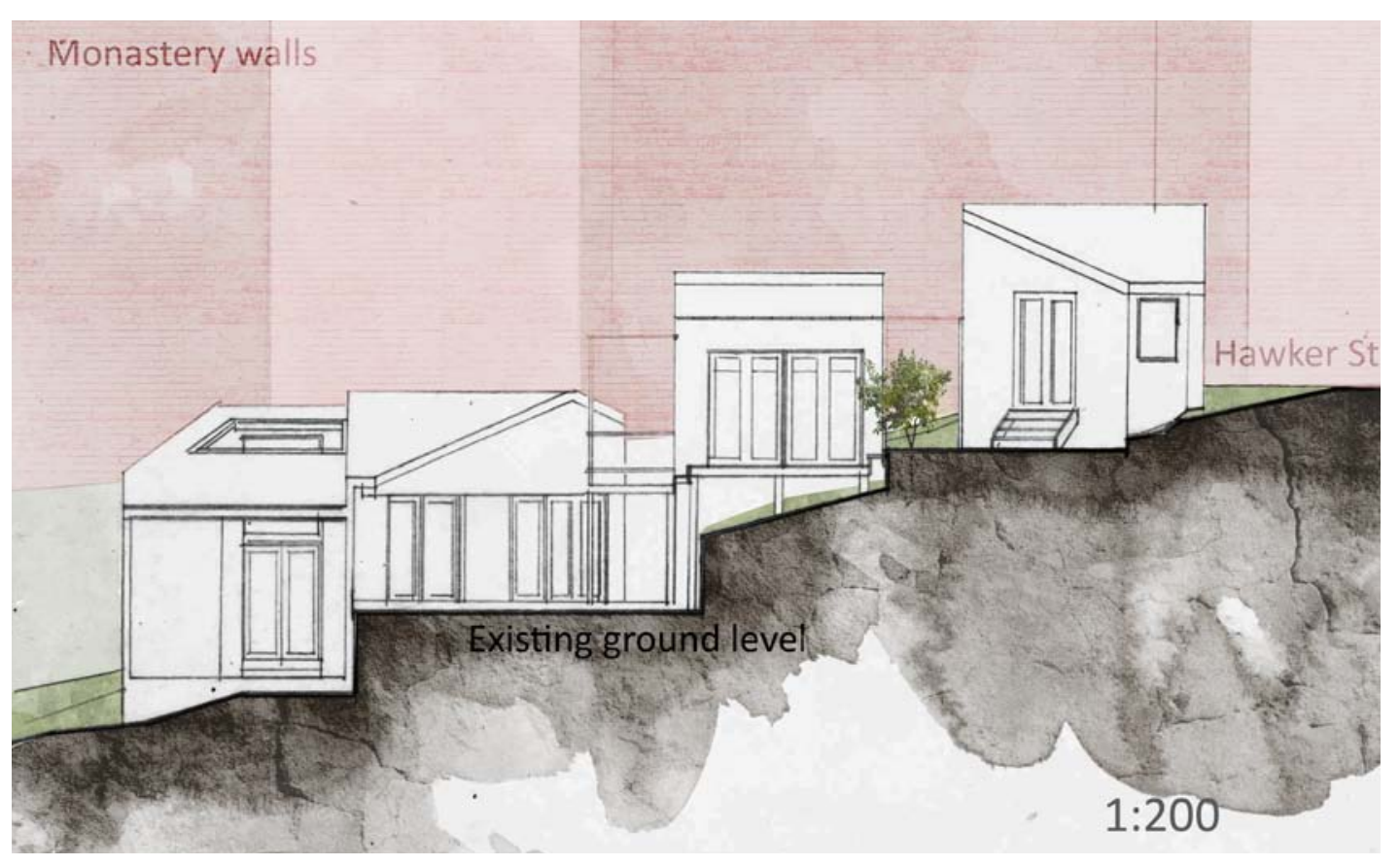

Figure 10.31: Section through House Two 


\section{Conclusion}

Through the plans, sections and perspectives, as well as the above text, this section endeavours to create two houses, expressing two opposing relationships to landscape through their architecture. The organisation of spaces, materials and detailing has rendered two very different houses. By retaining a parallel programme and footprint, these houses offer a clear comparison of relationships to the land they occupy and the landscapes they overlook.

The studio spaces of the first part of the design process have left clear impressions on the final designs. The houses may lack the simplicity and clarity of the studio spaces but they retain many of their influences, especially in the way they relate to their immediate site and evoke a connection with the wider landscape. Both exercises have highlighted the value of a dedicated design concept to bring a sense of wholeness and integrity into a plan. The following chapter will reflect on the execution of the designs as well as other aspects of the research process. 


\section{Chapter 11:}

\author{
Reflections and conclusions
}

This chapter presents final reflections and conclusions of the design-research process and outcomes. By tying together the various approaches to research, it offers a summary of findings on architectural considerations in respect to views of New Zealand landscapes.

\section{Research scope and summary}

The aim of this study has been to develop an understanding of the role of a view in a domestic environment. Through achieving this aim, the scope of this thesis has been centred on the use of architecture to support a connection with landscape. More specifically this thesis has examined the potential New Zealand landscape paintings have to enrich views of landscapes, especially of nature, from New Zealand homes.

From an understanding of a selection of artistic treatments of landscape, it is evident that in western society, an appreciation of a view is based on a wider relationship with nature. This connection with landscape is influenced by cultural considerations, which from early times determined how people relate to the world around them. This relationship is not static, as demonstrated by the evolution of a view from the Ancient Greeks to present day. However, in the evolution of this relationship, certain characteristics of importance have been retained. Western society has moved from seeing nature as a force of the gods, outside a person's control, as in Classical times, to a thing of 


\section{A note on Landscape}

The notion of landscape has increased in significance as this study has progressed. The term 'landscape' defined in this thesis as a visual appearance of land has connotations of an extensive visible physical area. Land has a broader meaning, with emotive associations that are not necessarily visual. The original scope of this thesis did not explcily extend to a consideration of land or landscape but it has become apparent that a consideratio of a view and its treatment should not take place outside of this wider context. A connection to land and the attitudes of New Zealanders to landscape appears to play an important part in the expectations surrounding a view. The presence of land and landscape in the title of this thesis denotes its importance in the discussion of a view but analysis of the significance of specific landscapes is not included.

The site for Chapter nine and ten was chosen for its panorama of city, harbour an hills - aspects of a view noted as important by the research studies of Chapter thre and interviews of clients in Chapter six However, further examination into a view's content has not been performed. Similarly, techniques for accentuating view angle and elevation, distance and detail, and a singular panorama versus multiple views have not been separately examined. beauty, to be contained. Although natural landscapes are now accessed for pleasure, they are nonetheless still experienced as a distinct environment, a "natural" environment. As with a painting of a landscape, engagement is imaginative, not real.

The link to art in this thesis is considered through a series of studies on the treatment of view by four artists who painted New Zealand landscapes over the past hundred years. The process endeavoured to test whether their creative themes could assist in the development of new ways of rendering a prospect of the external world through an architectural design. The manner in which John Gully, Rita Angus, Gerda Leenards and David Barker have approached their paintings has been translated into an architectural language so that the singularity and clarity of their styles in landscape painting can influence an architectural design, in the expectation this will better support a portrayal of land and landscape.

Research into psychological attitudes (Rachel Kaplan et al.) towards natural landscapes appears to indicate that access to a view of the natural world promotes well-being, and that the opposite, no visual outlook at all, is not conducive to wellbeing. Thus, from this background research, it is considered that western society's response to a view is complex and cultural. It is closely linked to the treatment of landscape in art. There is a sense of separation in a response to a view yet, in contrast, a connection with qualities represented by a view is desired as it offers a connection to something larger or more "natural" than the constructed boundaries in many urban environments.

\section{Thesis Contention}

In accordance with the objectives of the thesis, two lines of argument have been drawn from the research and analysis. The first and primary contention of this thesis is that architecture can enhance a person's existing relationship with the landscape around them. Similar to a painting, access to a view of the outside world may present an opportunity to visually connect to external surroundings. Through the spatial conditions of a house, this connection can express a particular theme or aspect that exists in a visible landscape. This argument reflects the close connection a view has with its artistic rendering. Born from a critique of large, 'all-encompassing' window views, this argument suggests that floor to ceiling windows, while offering a panorama of visual qualities within a landscape, do not offer the intimate relationship with landscape that can occur in the media of landscape painting.

The argument is tested in the architectural translations of four New Zealand artists' work. Within the parameters of an artist's studio, a specific theme within each artist's body of work has been explored through the sphere of architecture. Through translating the techniques and motivations of an artist into a studio space's orientation, layout and use of materials, a translation of art to architecture has been explored. The result highlights the value of a selective rendering of a view used by an artist within an architectural work. Just as an artist selects aspects of view to confront through their work, so too can an architect.

A secondary argument is that an experience of view, or spectatorship, arouses specific common feelings of separation and isolation. This contention aligns with the purely pictoria way that landscape has been observed since the evolution of the picturesque style in art. It is confirmed in the attitudes of some house owners in Wellington and the analysis of landscape art 
in New Zealand. It is further reinforced in wider research cited in this thesis, such as Francis Pound's various commentaries. Chapter ten seeks to present two opposed perspectives for consideration; a house for observing nature, which relies on a feeling of separation, and a house with a closer, more integrated relationship with the surrounding land.

\section{Research aims, outcomes and future development}

The final house designs demonstrate two completely different approaches to treatment of a view, or, as noted above, treatment of a viewed landscape. The aim of these house designs is to demonstrate that a design which aims to present "a viewing platform" alone limits a relationship between a viewer and view, as well as a balance between an interior and exterior of a house.

The aim of House Two is an alliance between site and building. The design of the house offers an inhabitant a relationship with the surrounding site beyond their sense of vision, encouraging an apparent desire for active engagement with an outside environment. Paradoxically, although there is not a dominating wide view to the outside, the role of a view to the outside is possibly more important in House Two because the nature of the design reinforces a wider connection to details of site and at the same time recognizes a feeling of separation from natural elements in the wider landscape.

It is the downstairs living space in House One which has been the main focus for an exploration of the reverse - establishing notions of separation. While the entrance space plays a key role in removing the main part of the house from any physical connection to site, in retrospect, little consideration has been given to the upstairs bedroom. Throughout various iterations of this plan, a bedroom has been located upstairs to highlight a further level of interior separation and privacy. However, as the bedroom is accessed from the main entrance, not the main living areas, this effect has been lost. As a critique of House One the upstairs bedroom has yet to express the intent of the rest of the house, being primarily located for programmatic and site suitability.

While at a detailed level the two house designs specify window frame design, this thesis is more interested in the relationship between the spatial conditions of an interior and a landscape view, and as such, framing details have been given limited recognition. There is no doubt that as a part of the overall design a frame is significant, but the specific influence of differen frames has not been examined.

In fact, this thesis suggests that an experience of a view is not based simply on the content or immediate frame, but the entire environment in which a view exists. This experience is altere by the size, proportion, movement path and material palette - the architecture - of the space in which it is displayed or viewed from. The common white walls of an art gallery offer neutral setting for viewers to contemplate landscapes, yet how would a viewer's perception of these artistic expressions of land alter if they were placed in a more chaotic and comprehensive programme of a domestic dwelling? This thesis endeavours to demonstrate that if a view is to be a priority in a home, a more balanced and considered relationship between inside and out is necessary for an enhanced engagement with a landscape beyond.

A significant source of tension throughout the design process has been the steep slope of the site. This has most particularly affected House Two but has also influenced the planning of House One. While the prevalence of sloped sites in Wellington was one of the main reasons for choosing this site, this particularly sloped piece of land has affected many design decisions in 
${ }^{22}$ An initial exercise was carried out to breakdown generic spaces within a house and to catalogue their functions, duration of use, relevant furniture and qualities of view desired from each space. This table was completed based on untested assumptions. This line of argument for a more explicit link between programmatic function and a view was not pursued. However, through a more quantitative process, data collected could be valuable to help understand the nature of a view sought from different parts of the house. This exercise could also provide furthe general insight into the value of specific landscapes ways that run counter to the design argument. This would have occurred with any house design in this site and is unrelated to the specific design intentions. As a further development, it would be interesting to reconstruct a parallel design in a series of different environments and analyse the outcomes.

Another aspect of possible further development is the integration of both intentions within one house. As two houses of opposite extremes, a more practical response might be an amalgamation of the two. This third house would offer both the 'safety' of a separated landscape, as well as the ability to engage with nature. The distinction between the two could be determined by the programmatic functions of individual spaces. An exploration of specific internal functions and the appropriate view conditions could be an interesting study as the catalyst for these different approaches ${ }^{22}$.

While House Two is designed to offer a more successful holistic approach to landscape, House One offers several options for further exploration, especially the distancing and passivity of the landscape. On its own, the distant view has no connection with the house at all, but as an aspect of more coherently designed house, this element might present an interesting counterpoint. It is believed that the direct focus throughout the house offers a sense of legibility, security and strength to the design. These qualities are also expressed in the exploration of thresholds, the small changes in floor level and width within the internal spaces denotes the change in programme and function.

Further, the design of House Two has a sense of playfulness and energy in its exploration of landscape. The design pursues an insistence to move inside and out between the individual spaces. This may in reality be impractical, however, it challenges not only notions of viewing landscape but contemporary opinions on security, comfort and shelter from the external elements. This extreme example requires a complete reinterpretation of a house's connections to the outside and the attitudes of the inhabitants that reside there. In this way, House Two offers the most original design thought and better extends the possibilities of engagement with a view.

Finally, the research has suggested that attitudes to a view amongst most New Zealanders, whilst derived from a common background, are in a sense extremely personal. One house owner seeks to watch the play of light on water and another appreciates the come and go of transport around the harbour. However these interests are accommodated in a house design it is suggested that an interior of a house ought to create an expression of these interests within the design of a view rather than be a platform for which an overall view is presented. 


\section{List of figures:}

Figure 1.2: Moving viewpoint $\quad 15$

Authors own image

Figure 2.1: Window framing

Authors own image

Figure 2.2: 'Het Melkmeisje'

Vermeer, Jan. Het Melkmeisje. 1660. Rijksmuseum, Amsterdam.

Rijksmuseum, n.d. 7 July 2011.

<http://www.rijksmuseum.nl/collectie/zoeken/asset.jsp?id=SK-

A-2344\&lang=en>

Figure 2.3: 'Het Glas Wijn'

Vermeer, Jan. Het Glas Wijn. 1662. Gemäldegalerie, Berlin.

Staatliche Museen zu Berlin, n.d. 7 July 2011. <http://www.smb.museum/smb/sammlungen/details.

php?obj|D=5\&n=0\&r=0\&p=24>

Figure 2.4: Perret's vertical window

Gwinner, James. "Rue Franklin Apartments." Great buildings online. 16

June 2011.

<http://www.greatbuildings.com/cgi-bin/gbi.cgi/Rue_Franklin

Apartments.html/cid_1089832830_RueFranklinApts_Window.html>.

Figure 2.5: Le Corbusier's ribbon window

Howe, Jeffery. "Villa Savoye, Exterior." Boston: Boston College, n.d. 16 June

2011.

<http://www.bc.edu/bc_org/avp/cas/fnart/Corbu/savoye1.jpg>.

Figure 2.6: Enclosing an interior

Authors own image

Figure 2.7: Television versus a view

Authors own imase

Figure 3.1: View patterns 
Authors own image

27 Figure 3.2: Factory at Horta de Ebro

Picasso, Pablo. Factory at Horta De Ebro. 1909. Pablo Picasso.org, n.d 27 Aug 2011.

<http://www.pablopicasso.org/pablo-picasso-painting-gallery2.

jsp>.

$27 \quad$ Figure 3.3 Multiple viewpoints

Authors own image

28 Figure 3.4: Views through rooms

Authors own image

Figure 4.1: Restored Kilbirnie villas, Wellington

Wellington City Council. Restored Kilbirnie Villa. "Wellington

Case Studies - Kilbirnie Villa." Wellington: Wellington City Council, n.d. 28 Nov 2011.

$$
\text { <http://www.wellington.govt.nz/services/environment/sustain/ }
$$

case/kilbirnie.html>.

$35 \quad$ Figure 4.2 and 4.3: The Group's Robertson House

Devitt, Simon. Roberston House. 1963. "Group Architects

Exhibition." Auckland: The University of Auckland, n.d 16 Nov 2011.

<http://www.creative.auckland.ac.nz/webdav/site/nicai/shared/

about/events/2010/10/Group\%20Architects\%20Exhibition $\% 20$

Catalogue.pdf>.

37 Figure 4.4: Harcourts advertising

Harcourts. 411 Marine Drive, Mahina Bay. n.d. "Section with

Seaviews." Wellington: Harcourts, 2011. 29 June 2011.

<http://www.harcourts.co.nz/Property/View/EA3185/

Eastbourne-411-Marine-Drive-Mahina-Bay>.

40 Figure 4.5: New Zealand tourism website design

Tourism New Zealand. "Kia Ora, Welcome to New Zealand." Tourism

New Zealand, 2011.

<http://www.newzealand.com/int/>.

43 Figure 5.1: Le Corbusier's plan for La Petite Maison

Le Corbusier. Le plan est installé. n.d. Une Petite Maison,1923. By Le

Corbusier. Zurich: Editions d'Architecture, 1981. 9.

$44 \quad$ Figure 5.2: Ribbon window

Anonymous. "Corseaux-Vevey: La Petite Maison: Le Corbusier in

Svizzera." Abitare (1982): 8 ,

44 Figure 5.3: La Petite Maison

Authors own image

45 Figure 5.4: Moller House plan and section
Loos, Adolf. Moller House. n.d. "The Split Wall: Domestic

Voyeurism." By Beatriz Colomina.. Sexuality \& Space Ed. Colomina, Beatriz.

New York: Princeton Architectural Press, 1992. 79.

Figure 5.5: Threshold between dining and music room

Moller House. n.d. "The Split Wall: Domestic Voyeurism." By Beatriz

Colomina. Sexuality \& Space Ed. Colomina, Beatriz. New York: Princeton

Architectural Press, 1992. 87

Figure 5.6: Moller House

Authors own image

Figure 5.7: Farnsworth House entrance

Miller, Jon. Farnsworth House. "Photos." Plano, IL: National Trust for

Historic Preservation, n.d. 1 June 2011.

<http://www.farnsworthhouse.org/photos.htm>

Figure 5.8: Position to ground

Miller, Jon. Farnsworth House. "Photos." Plano, LL: National Trust for

Historic Preservation, n.d. 1 June 2011.

$$
\text { <http://www.farnsworthhouse.org/photos.htm> }
$$

Figure 5.9: Farnsworth House

Authors own image

Figure 5.10: Slow House conceptual model

Diller, Elizabeth; Socfidio, Ricardo. "Slow House". Diller, Scofidio + Renfro, n.d. 1 June 2011.

$<$ <ttp://www.dsrny.com/>.

Figure 5.11: Connection with view

Diller, Elizabeth; Socfidio, Ricardo. "Slow House". Diller, Scofidio + Renfro, n.d. 1 June 2011.

<http://www.dsrny.com/>

Figure 5.12: Slow House

Authors own imase

Figure 5.13: Picture Window House frame

Ban, Shigeru. “Picture Window House.” Shizuoka: Shigeru Ban, 2002. 1 June

2011

<http://www.shigerubanarchitects.com/SBA_WORKS/SBA

HOUSES/SBA_HOUSES_26/SBA_Houses_26.html>.

Figure 5.14: Open plan ground floor

Ban, Shigeru. “Picture Window House.” Shizuoka: Shigeru Ban, 2002. 1 June

2011

<http://www.shigerubanarchitects.com/SBA_WORKS/SBA

HOUSES/SBA_HOUSES_26/SBA_Houses_26.html>.

Figure 5.15: Picture Window House 
$54 \quad$ Figure 6.2: Current living room

Authors own image

$54 \quad$ Figure 6.3: Current upstairs bedroom

Authors own image

$54 \quad$ Figure 6.4: 45 Orangi Kaupapa Rd

Authors own image

$55 \quad$ Figure 6.5: Street elevation before latest alterations

Herriot + Melhuish: Architecture. "58 Ponsonby Road." Wellington: Herrio + Melhuish: Architecture, n.d.

$55 \quad$ Figure 6.6: Street elevation after latest alterations

Herriot + Melhuish: Architecture. "58 Ponsonby Road" Wellington: Herriot Melhuish: Architecture, n.d.

$56 \quad$ Figure 6.7: View through length of house

Herriot + Melhuish: Architecture. "58 Ponsonby Road." Wellington: Herrio

+ Melhuish: Architecture, n.d.

56 Figure 6.8: 58 Ponsonby Rd

Authors own image

$57 \quad$ Figure 6.9: Living room view

John Mills Architects. "Mills House." Wellington: John Mills Architects, 2004. 12 July 2011.

$$
\text { <http://www.johnmillsarchitects.co.nz/site/main.html> }
$$

57 Figure 6.10: Deck of living room

John Mills Architects. "Mills House." Wellington: John Mills Architects, 2004. 12 July 2011.

$$
\text { <http://www.johnmillsarchitects.co.nz/site/main.htmls. }
$$

57 Figure 6.11: 731 Marine Drive

Authors own image

65 Figure 8.1: View across the sit Authors own image

$65 \quad$ Figure 8.2: Site Map

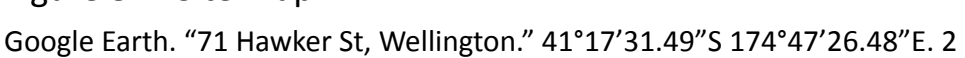
Mar 2009. Google Earth. 29 Oct 2011.

$66 \quad$ Figure 8.3: Heritage restrictions

Authors own image

66 Figure 8.4: Existing building grain

Authors own image

$66 \quad$ Figure 8.5: Site section
Authors own image

Figure 8.6: Site typology

66

Authors own image

Figure 8.7: St Gerard's Church and Monastery 67

Authors own image

Figure 8.8 Existing Villa

Figure 8.9: Access ways

Authors own image

Figure 8.10: Sights

own image

Figure 8.11: Solstice sun path

Authors own image

Figure 9.1: 'In the Southern Alps'

Gully, John. In the Southern Alps. 1881. Museum of New Zealand: Te Papa

Tongarewa, Wellington. “Online Collections." Wellington: Museum of New Zealand, 2009. 1 August 2011.

<http://collections.tepapa.govt.nz/objectdetails.

aspx?oid=36224>.

Figure 9.2: Material Study

Authors own image

Figure 9.3: Development section sketch

Authors own image

Figure 9.4: Development site plan sketch

Figure 9.5: John Gully

Figure 9.6: Sectional perspective

Authors own image

Figure 9.7: Floor plan

Figure 9.8: Thumbnail perspectives

Authors own image

Figure 9.9: 'Mountains, Cass'

Angus, Rita. Mountains, Cass. 1936. Museum of New Zealand: Te Papa

Tongarewa, Wellington. "Online Collections." Wellington: Museum of New Zealand, 2009. 1 August 2011.

$$
\text { <http://collections.tepapa.govt.nz/objectdetails.aspx?oid=41240 }
$$

\&term=mountains $\% 2 c+$ cass $>$.

Figure 9.10: Development section sketch 1 
Authors own image

Figure 9.11: Development section sketch 2

Authors own image

Figure 9.12: Development site plan sketch

Authors own image

Figure 9.13: Rita Angus

Authors own image

Figure 9.14: Sectional perspective

Authors own image

Figure 9.15: Floor plans

Authors own image

Figure 9.16: Thumbnail perspectives

Authors own image

Figure 9.17: 'Silica Zig Zag'

Leenards, Gerda. Silica Zig Zag. 2007. Artis Gallery, Auckland. Auckland: Artist Gallery, n.d. 1 August 2011.

hhttp://www.artisgallery.co.nz/artis_show_image.asp?id=1204〉.

Figure 9.18: Development section sketch 1

Authors own image

79 Figure 9.19: Development section sketch 2 Authors own image

$79 \quad$ Figure 9.20: Development site plan sketch Authors own image

Figure 9.21: Gerda Leenards

Authors own image

Figure 9.22: Sectional perspective

Authors own image

Figure 9.23: Floor plans

Authors own image

ure 9.24: Thumbnail perspectives

Authors own image

Figure 9.25: 'Classic'

Barker, David. Classic. n.d. David Barker, Whangateau. "Now and Then,

2009." David Barker Artist, n.d.

<http://www.davidbarkerartist.com/classic.htm>.

Figure 9.26: Material study

Authors own image

83 Figure 9.27: Development section sketch

Authors own image
Figure 9.28: Development site plan sketch

Authors own image

Figure 9.29: David Barker

Authors own image

Figure 9.30: Sectional perspective

Authors own image

Figure 9.31: Floor plans

Authors own image

Figure 9.32: Thumbnail perspectives

Authors own image

Figure 10.1: Site plan

Authors own image

Figure 10.2: Floor plans

Authors own image

Figure 10.3: Views through interior spaces

Authors own image

Figure 10.4: Single focus

Authors own image

Figure 10.5: Level changes

Authors own image

Figure 10.6: Elongating thresholds

Authors own image

Figure 10.7: Slowing down movement

Authors own image

Figure 10.8: Filtering edges

Authors own image

Figure 10.9: Alternate staircase structure

Authors own image

Figure 10.10: Entrance view

Authors own image

Figure 10.11: View of kitchen to living room

Authors own image

Figure 10.12: Alternate window height

Authors own image

Figure 10.13: Window details

Authors own image

Figure 10.14: View of living room to outside

Authors own image
85

85

94

94 
Figure 10.15: Four points of view

Authors own image

99 Figure 10.16: Stationary points of view

Authors own image

$100 \quad$ Figure 10.17: Site influence

Authors own image

Figure 10.18: Inward focus

Authors own image

Figure 10.19: Grounded on site

Authors own image

igure 10.20: Encouragement of movement

Authors own image

Figure 10.21: Multiple points of view

Authors own image

Figure 10.22: Blurring thresholds

Authors own image

Figure 10.23: Plan of covered outside walkway

Authors own image

Figure 10.24: Window detail

Authors own image

Figure 10.25: View of front and deck

Authors own image

Figure 10.26: Alternate door framing

Authors own image

103 Figure 10.27: View of living room and courtyard

Authors own image

Figure 10.28: Movement paths

Authors own image

Figure 10.29: Level of enclosure

Authors own image

Figure 10.30: Section through House One

Authors own image

Figure 10.31: Section through House Two

Authors own image 


\section{Bibliography}

\section{Works Cited}

Abbott, Mick; Janet, Stephenson, and Ruru, Jacinta. Beyond the Scene. Dunedin: Otago University Press, 2010.

Anderson, Laurie. Scanning: The Aberrant Architectures of Diller + Scofidio New York Whitney Museum of American Art 2003.

Anonymous. "Corseaux-Vevey: La Petite Maison: Le Corbusier in Svizzera." Abitare (1982): 6-9.

Anonymous. "Evolution or Revolution: What New Zealand Architects Are Doing with Modernism." New Dreamland: Writing New Zealand Architecture Ed. Lloyd-Jenkins, Douglas. Auckland: Godwit, 2005. 7982.

Baillieu, Amanda. Contemporary Windows. London: Mitchell Beazley, 2003

Barker, David. David Barker: The Man and His Art. Auckland: David Bateman, 1982.

---. "The Land the Journey". 2010. n.p. 11 August 2011. <http://www.davidbarkerartist.com/ludbrook.htm>.

Blum, Shirley Neilsen. Henri Matisse. London: Thames and Hudson Ltd, 2010.

Bowring, Jacky. “Who Framed the New Zealand Landscape?” The 
Landscape (1994): 7-10.

Campbell, Suzie. "The Landscape Observed: The Art of David Barker." Art New Zealand 106. Autumn (2003): 50-53.

Caughey, Liz. "Gerda Leenards". 2011. NZ Artists. 5th August 2011. <http://nz-artists.co.nz/artists/leenards/>.

Wellington City Art Gallery. "Gerda Leenards: Fjords, Mist \& Vapour". Wellington, 2003. Wellington City Art Gallery. 5th August 2011. $<$ http://citygallery.org.nz/GerdaLeenards/>.

Collins, Damian, and Robin Kearns. “Uninterrupted Views: Real-Estate Advertising and Changing Perspectives on Coastal Property in New Zealand." Environment and Planning 40 (2008): 2914-32.

Colomina, Beatriz. "The Split Wall: Domestic Voyeurism." Sexuality \& Space Ed. Colomina, Beatriz. New York: Princeton Architectural Press, 1992. 73-130.

Crandell, Gina Nature Pictorialized. Harrisonburg, Virginia: John Hopkins University Press, 1993.

Crossan, Diana and Pitches, Neale. Personal interview. 15 June. 2011.

Diller, Elizabeth and Socfidio, Ricardo. "Reviewing." Columbic documents of architecture and theory 1 (1992): 29-51.

Friedberg, Anne. The Virtual Window. Cambridge: Massachusetts Institute of Technology, 2006.

Gatley, Julia. Group Architects: Towards a New Zealand Architecture Ed. Gatley, Julia. Auckland, N.Z.: School of Architecture and Planning, University of Auckland, 2010.

Gottlieb, Carla. The Window in Art: From the Window of God to the Vanity of Man. New York: Abaris Books, 1981

Gully, John Sidney. New Zealand's Romantic Landscape: Paintings by John Gully Ed. Gully, John. Wellington: Millwood, 1984.
Hannah, Dorita. "Architecture as Stage." Exquisite Apart:100 Years of Architecture in New Zealand Ed. Walker, Charles. Auckland: Balasoglou Books on behalf of the New Zealand Institute of Architects, 2005. 183-93.

Heerwagen, Judith; Orians, Gordon. "Adaptations to Windowless: A Study of the Use of Visual Decor in Windowed and Windowless Offices." Environment and Behaviour 18 (1986): 623-39.

Herrington, Susan. "Framed Again: The Picturesque Aesthetics of Contemporary Landscapes.” Landscape Journal 25.1 (2006): 22-37.

Incerti, Guido. Diller + Scofidio (+ Renfro), the Ciliary Function: Works and Projects, 1979-2007. Milan: Skira, 2007.

Isenstadt, Sandy. The Modern American House. New York: Cambridge University Press, 2006.

--.. "Four Views, Three of Them through Glass." Sites Unseen. Ed. Ruggles, Dianne and Fairchild, Harris D. Pittsburgh: University of Pittsburgh, 2007. 213-40

Johnstone, Christopher. Landscape Paintings of New Zealand: A Journey from North to South. Auckland, N.Z: Godwit, 2006.

Jones, Gerald E. "How Houses May Be Improved: A Plea for Art in House Design." New Dreamland: Writing New Zealand Architecture Ed. Lloyd-Jenkins, Douglas. Auckland: Godwit, 2005. 29-46.

Kaplan, Rachel. "The Role of Nature in the Context of the Workplace." Landscape and Urban Planning 26 (1993): 193-201

---. "The Nature of the View from Home, Psychological Benefits." Environment and Behavior (2001): 507-42.

Kaplan, Rachel; Kaplan, Stephen. The Experience of Nature: A Psychological Perspective Cambridge: Cambridge University Press, 1989.

Kaplan, Stephen. "The Restorative Benefits of Nature: Toward an 
Integrative Framework." Journal of Environmental Psychology 15 (1995): 169-82.

Keep, James P; Inman, M. "Windows in the Intensive Therapy Unit" Anaesthesia 35 (1980): 257-62.

Kenzari, Bechir. "Windows." Built Environment (2005): 38-48.

Kepes, Gyorgy. Language of Vision. Chicago: Paul Theobold and Co, 1961.

La Marche, Jean. "The Space of the Surface." Environment and Planning 33 (2001): 2205-18.

Le Corbusier. Une Petite Maison,1923. 3rd ed. Zurich Editions d'Architecture, 1981.

--.. Precisions on the Present State of Architecture and City Planning Trans. Aujame, Edith Schreiber. Précision Sur Un Etat Présent De L'architecture Et De L'urbanisme. Cambridge, Mass: MIT Press, 1991. Leenards, Gerda. "Coastlines." Lilian Ida Smith Award. Wanganui: The Gallery, 1996.

Lo, Richard. Between Two Worlds : The Window and the Relationship of inside to Outside. Wellington: VUW, 1986.

Lustenberger, Kurt. Adolf Loos. Zurich: Artemis, 1994.

Macarthur, John. The Picturesque. Oxon: Routledge, 2007.

McAloon, William and Trevelyan, Jill. "Rita Angus: Life \& Vision" Rita Angus: Life \& Vision Ed. McAloon, William and Trevelyan, Jill. Wellington: Te Papa Press, 2008. 9-18.

McLean, Fred. John Gully, Painter: A Biography Wellington: F. McLean, 2001.

McQuaid, Matilda. Shigeru Ban. London: Phaidon, 2003.

Melhuish, John. Personal interview. 14 June. 2011.
Mills, John and Mills, Juilet. Personal interview. 1 July. 2011.

Mitchell, David. “New Patterns of Settlement.” Exquisite Apart:100 Years of Architecture in New Zealand Ed. Walker, Charles. Auckland: Balasoglou Books on behalf of the New Zealand Institute of Architects, 2005. 135-41.

Moore, E. O. “A Prison Environment's Effect on Health Care Service Demands." Journal of Environmental Systems 11 (1981): 17-34.

Ocula. "John Gully". Auckland, 2011. Ocula. 1st August 2011. <http://ocula.com/artists/john-gully/>.

Oxford English Dictionary. “View, N". 2010. Oxford University Press. 13 March 2011.

<http://www.oed.com/view/Entry/223303?rskey=Jg2m Da\&result=1\&isAdvanced=false\#eid $>$.

---. “Window, N". 2010. Oxford University Press. 13 March 2011. <http://www.oed.com/view/Entry/229262?rskey=BPw O3f\&result=1\&isAdvanced=false\#teid $>$.

Pascoe, Paul and Hall, Humphrey. "The Modern House." New Dreamland: Writing New Zealand Architecture Ed. Lloyd-Jenkins, Douglas. Auckland: Godwit, 2005. 133-38.

Paul, Janet. "What Makes Rita Angus Different?" 1983. Art New Zealand. 3rd August 2011.

$<$ http://www.art-newzealand.com/Issues21to30/ angus.htm>.

Pirrone, Sergio. “Picture Window House: In Japan Shigeru Ban Opens a Long Window onto the Ocean..." Abitare.433 (2003): 96-105.

Plischke, Ernst Anton. "About Houses." New Dreamland: Writing New Zealand Architecture Ed. Lloyd-Jenkins, Douglas. Auckland: Godwit, 2005. 117-32.

Pollock, Naomi R. “Shigeru Ban Revisits the Idea of a Framed View, 
with Walls That Literally Slide Away, Opening His Picture Window House to the Sea." Architectural Record (2003): 128-33.

Pound, Francis. Frames on the Land. Auckland: William Collins Publishing Ltd, 1983.

--. The Invention of New Zealand: Art and National Identity 19301970. Auckland: Auckland of University, 2009.

Relchlin, Bruno. "For and against the Long Window." Andrea Deplazes. Basel: Bikhauser, 2005. 175-201.

Rowe, Colin and Slutzky, Robert. Transparency Basel: Birkhauser Verlag, 1997.

Scully, Vincent. The Earth, the Temple and the Gods: Greek Sacred Architecture. New Haven: Yale University, 1962.

Sennett, Richard. The Conscience of the Eye. New York: Alfred A. Knopf, 1990.

Statistics New Zealand. "Quick Stats About Mt Victoria West".

Wellington, 2006. New Zealand Government. 10 September 2011. $<$ http://www.stats.govt.nz/

Census/2006CensusHomePage/QuickStats/

AboutAPlace/SnapShot.aspx?tab=Households

\&id $=3573400>$.

Stewart, Keith and Potton, Craig. The Food of Art. Nelson: Craig Potton Publishing, 2000.

Stonyer, Penny and Stonyer, Mark. Personal interview. 13 June. 2011.

Sunwoo, Irene. "Taming the Farnsworth House." Thresholds.31 (2006): 66-75.

Taylor, Andrea; Faber, Kuo; Sullivan, Frances E and William, C. "Views of Nature and Self-Discipline: Evidence from Inner City Children." Journal of Environmental Psychology 21 (2001): 1-15. Print.
Tennessen, Carolyn M and Cimprich, Bernadine. "Views to Nature: Effects on Attention." Journal of Environmental Psychology 16 (1995):

77-85.

Tongarewa, Museum of New Zealand: Te Papa. “John Gully's Watercolours”. Wellington, 1998. Tai Awatea. 1st August 2011.

$<$ http://collections.tepapa.govt.nz/theme.aspx?irn=941>

Tunnard, Christopher. World with a View. New Haven: Yale University Press, 1978.

Ulrich, Roger S. "View through a Window May Influence Recovery from Surgery." Science 224 (1984): 420-21.

Vandenberg, Maritz. Farnsworth House: Ludwig Mies Van Der Rohe Architecture in Detail. London Phaidon Press, 2003.

Wellington City Council. “Residential Area Rules." Wellington District Plan. Wellington: Wellington City Council, 2000

$<$ http://www.wellington.govt.nz/plans/district/

volume1/pdfs/v1chap05pt1.pdf>

---. "Mount Victoria North Character Area Design Guide." Wellington District Plan. 13 July 2011

<http://www.wellington.govt.nz/plans/district/volume2/

pdfs/v2mtvicnorth.pdf>.

Wood, Peter. My Trip to Gisborne Lecture. VUW, Wellington, n.d.

\section{Further reading}

Bryson, Bill. At Home. New York: Doubleday, 2010.

Crary, Jonathan. Techniques of the Observer. Cambridge, MA: October Books, 1990

Cronon, William. "The Trouble with Wilderness; or, Getting Back to Wrong Nature." Uncommon Grounds: Towards Re-Inventing Nature. New York: W.W. Norton \& Co, 1995. 69-90. 
Daish, John. Personal interview. 29 June. 2011.

Dubbini, Renzo Geography of the Gaze. Chicago: The University of Chicago, 2002.

Hill, Jonathan. Occupying Architecture. London: Routledge, 1998.

--.. "Turning a Wall in to a Window." Actions of Architecture. New York: Routledge, 2003. 195-99.

senstadt, Sandy. "The Rise and Fall of the Picture Window." Housing and Dwelling: Perspectives on Modern Domestic Architecture. Ed.

Lane, Barbara Miller. New York: Routledge, 2007. 298-306.

Keats, John. "The Crack in the Picture Window." Housing and

Dwelling: Perspectives on Modern Domestic Architecture. Ed. Lane,

Barbara Miller. New York: Routledge, 2007. 272-80.

McCarthy, Christine. "A Summer Place: Postcolonial Retellings of the

New Zealand Bach “ Jouvert Journal of Postcolonial Studies (1998). 10

August 2010

<http://english.chass.ncsu.edu/jouvert/v2i2/MCCART.HTM>.

Pallasmaa, Juhani. The Eyes of the Skin: Architecture and the Senses.

London: Academy Editions, 1996. 


\section{Appendix 1:}

\section{Diagrams}

\section{Spatial diagrams of a view}

Complete diagrammatic study of spatial conditions influencing a view. Certain diagram sets can be found in Chapters one, two or three when relevant to discussions.
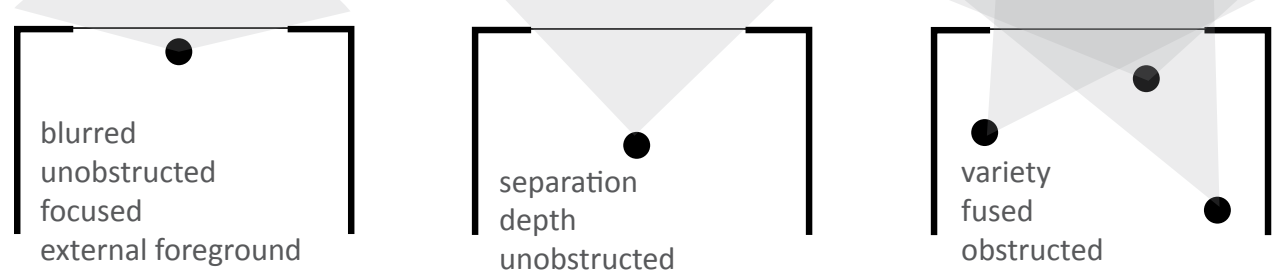

change in viewpoint
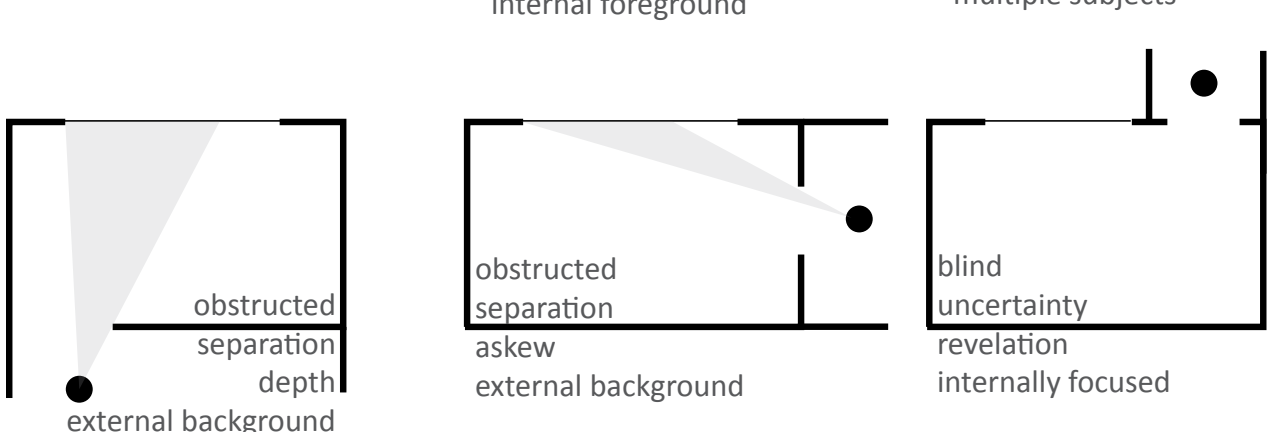

entrance view
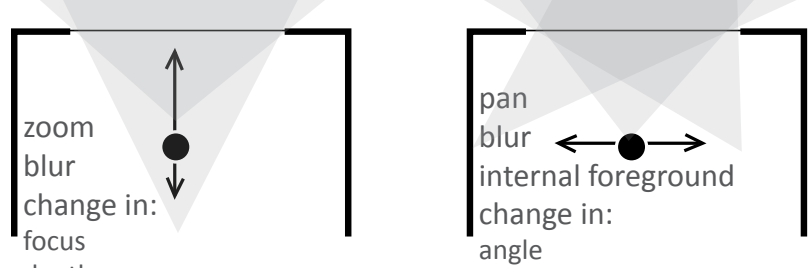

angle

focus

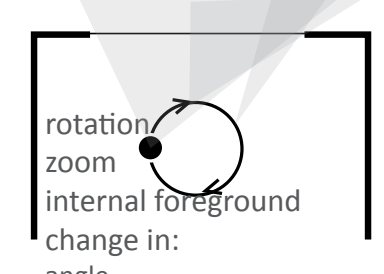

moving

viewpoint 


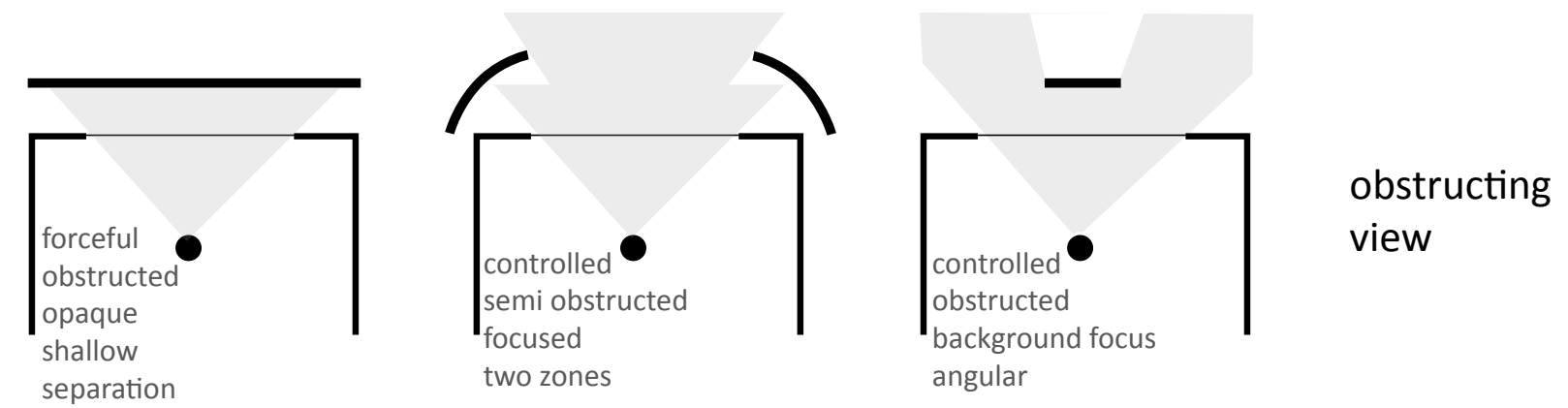

- a ana
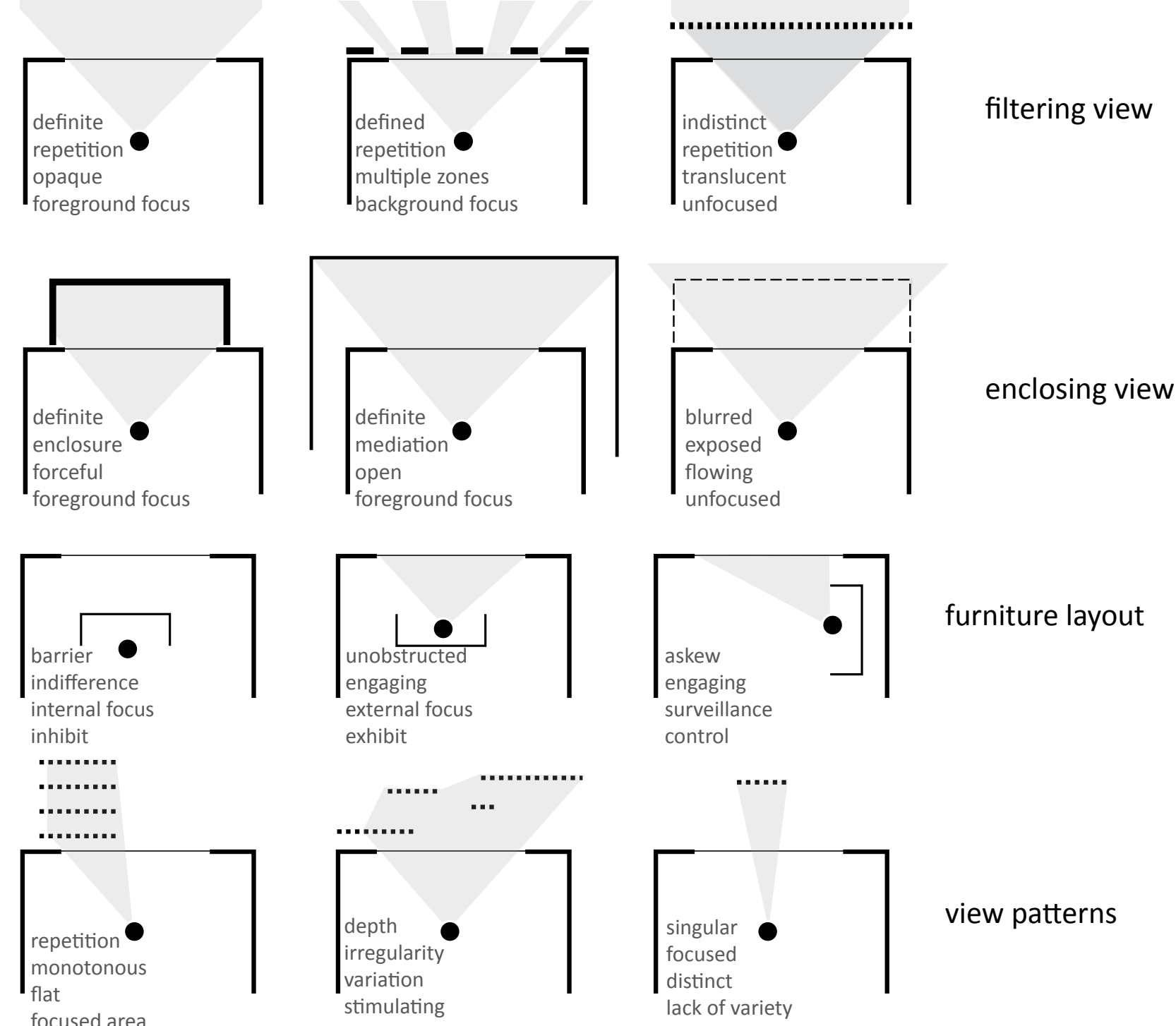
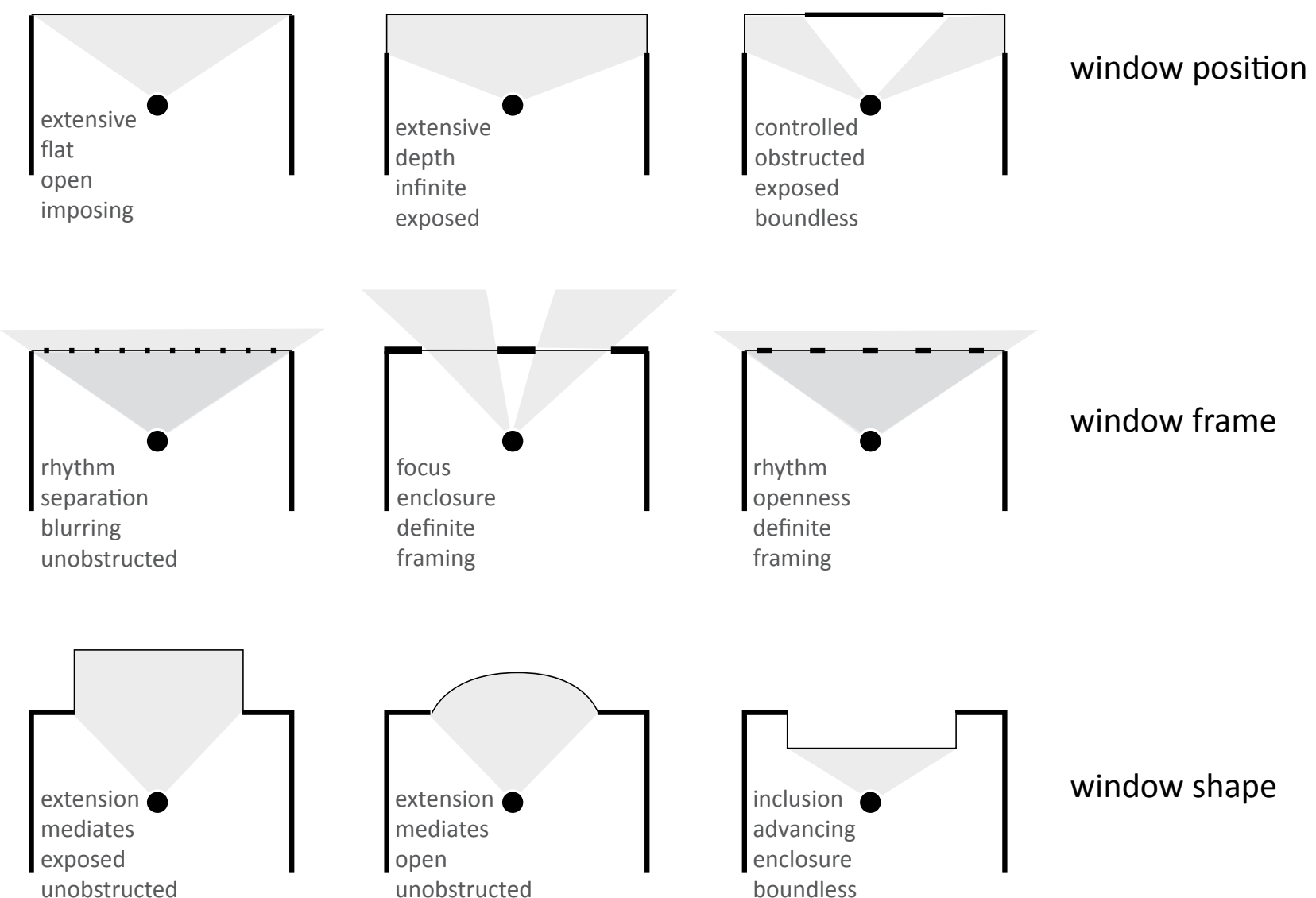

window shape
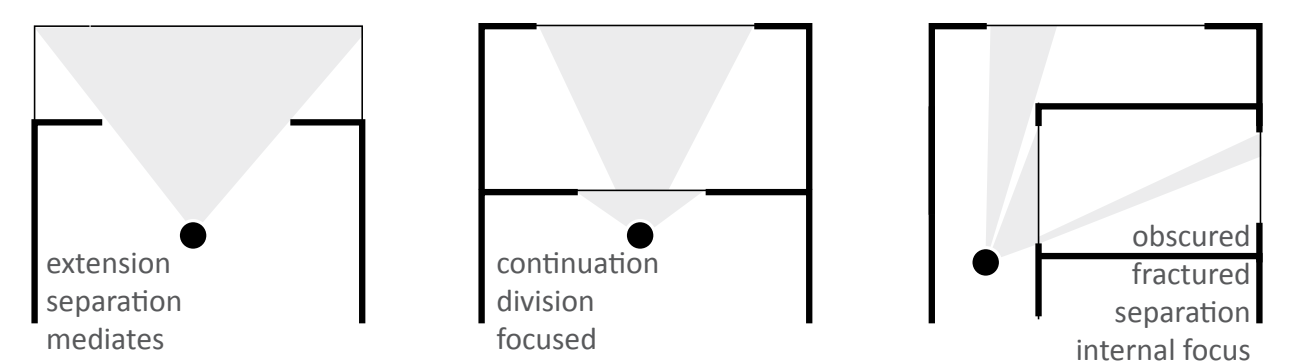

views through rooms

$\begin{array}{ll}\text { mediates } & \text { focused } \\ \text { external background } & \text { external background }\end{array}$

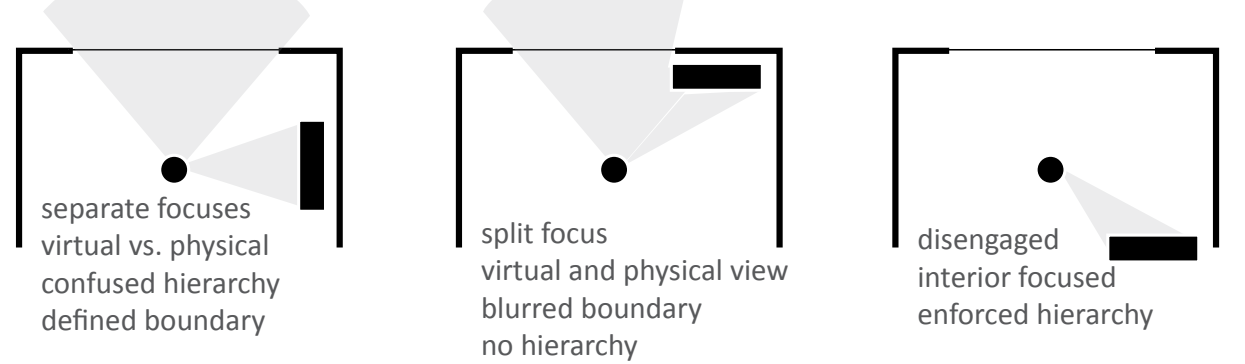

TV versus the view 


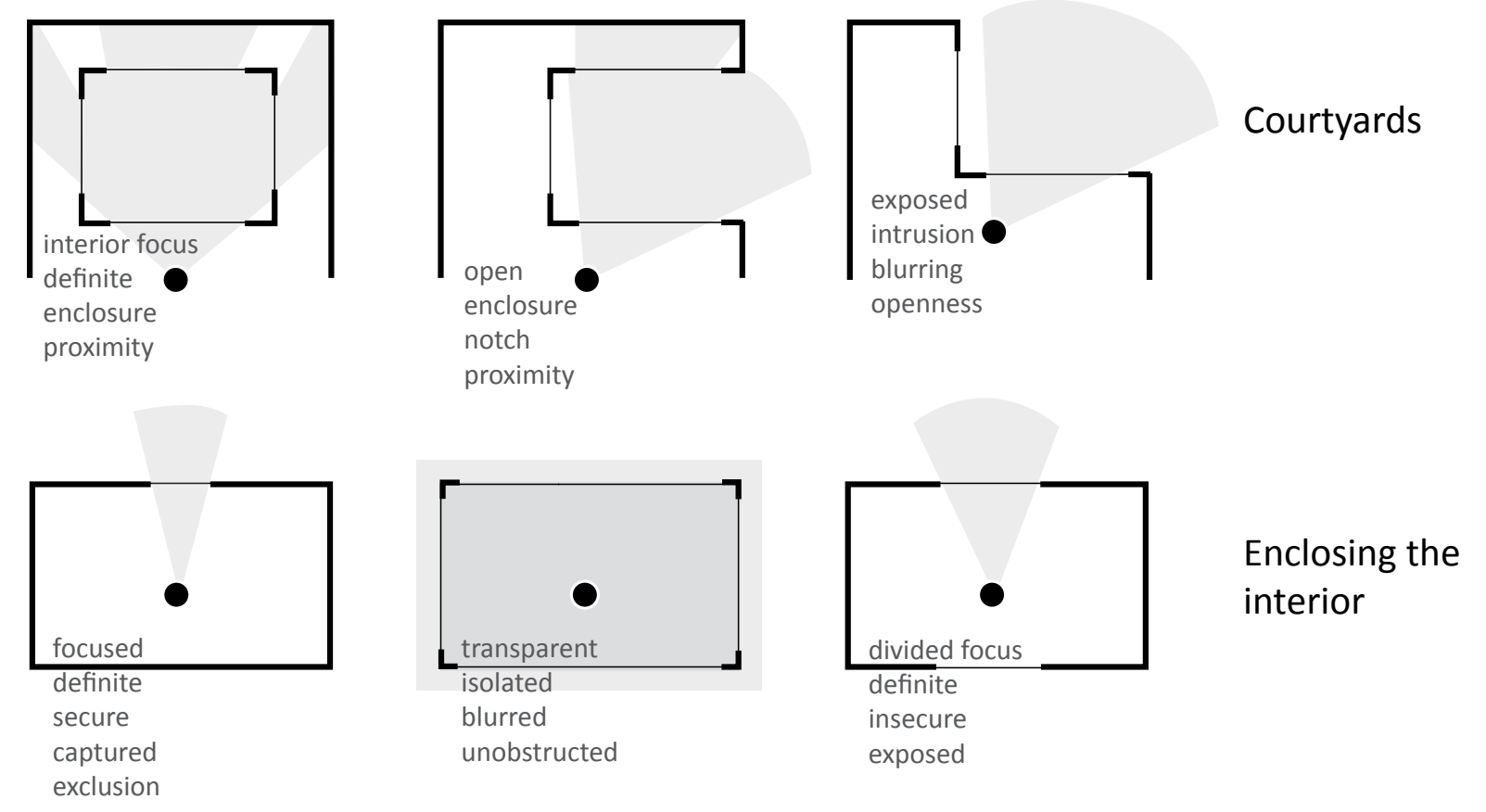

\section{Separation diagrams}

A early diagrammatic study exploring notions of separation and

isolation through built form and material
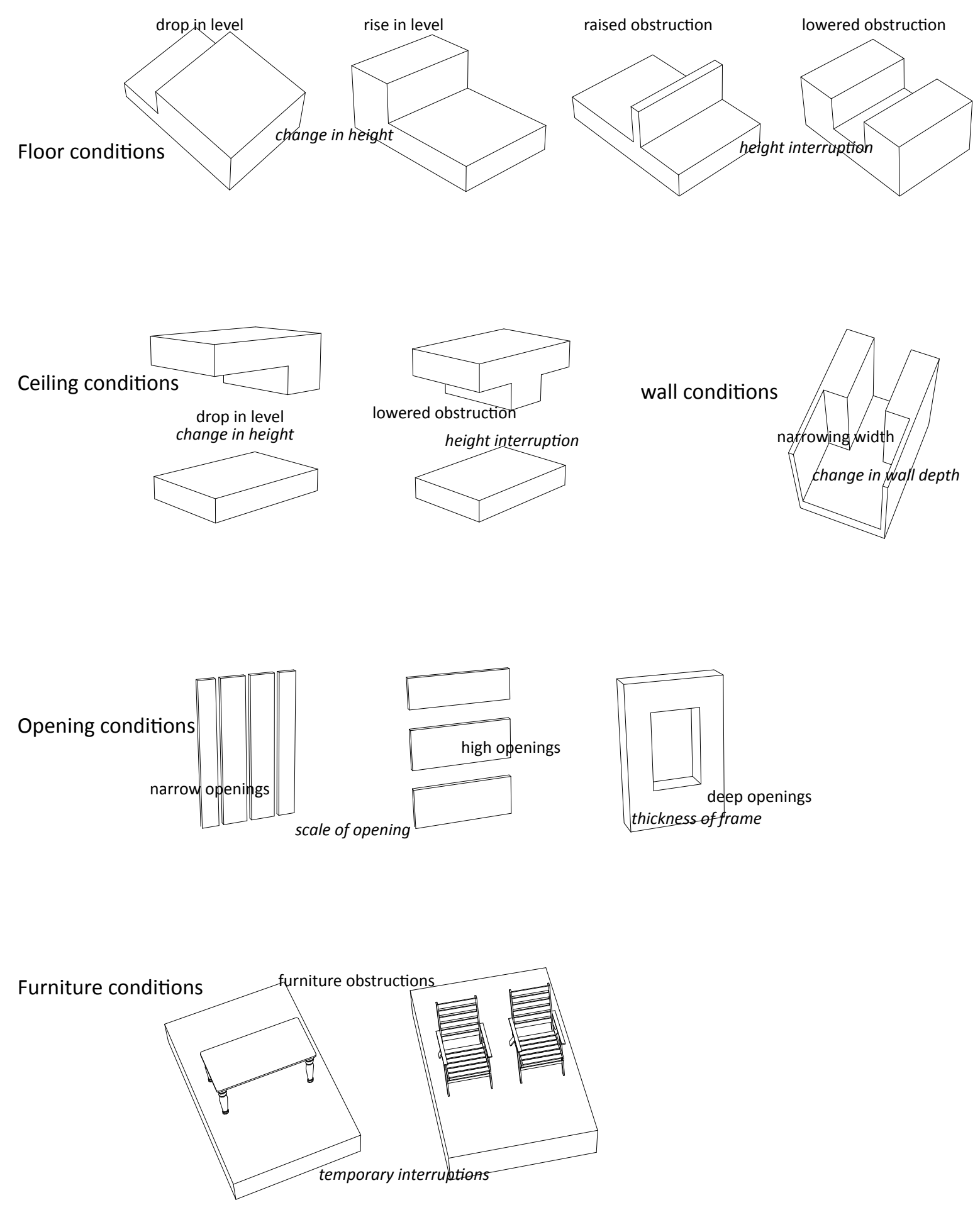

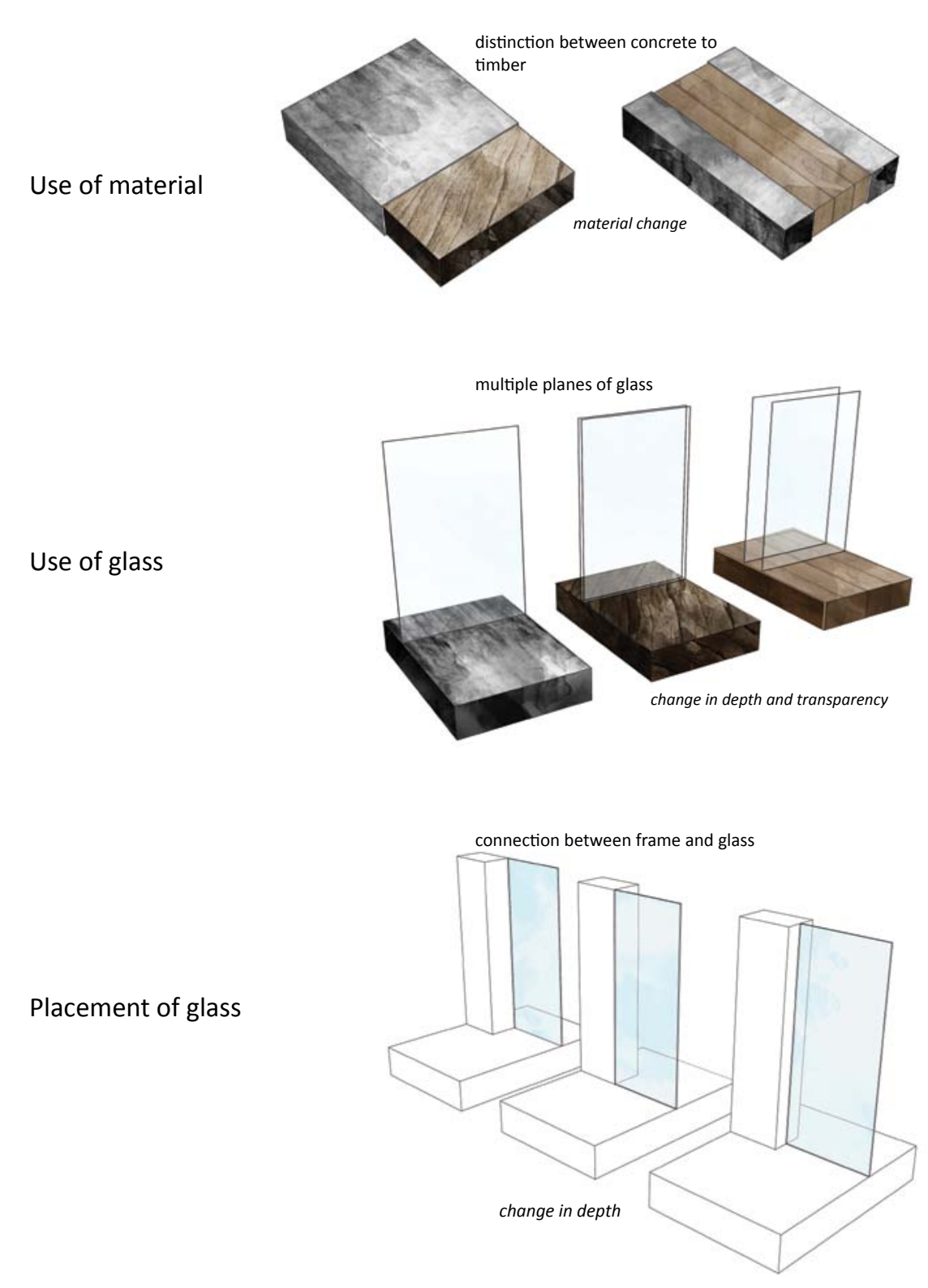

Use of Framing

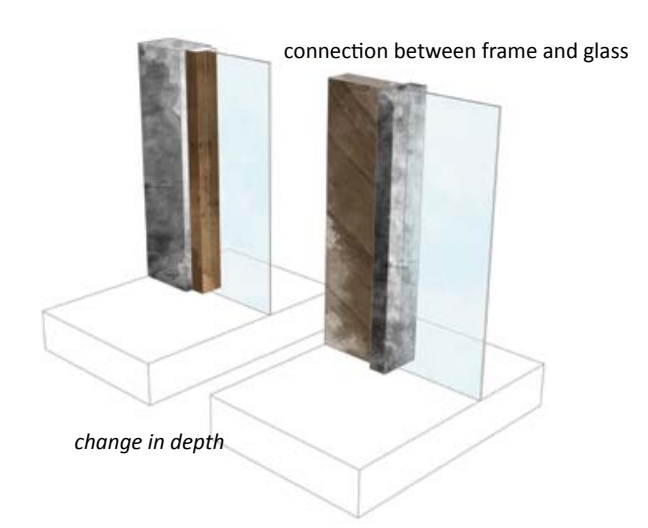




\section{Appendix 2:}

Human Ethics Approval

\section{9}

MEMORANDUM

\begin{tabular}{l|l}
\hline TO & Hester Borren \\
\hline COPY TO & Peter Parkes \\
\hline FROM & Dr Allison Kirkman, Convener, Human Ethics Committee \\
\hline DATE & 29 June 2011 \\
\hline PAGES & 1 \\
\hline \multicolumn{2}{|l}{} \\
\hline SUBJECT & $\begin{array}{l}\text { Ethics Approval: } 18558 \text { - A view of the land: An examination } \\
\text { of New Zealand's architectural relationship to landscape }\end{array}$ \\
\hline
\end{tabular}

Thank you for your application for ethical approval, which has now been considered by the Standing Committee of the Human Ethics Committee.

Your application has been approved from the above date and this approval continues until 20 December 2011 . I your data collecion is not comple by this date you should apply to the Human Ethics Committee for an extension to this approval.

Best wishes with the research.

Allison Kirkman

Human Ethics Committee 


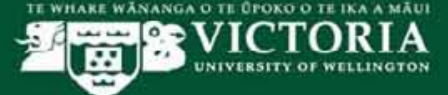

SCHOOL OF ARCHITECTURE Te Kura Waihang

VICTOPA UNY
Phone + 64-4-463 6200 Fax +64-4-463 6204 Email architecture@vuw.ac.nz Web www.victoria.ac..nzlarchitectue

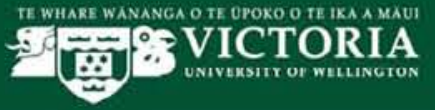

FACULTH

VICTOPA UUNVERSITY OF WELLINGTON, PO Box 600, Wellington 6140 , New Zealan

\section{Questionnaire for occupants and past occupants}

This questionnaire is to be seen as a starting point for discussion on the view from the home. These questions are simply to gauge your attitudes towards the view and how you see it being employed in your house. If you have ideas beyond the specific specific example of your house, please include these. The importance of this questionnaire is to determine what we as New Zealanders we desire from the view/s from our house, how we see it harnessed (the importance of window size and position) and the relationship between the view and the activities, furniture and layout of the rooms of a house. As this thesis is focussed on the changes th have occurred in the New Zealand in the twentieth century, past alterations and the rationale behind them are important as well as future plans or desires for your house.

1. View
1.1 Has the view always been a priority in this house?

1.2 What are the scenes/views that you find the most interesting from your home and

1.2 What are the scenes/views that you find
why? For example, the garden, harbour etc.

1.3 Do you feel you are connected to the outside in your home and how?

\section{Home}

2.1 When do you stop and observe the view in your home? For example, daily, weekly, when you have guests over?

2.2 Which rooms do you feel are enhanced by the view? Is this at all times or for specific activities?

\section{Windows}

3.1 What are your feelings towards the windows in your homes? Do you agree with their placement, proportion and size?

3.2 If you were to rearrange the windows in your house how would you want them? Bigger, smaller, higher? Are these alterations for better daylight, use of space, ventilation, view or for other reasons?

\section{4. $\quad$ Alterations}

4.1 What alterations have you done to you home? And why have you done them?

4.2 How have these alterations improved you home?

4.3 What alterations would you like to do in the future?
Questionnaire for architect or contractor of case study home

This questionnaire is to be seen as a starting point for discussion on the view from the home. These questions are simply to gage your attitudes towards the view and how you see it being employed in the houses you design for. If you have ideas beyond the specific example of your house, please include these. The importance of this questionnaire is to determine what you as New Zealand designers desire from the view/s from our house, how we see it harnessed (the importance of window size and position) and the relationship between the view and the activities, furniture and layout of the rooms of a house. As this thesis is focussed on the changes that have occurred in the New Zealand in the twentieth century, the context of the alteration and the rationale behind it is important as well as future suggestions are important

1. What were the priorities for your client for this project?

2. What priorities did you see for the project?

3. What consideration did you give to the view when designing? How did you prioritise it against other requirements?

4. Did you discuss the view with your client, what were the key points or outcomes of this discussion?

What were the considerations with respect to window placement, proportion and size?

6. Do you agree with the outcome with respect to the view and window?

7. If you got a chance to design this again would you make any changes with respect to the view, window and internal organisation around the view?

8. Was the view a consideration when designing the layout and programme of the house? How was it considered?

9. What do you aim for when detailing windows?

10. Do you see the windows containing / framing the view or in some other way, eg as blurring the inside/outside boundary?

11. Did you consider how the view would be incorporated into the house and the activities that occur within the house? 


\section{SVICTORIA} SCHOOL OF ARCHITECTURE Te Kura Waihanga

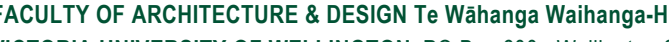

Phone + 64-4-463 6200 Fax +64-4-463 2204 Email architecture@vuw.ac.nz Web www.victoria.ac.nzzlarchitecture

VICTORIA UNIVERSITY OF WELLINGTON

INFORMATION SHEET FOR OCCUPANT

Participant Information Sheet for a Study on the relationship between the view the window and the New Zealand home in the twentieth century

Researcher: Hester Borren: School of Architecture and Design, Victoria University of Wellington

I am an Architecture Masters student at Victoria University of Wellington. As part of this degree I am undertaking a research project leading to a thesis. This project is an examination of the role a view has played in the use of windows and the layout of twentieth New Zealand homes. The University requires that ethics approval be obtained for research involving human participants.

You and your home are one of 10 around the Wellington area helping me determine what New Zealanders desire from view/s from their house, how the view is harnessed (e.g. the importance of window size and position) and the relationship between the view and the activities, furniture and layout of the rooms of a house.

A range of information will be collected including photographs of your house architectural plans (collected from Wellington City Archives unless easily obtainable from you), observations of the houses, and interviews with you, any past occupants of your house and any architects involved.

We have agreed a timeframe for an interview that is at least a week away. This information sheet and questionnaire set out what I will be asking you about. The attached consent form allows you to consider and decide how I can refer to the interview and the information about the house. Please read this material before we meet. It is important you understand the aim of the interview and decide what $I$ can refer to in my report. I will collect the completed form from you when we meet and I am happy to answer further questions then, as needed

The interview will be constructed in two parts. The first will be a tour of your house, where I will take photographs and notes based on my personal

observations. The second part will be a conversation with you about your feelings and attitudes towards your views, aligned with the questionnaire attached.

Responses I collect, both in written and photographic form, will form one of the three key phases of my research project and written report. In order to demonstrate my research findings, I would like to able to refer in my report to dat collected (photographs, plans and descriptions of home and site) and comments you offer. If you do not want to be identified or do not want specific comments

\section{VICTORIA}

SCHOOL OF ARCHITECTURE Te Kura Waihang

quoted in the report or do not want other research material published, please indicate this in the form attached. It is important that you feel comfortable with both the interview process as well as the information that might be in my report. Please advise me of any concerns you have to do with privacy and I will work with you to find an approach in which the essence of the research as well and your privacy can be sustained.

After the interview, you will be offered a chance to see the report as it relates to your contribution and offer feedback on the research collected. If you feel the need to withdraw from the project, or if you want information to be altered, removed or kept confidential, please contact me within a month of receiving the report to discuss this.

The thesis will be submitted for marking to the School of Architecture and Design and deposited in the University Library. All hardcopies of the information collected will be in the custody of my supervisor, Peter Parkes. All other information will remain on my laptop, with password access only. Both hardcopy information and files saved on my laptop will be destroyed at the conclusion of this thesis.

If you have any questions or would like to receive further information about the project, please contact me at:

hester.borren@gmail.com, 0273299105

or my supervisor, Dr Peter Parkes, peterparkes@xtra.co.nz
Hester Borren 


\section{5 : VICTORIA} SCHOOL OF ARCHITECTURE Te Kura Waihanga

VICTORIA UNIVERSITY OF WELLINGTON

INFORMATION SHEET FOR ARCHITECT OR CONTRACTOR

Participant Information Sheet for a Study on the relationship between the view. the window and the New Zealand home in the twentieth century

Researcher: Hester Borren: School of Architecture and Design, Victoria University of Wellington

I am an Architecture Masters student at Victoria University of Wellington. As part of this degree I am undertaking a research project leading to a thesis. This project is an examination of the role a view has played in the use of windows and the layout of twentieth New Zealand homes. The University requires that ethics approval be obtained for research involving human participants.

You and (inserted street address) are one of 10 around the Wellington area helping me determine what New Zealander designers desire from view/s from their house, how the view is harnessed (e.g. the importance of window size and position) and the relationship between the view and the activities, furniture and layout of the rooms of a house.

A range of information will be collected including photographs of your house, A range of information will be collected including photographs of your hous
architectural plans (collected from Wellington City Archives unless easily obtainable from you), observations of the houses, and interviews with you, any past occupants of your house and any architects involved.

We have agreed a timeframe for an interview that is at least a week away. This information sheet and questionnaire set out what I will be asking you about. Th attached consent form allows you to consider and decide how I can refer to the interview and the information about the house. Please read this material before we meet. It is important you understand the aim of the interview and decide what I can refer to in my report. I will collect the completed form from you when we meet and I am happy to answer further questions then, as needed.

The interview will involve a conversation based on the received questionnaire and will be conducted after the interview with the current occupants, within the hou Arll be conduch

Responses I collect, both in written and photographic form, will form one of the three key phases of my research project and written report. In order to

demonstrate my research findings, I would like to able to refer in my report to data collected (photographs, plans and descriptions of home and site) and comments you offer. If you do not want to be identified or do not want specific comments quoted in the report or do not want other research material published, please

\section{S.:- VICTORIA}

SCHOOL OF ARCHITECTURE Te Kura Waihang x 600, Wellington 6140, New Zealan

indicate this in the form attached. It is important that you feel comfortable with Please advise me of any concerns you have to do with privacy and I will work with you to find an approach in which the essence of the research as well and your privacy can be sustained.

After the interview, you will be offered a chance to see the report as it relates to your contribution and offer feedback on the research collected. If you feel the need to withdraw from the project, or if you want information to be altered, removed or kept confidential, please contact me within a month of receiving the report to discuss this

The thesis will be submitted for marking to the School of Architecture and Design and deposited in the University Library. All hardcopies of the information collected will be in the custody of my supervisor, Peter Parkes. All other information will remain on my laptop, with password access only. Both hardcopy information and files saved on my laptop will be destroyed at the conclusion of this thesis. If you have any questions or would like to receive further information about the project, please contact me at:

hester.borren@gmail.com, 0273299105 or my supervisor, Dr Peter Parkes, peterparkes@xtra.co.nz

Hester Borren 